\title{
Chemokine receptors (version 2019.5) in the IUPHAR/BPS Guide to Pharmacology Database
}

\author{
Francoise Bachelerie ${ }^{1}$, Adit Ben-Baruch ${ }^{2}$, Israel F. Charo ${ }^{3}$, Christophe Combadiere ${ }^{4}$, Reinhold Förster ${ }^{5}$, Joshua \\ M. Farber ${ }^{6}$, Gerard J. Graham ${ }^{7}$, Rebecca Hills ${ }^{8}$, Richard Horuk ${ }^{9}$, Massimo Locati ${ }^{10}$, Andrew D. Luster ${ }^{11}$, Alberto \\ Mantovani $^{10}$, Kouji Matsushima ${ }^{12}$, Amy E. Monaghan ${ }^{8}$, Georgios L. Moschovakis ${ }^{5}$, Philip M. Murphy ${ }^{13}$, Robert J. \\ B. Nibbs ${ }^{7}$, Hisayuki Nomiyama ${ }^{14}$, Joost J. Oppenheim ${ }^{15}$, Christine A. Power ${ }^{16}$, Amanda E. I. Proudfoot ${ }^{16}$, Mette \\ M. Rosenkilde ${ }^{17}$, Antal Rot ${ }^{18}$, Silvano Sozzani ${ }^{19}$, Marcus Thelen ${ }^{20}$, Mohib Uddin ${ }^{21}$, Osamu Yoshie ${ }^{22}$ and Albert \\ Zlotnik $^{23}$
}

1. Institut Pasteur, France

2. Tel Aviv University, Israel

3. Gladstone Institutes, USA

4. INSERM, France

5. Hannover Medical School, Germany

6. National Institute of Allergy and Infectious Diseases, USA

7. University of Glasgow, UK

8. University of Edinburgh, UK

9. Berlex Laboratories, USA

10. University of Milan, Italy

11. Massachusetts General Hospital, USA

12. University of Tokyo, Japan

13. National Institutes of Health, USA

14. Kumamoto University Graduate School of Medical Sciences, Japan

15. Frederick National Laboratory for Cancer Research, USA

16. Merck Serono Geneva Research Center, Switzerland

17. Panum Instituttet, Denmark

18. University of Birmingham, UK

19. University of Brescia, Italy

20. Institute for Research in Biomedicine, Switzerland

21. AstraZeneca, Sweden

22. Kinki University, Japan

23. University of California Irvine, USA

\begin{abstract}
Chemokine receptors (nomenclature as agreed by the NC-IUPHAR Subcommittee on Chemokine

Receptors [426, 425, 32]) comprise a large subfamily of 7TM proteins that bind one or more chemokines, a large family of small cytokines typically possessing chemotactic activity for leukocytes. Additional hematopoietic and non-hematopoietic roles have been identified for many chemokines in the areas of embryonic development, immune cell proliferation, activation and death, viral infection, and as antibiotics, among others. Chemokine receptors can be divided by function into two main groups: $G$ protein-coupled chemokine receptors, which mediate leukocyte trafficking, and "Atypical chemokine receptors", which may signal through non-G proteincoupled mechanisms and act as chemokine scavengers to downregulate inflammation or shape chemokine gradients [32].
\end{abstract}

Chemokines in turn can be divided by structure into four subclasses by the number and arrangement of conserved cysteines. CC (also known as $\beta$-chemokines; $n=28$ ), CXC (also known as $\alpha$-chemokines; $n=17$ ) and 
CX3C $(n=1)$ chemokines all have four conserved cysteines, with zero, one and three amino acids separating the first two cysteines respectively. C chemokines $(n=2)$ have only the second and fourth cysteines found in other chemokines. Chemokines can also be classified by function into homeostatic and inflammatory subgroups. Most chemokine receptors are able to bind multiple high-affinity chemokine ligands, but the ligands for a given receptor are almost always restricted to the same structural subclass. Most chemokines bind to more than one receptor subtype. Receptors for inflammatory chemokines are typically highly promiscuous with regard to ligand specificity, and may lack a selective endogenous ligand. G protein-coupled chemokine receptors are named acccording to the class of chemokines bound, whereas ACKR is the root acronym for atypical chemokine receptors [33]. There can be substantial cross-species differences in the sequences of both chemokines and chemokine receptors, and in the pharmacology and biology of chemokine receptors. Endogenous and microbial non-chemokine ligands have also been identified for chemokine receptors. Many chemokine receptors function as HIV co-receptors, but CCR5 is the only one demonstrated to play an essential role in HIV/AIDS pathogenesis. The tables include both standard chemokine receptor names [675] and aliases.

\section{Contents}

This is a citation summary for Chemokine receptors in the Guide to Pharmacology database (GtoPdb). It exists purely as an adjunct to the database to facilitate the recognition of citations to and from the database by citation analyzers. Readers will almost certainly want to visit the relevant sections of the database which are given here under database links.

GtoPdb is an expert-driven guide to pharmacological targets and the substances that act on them. GtoPdb is a reference work which is most usefully represented as an on-line database. As in any publication this work should be appropriately cited, and the papers it cites should also be recognized. This document provides a citation for the relevant parts of the database, and also provides a reference list for the research cited by those parts.

Please note that the database version for the citations given in GtoPdb are to the most recent preceding version in which the family or its subfamilies and targets were substantially changed. The links below are to the current version. If you need to consult the cited version, rather than the most recent version, please contact the GtoPdb curators.

\section{Database links}

\section{Chemokine receptors}

http://www.guidetopharmacology.org/GRAC/FamilyDisplayForward?familyld=14

Introduction to Chemokine receptors

http://www.guidetopharmacology.org/GRAC/FamilyIntroductionForward?familyld=14

Receptors

CCR1

http://www.guidetopharmacology.org/GRAC/ObjectDisplayForward?objectld=58

CCR2

http://www.guidetopharmacology.org/GRAC/ObjectDisplayForward?objectld=59

\section{CCR3}

http://www.guidetopharmacology.org/GRAC/ObjectDisplayForward?objectld=60 CCR4

http://www.guidetopharmacology.org/GRAC/ObjectDisplayForward?objectld=61 CCR5

http://www.guidetopharmacology.org/GRAC/ObjectDisplayForward?objectld=62 CCR6

http://www.guidetopharmacology.org/GRAC/ObjectDisplayForward?objectld=63 CCR7

http://www.guidetopharmacology.org/GRAC/ObjectDisplayForward?objectld=64 CCR8

http://www.guidetopharmacology.org/GRAC/ObjectDisplayForward?objectld=65 CCR9

http://www.guidetopharmacology.org/GRAC/ObjectDisplayForward?objectld=66 CCR10 
http://www.guidetopharmacology.org/GRAC/ObjectDisplayForward?objectld=67 CXCR1

http://www.guidetopharmacology.org/GRAC/ObjectDisplayForward?objectld=68 CXCR2

http://www.guidetopharmacology.org/GRAC/ObjectDisplayForward?objectld=69 CXCR3

http://www.guidetopharmacology.org/GRAC/ObjectDisplayForward?objectld=70 CXCR4

http://www.guidetopharmacology.org/GRAC/ObjectDisplayForward?objectld=71 CXCR5

http://www.guidetopharmacology.org/GRAC/ObjectDisplayForward?objectld=72 CXCR6

http://www.guidetopharmacology.org/GRAC/ObjectDisplayForward?objectld=73 $\mathrm{CX}_{3} \mathrm{CR} 1$

http://www.guidetopharmacology.org/GRAC/ObjectDisplayForward?objectld=74 XCR1

http://www.guidetopharmacology.org/GRAC/ObjectDisplayForward?objectld=75 ACKR1

http://www.guidetopharmacology.org/GRAC/ObjectDisplayForward?objectld=316 ACKR2

http://www.guidetopharmacology.org/GRAC/ObjectDisplayForward?objectld=314 ACKR3

http://www.guidetopharmacology.org/GRAC/ObjectDisplayForward?objectld=80 ACKR4

http://www.guidetopharmacology.org/GRAC/ObjectDisplayForward?objectld=315

CCRL2

http://www.guidetopharmacology.org/GRAC/ObjectDisplayForward?objectld=78

\section{References}

1. Abbadie C, Lindia JA, Cumiskey AM, Peterson LB, Mudgett JS, Bayne EK, DeMartino JA, Maclntyre DE and Forrest MJ. (2003) Impaired neuropathic pain responses in mice lacking the chemokine receptor CCR2. Proc. Natl. Acad. Sci. U.S.A. 100: 7947-52 [PMID:12808141]

2. Abeywardane A, Caviness G, Choi Y, Cogan D, Gao A, Goldberg D, Heim-Riether A, Jeanfavre D, Klein E and Kowalski JA et al.. (2016) N-Arylsulfonyl-a-amino carboxamides are potent and selective inhibitors of the chemokine receptor CCR10 that show efficacy in the murine DNFB model of contact hypersensitivity. Bioorg. Med. Chem. Lett. 26: 5277-5283 [PMID:27692854]

3. Abonia JP, Austen KF, Rollins BJ, Joshi SK, Flavell RA, Kuziel WA, Koni PA and Gurish MF. (2005) Constitutive homing of mast cell progenitors to the intestine depends on autologous expression of the chemokine receptor CXCR2. Blood 105: 4308-13 [PMID:15705791]

4. Adams JL, Smothers J, Srinivasan R and Hoos A. (2015) Big opportunities for small molecules in immunooncology. Nat Rev Drug Discov14: 603-22 [PMID:26228631]

5. Addison CL, Daniel TO, Burdick MD, Liu H, Ehlert JE, Xue YY, Buechi L, Walz A, Richmond A and Strieter RM. (2000) The CXC chemokine receptor 2, CXCR2, is the putative receptor for ELR+ CXC chemokineinduced angiogenic activity. J. Immunol. 165: 5269-77 [PMID:11046061]

6. Adlere I, Sun S, Zarca A, Roumen L, Gozelle M, Perpina CV, Caspar B, Arimont M, Bebelman JP and Briddon SJ et al.. (2018) Structure-based exploration and pharmacological evaluation of $\mathrm{N}$-substituted piperidin-4-yl-methanamine CXCR4 chemokine receptor antagonists European Journal of Medicinal Chemistry 162: 631-649

7. Ahmadi Z, Hassanshahi G, Khorramdelazad H, Zainodini N and Koochakzadeh L. (2016) An Overlook to the Characteristics and Roles Played by Eotaxin Network in the Pathophysiology of Food Allergies: Allergic Asthma and Atopic Dermatitis. Inflammation 39: 1253-67 [PMID:26861136]

8. Ahuja SK and Murphy PM. (1996) The CXC chemokines growth-regulated oncogene (GRO) alpha, GRObeta, GROgamma, neutrophil-activating peptide-2, and epithelial cell-derived neutrophil-activating peptide-78 are potent agonists for the type B, but not the type A, human interleukin-8 receptor. J. Biol. Chem. 271: 20545-50 [PMID:8702798]

9. Ai LS and Liao F. (2002) Mutating the four extracellular cysteines in the chemokine receptor CCR6 reveals their differing roles in receptor trafficking, ligand binding, and signaling. Biochemistry 41: 8332-41 
[PMID:12081481]

10. Ajuebor MN, Aspinall Al, Zhou F, Le T, Yang Y, Urbanski SJ, Sidobre S, Kronenberg M, Hogaboam CM and Swain MG. (2005) Lack of chemokine receptor CCR5 promotes murine fulminant liver failure by preventing the apoptosis of activated CD1d-restricted NKT cells. J. Immunol. 174: 8027-37 [PMID:15944310]

11. Aksoy MO, Yang Y, Ji R, Reddy PJ, Shahabuddin S, Litvin J, Rogers TJ and Kelsen SG. (2005) CXCR3 Surface Expression in Human Airway Epithelial Cells: Cell Cycle Dependence and Effect on Cell Proliferation. Am J Physiol Lung Cell Mol Physiol - [PMID:16339779]

12. Al-Aoukaty A, Rolstad B, Giaid A and Maghazachi AA. (1998) MIP-3alpha, MIP-3beta and fractalkine induce the locomotion and the mobilization of intracellular calcium, and activate the heterotrimeric $G$ proteins in human natural killer cells. Immunology 95: 618-24 [PMID:9893054]

13. Albini A, Ferrini $S$, Benelli R, Sforzini $S$, Giunciuglio D, Aluigi MG, Proudfoot AE, Alouani S, Wells TN and Mariani G et al.. (1998) HIV-1 Tat protein mimicry of chemokines. Proc. Natl. Acad. Sci. U.S.A. 95: 13153-8 [PMID:9789057]

14. Albright AV, Shieh JT, Itoh T, Lee B, Pleasure D, O'Connor MJ, Doms RW and González-Scarano F. (1999) Microglia express CCR5, CXCR4, and CCR3, but of these, CCR5 is the principal coreceptor for human immunodeficiency virus type 1 dementia isolates. J. Virol.73: 205-13 [PMID:9847323]

15. Algood HM and Flynn JL. (2004) CCR5-deficient mice control Mycobacterium tuberculosis infection despite increased pulmonary lymphocytic infiltration. J. Immunol. 173: 3287-96 [PMID:15322191]

16. Allen CD, Ansel KM, Low C, Lesley R, Tamamura H, Fujii N and Cyster JG. (2004) Germinal center dark and light zone organization is mediated by CXCR4 and CXCR5. Nat. Immunol. 5: 943-52 [PMID:15300245]

17. Ambati BK, Anand A, Joussen AM, Kuziel WA, Adamis AP and Ambati J. (2003) Sustained inhibition of corneal neovascularization by genetic ablation of CCR5. Invest Ophthalmol Vis Sci44: 590-593 [PMID:12556387]

18. An P, Li R, Wang JM, Yoshimura T, Takahashi M, Samudralal R, O'Brien SJ, Phair J, Goedert JJ and Kirk GD et al.. (2011) Role of exonic variation in chemokine receptor genes on AIDS: CCRL2 F167Y association with pneumocystis pneumonia. PLoS Genet. 7: e1002328 [PMID:22046140]

19. Andres PG, Beck PL, Mizoguchi E, Mizoguchi A, Bhan AK, Dawson T, Kuziel WA, Maeda N, MacDermott RP and Podolsky DK et al.. (2000) Mice with a selective deletion of the CC chemokine receptors 5 or 2 are protected from dextran sodium sulfate-mediated colitis: lack of CC chemokine receptor 5 expression results in a NK1.1+ lymphocyte-associated Th2-type immune response in the intestine. J. Immunol. 164: 6303-12 [PMID:10843684]

20. Annunziato F, Cosmi L, Santarlasci V, Maggi L, Liotta F, Mazzinghi B, Parente E, Fili L, Ferri S and Frosali F et al.. (2007) Phenotypic and functional features of human Th17 cells.J. Exp. Med. 204: 1849-61 [PMID:17635957]

21. Ansel KM, Ngo VN, Hyman PL, Luther SA, Förster R, Sedgwick JD, Browning JL, Lipp M and Cyster JG. (2000) A chemokine-driven positive feedback loop organizes lymphoid follicles. Nature 406: 309-14 [PMID:10917533]

22. Anton PA, Elliott J, Poles MA, McGowan IM, Matud J, Hultin LE, Grovit-Ferbas K, Mackay CR, Chen ISY and Giorgi JV. (2000) Enhanced levels of functional HIV-1 co-receptors on human mucosal T cells demonstrated using intestinal biopsy tissue. AIDS 14: 1761-5 [PMID:10985313]

23. Antoniu SA. (2010) Mogamulizumab, a humanized mAb against C-C chemokine receptor 4 for the potential treatment of T-cell lymphomas and asthma. Curr. Opin. Mol. Ther. 12: 770-9 [PMID:21154168]

24. Apostolakis S, Baritaki S, Kochiadakis GE, Igoumenidis NE, Panutsopulos D and Spandidos DA. (2007) Effects of polymorphisms in chemokine ligands and receptors on susceptibility to coronary artery disease. Thromb. Res. 119: 63-71 [PMID:16480760]

25. Aramori I, Ferguson SS, Bieniasz PD, Zhang J, Cullen B and Cullen MG. (1997) Molecular mechanism of desensitization of the chemokine receptor CCR-5: receptor signaling and internalization are dissociable from its role as an HIV-1 co-receptor. EMBO J. 16: 4606-16 [PMID:9303305]

26. Auer J, Bläss M, Schulze-Koops H, Russwurm S, Nagel T, Kalden JR, Röllinghoff M and Beuscher HU. (2007) Expression and regulation of CCL18 in synovial fluid neutrophils of patients with rheumatoid arthritis. Arthritis Res. Ther. 9: R94 [PMID:17875202]

27. Auer PL, Teumer A, Schick U, O'Shaughnessy A, Lo KS, Chami N, Carlson C, de Denus S, Dubé MP and Haessler $J$ et al.. (2014) Rare and low-frequency coding variants in CXCR2 and other genes are associated with hematological traits. Nat. Genet. 46: 629-34 [PMID:24777453]

28. Ayehunie S, Garcia-Zepeda EA, Hoxie JA, Horuk R, Kupper TS, Luster AD and Ruprecht RM. (1997) Human immunodeficiency virus-1 entry into purified blood dendritic cells through $\mathrm{CC}$ and $\mathrm{CXC}$ chemokine coreceptors. Blood 90: 1379-86 [PMID:9269754] 
29. Baba M, Imai T, Nishimura M, Kakizaki M, Takagi S, Hieshima K, Nomiyama H and Yoshie O. (1997) Identification of CCR6, the specific receptor for a novel lymphocyte-directed CC chemokine LARC. J. Biol. Chem. 272: 14893-8 [PMID:9169459]

30. Baba M, Nishimura O, Kanzaki N, Okamoto M, Sawada H, lizawa Y, Shiraishi M, Aramaki Y, Okonogi K and Ogawa $Y$ et al.. (1999) A small-molecule, nonpeptide CCR5 antagonist with highly potent and selective anti-HIV-1 activity. Proc. Natl. Acad. Sci. U.S.A. 96: 5698-703 [PMID:10318947]

31. Baba M, Takashima K, Miyake H, Kanzaki N, Teshima K, Wang X, Shiraishi M and lizawa Y. (2005) TAK652 inhibits CCR5-mediated human immunodeficiency virus type 1 infection in vitro and has favorable pharmacokinetics in humans. Antimicrob Agents Chemother 49: 4584-4591 [PMID:16251299]

32. Bachelerie F, Ben-Baruch A, Burkhardt AM, Combadiere C, Farber JM, Graham GJ, Horuk R, SparreUlrich AH, Locati M and Luster AD et al.. (2014) International Union of Pharmacology. LXXXIX. Update on the extended family of chemokine receptors and introducing a new nomenclature for atypical chemokine receptors. Pharmacol. Rev. 66: 1-79 [PMID:24218476]

33. Bachelerie F, Graham GJ, Locati M, Mantovani A, Murphy PM, Nibbs R, Rot A, Sozzani S and Thelen M. (2015) An atypical addition to the chemokine receptor nomenclature: IUPHAR Review 15. Br. J. Pharmacol. 172: 3945-9 [PMID:25958743]

34. Bachem A, Güttler S, Hartung E, Ebstein F, Schaefer M, Tannert A, Salama A, Movassaghi K, Opitz C and Mages HW et al.. (2010) Superior antigen cross-presentation and XCR1 expression define human CD11C+CD141+ cells as homologues of mouse CD8+ dendritic cells. J. Exp. Med. 207: 1273-81 [PMID:20479115]

35. Badewa AP, Hudson CE and Heiman AS. (2002) Regulatory effects of eotaxin, eotaxin-2, and eotaxin-3 on eosinophil degranulation and superoxide anion generation. Exp. Biol. Med. (Maywood) 227: 645-51 [PMID:12192108]

36. Bahl A, Barton P, Bowers K, Brough S, Evans R, Luckhurst CA, Mochel T, Perry MW, Rigby A and Riley RJ et al.. (2012) The discovery of CCR3/H1 dual antagonists with reduced hERG risk.Bioorg. Med. Chem. Lett. 22: 6688-93 [PMID:23031591]

37. Balabanian K, Lagane B, Infantino S, Chow KY, Harriague J, Moepps B, Arenzana-Seisdedos F, Thelen M and Bachelerie F. (2005) The chemokine SDF-1/CXCL12 binds to and signals through the orphan receptor RDC1 in T lymphocytes. J. Biol. Chem. 280: 35760-6 [PMID:16107333]

38. Balabanian K, Lagane B, Pablos JL, Laurent L, Planchenault T, Verola O, Lebbe C, Kerob D, Dupuy A and Hermine $\mathrm{O}$ et al.. (2005) WHIM syndromes with different genetic anomalies are accounted for by impaired CXCR4 desensitization to CXCL12. Blood 105: 2449-57 [PMID:15536153]

39. Bandeira-Melo C, Phoofolo M and Weller PF. (2001) Extranuclear lipid bodies, elicited by CCR3-mediated signaling pathways, are the sites of chemokine-enhanced leukotriene $\mathrm{C} 4$ production in eosinophils and basophils. J. Biol. Chem. 276: 22779-87 [PMID:11274187]

40. Banisadr G, Dicou E, Berbar T, Rostène W, Lombet A and Haour F. (2000) Characterization and visualization of [125I] stromal cell-derived factor-1alpha binding to CXCR4 receptors in rat brain and human neuroblastoma cells. J. Neuroimmunol. 110: 151-60 [PMID:11024545]

41. Banisadr G, Gosselin RD, Mechighel P, Rostène W, Kitabgi P and Mélik Parsadaniantz S. (2005) Constitutive neuronal expression of CCR2 chemokine receptor and its colocalization with neurotransmitters in normal rat brain: functional effect of MCP-1/CCL2 on calcium mobilization in primary cultured neurons. J. Comp. Neurol. 492: 178-92 [PMID:16196033]

42. Banisadr G, Quéraud-Lesaux F, Boutterin MC, Pélaprat D, Zalc B, Rostène W, Haour F and Parsadaniantz SM. (2002) Distribution, cellular localization and functional role of CCR2 chemokine receptors in adult rat brain. J. Neurochem. 81: 257-69 [PMID:12064472]

43. Bao L, Zhu Y, Zhu J and Lindgren JU. (2005) Decreased IgG production but increased MIP-1beta expression in collagen-induced arthritis in C-C chemokine receptor 5-deficient mice. Cytokine 31: 64-71 [PMID:15967376]

44. Barcellos LF, Schito AM, Rimmler JB, Vittinghoff E, Shih A, Lincoln R, Callier S, Elkins MK, Goodkin DE and Haines $\mathrm{JL}$ et al.. (2000) CC-chemokine receptor 5 polymorphism and age of onset in familial multiple sclerosis. Multiple Sclerosis Genetics Group. Immunogenetics 51: 281-8 [PMID:10803840]

45. Bardi G, Lipp M, Baggiolini M and Loetscher P. (2001) The T cell chemokine receptor CCR7 is internalized on stimulation with ELC, but not with SLC. Eur. J. Immunol. 31: 3291-7 [PMID:11745346]

46. Barella L, Loetscher M, Tobler A, Baggiolini M and Moser B. (1995) Sequence variation of a novel heptahelical leucocyte receptor through alternative transcript formation. Biochem. J. 309 ( Pt 3): 773-9 [PMID:7639692]

47. Barnea G, Strapps W, Herrada G, Berman Y, Ong J, Kloss B, Axel R and Lee KJ. (2008) The genetic design of signaling cascades to record receptor activation. Proc. Natl. Acad. Sci. U.S.A. 105: 64-9 
[PMID:18165312]

48. Barr EL, Ouburg S, Igietseme JU, Morré SA, Okwandu E, Eko FO, Ifere G, Belay T, He Q and Lyn Det al.. (2005) Host inflammatory response and development of complications of Chlamydia trachomatis genital infection in CCR5-deficient mice and subfertile women with the CCR5delta32 gene deletion. J Microbiol Immunol Infect 38: 244-54 [PMID:16118671]

49. Barroso R, Martínez Muñoz L, Barrondo S, Vega B, Holgado BL, Lucas P, Baíllo A, Sallés J, RodríguezFrade JM and Mellado M. (2012) EBI2 regulates CXCL13-mediated responses by heterodimerization with CXCR5. FASEB J. 26: 4841-54 [PMID:22913878]

50. Bartoli C, Civatte M, Pellissier JF and Figarella-Branger D. (2001) CCR2A and CCR2B, the two isoforms of the monocyte chemoattractant protein-1 receptor are up-regulated and expressed by different cell subsets in idiopathic inflammatory myopathies. Acta Neuropathol (Berl) 102: 385-392 [PMID:11603815]

51. Beauvillain C, Cunin P, Doni A, Scotet M, Jaillon S, Loiry ML, Magistrelli G, Masternak K, Chevailler A and Delneste $Y$ et al.. (2011) CCR7 is involved in the migration of neutrophils to lymph nodes.Blood 117: 1196204 [PMID:21051556]

52. Belmadani A, Tran PB, Ren D, Assimacopoulos S, Grove EA and Miller RJ. (2005) The chemokine stromal cell-derived factor-1 regulates the migration of sensory neuron progenitors. J. Neurosci. 25: 39954003 [PMID:15843601]

53. Belnoue E, Kayibanda M, Deschemin JC, Viguier M, Mack M, Kuziel WA and Rénia L. (2003) CCR5 deficiency decreases susceptibility to experimental cerebral malaria. Blood 101: 4253-4259 [PMID:12560237]

54. Ben-Baruch A, Grimm M, Bengali K, Evans GA, Chertov O, Wang JM, Howard OM, Mukaida N, Matsushima K and Oppenheim JJ. (1997) The differential ability of IL-8 and neutrophil-activating peptide-2 to induce attenuation of chemotaxis is mediated by their divergent capabilities to phosphorylate CXCR2 (IL-8 receptor B). J. Immunol. 158: 5927-33 [PMID:9190946]

55. Ben-Baruch A, Xu L, Young PR, Bengali K, Oppenheim JJ and Wang JM. (1995) Monocyte chemotactic protein-3 (MCP3) interacts with multiple leukocyte receptors. C-C CKR1, a receptor for macrophage inflammatory protein-1 alpha/Rantes, is also a functional receptor for MCP3. J. Biol. Chem. 270: 22123-8 [PMID:7545673]

56. Benkirane M, Jin DY, Chun RF, Koup RA and Jeang KT. (1997) Mechanism of transdominant inhibition of CCR5-mediated HIV-1 infection by ccr5delta32. J. Biol. Chem. 272: 30603-6 [PMID:9388191]

57. Berahovich RD, Zabel BA, Penfold ME, Lewén S, Wang Y, Miao Z, Gan L, Pereda J, Dias J, Slukvin II, McGrath KE, Jaen JC and Schall TJ. (2010) CXCR7 Protein Is Not Expressed on Human or Mouse Leukocytes. J. Immunol. 185: 5130-9 [PMID:20889540]

58. Berger EA, Doms RW, Fenyö EM, Korber BT, Littman DR, Moore JP, Sattentau QJ, Schuitemaker H, Sodroski J and Weiss RA. (1998) A new classification for HIV-1. Nature 391: 240 [PMID:9440686]

59. Berger EA, Murphy PM and Farber JM. (1999) Chemokine receptors as HIV-1 coreceptors: Roles in viral entry, tropism and disease. Annu. Rev. Immunol. 17: 657-700 [PMID:10358771]

60. Berkhout TA, Blaney FE, Bridges AM, Cooper DG, Forbes IT, Gribble AD, Groot PH, Hardy A, Ife RJ and Kaur $\mathrm{R}$ et al.. (2003) CCR2: characterization of the antagonist binding site from a combined receptor modeling/mutagenesis approach. J. Med. Chem. 46: 4070-86 [PMID:12954060]

61. Bernardini G, Hedrick J, Sozzani S, Luini W, Spinetti G, Weiss M, Menon S, Zlotnik A, Mantovani A and Santoni $A$ et al.. (1998) Identification of the CC chemokines TARC and macrophage inflammatory protein-1 beta as novel functional ligands for the CCR8 receptor. Eur. J. Immunol. 28: 582-8 [PMID:9521068]

62. Bernardini G, Spinetti G, Ribatti D, Camarda G, Morbidelli L, Ziche M, Santoni A, Capogrossi MC and Napolitano M. (2000) I-309 binds to and activates endothelial cell functions and acts as an angiogenic molecule in vivo. Blood 96: 4039-45 [PMID:11110671]

63. Berson JF, Long D, Doranz BJ, Rucker J, Jirik FR and Doms RW. (1996) A seven-transmembrane domain receptor involved in fusion and entry of T-cell-tropic human immunodeficiency virus type 1 strains. J. Virol. 70: 6288-95 [PMID:8709256]

64. Bertini R, Allegretti M, Bizzarri C, Moriconi A, Locati M, Zampella G, Cervellera MN, Di Cioccio V, Cesta $M C$ and Galliera E et al.. (2004) Noncompetitive allosteric inhibitors of the inflammatory chemokine receptors CXCR1 and CXCR2: prevention of reperfusion injury. Proc. Natl. Acad. Sci. U.S.A. 101: 11791-6 [PMID:15282370]

65. Bertini R, Barcelos LS, Beccari AR, Cavalieri B, Moriconi A, Bizzarri C, Di Benedetto P, Di Giacinto C, Gloaguen I and Galliera E et al.. (2012) Receptor binding mode and pharmacological characterization of a potent and selective dual CXCR1/CXCR2 non-competitive allosteric inhibitor. Br. J. Pharmacol. 165: 43654 [PMID:21718305]

66. Biber K, Zuurman MW, Homan H and Boddeke HW. (2003) Expression of L-CCR in HEK 293 cells reveals 
functional responses to CCL2, CCL5, CCL7, and CCL8. J. Leukoc. Biol. 74: 243-51 [PMID:12885941]

67. Bishop B and Lloyd CM. (2003) CC chemokine ligand 1 promotes recruitment of eosinophils but not Th2 cells during the development of allergic airways disease. J. Immunol. 170: 4810-7 [PMID:12707363]

68. Biswas S, Sengupta S, Roy Chowdhury S, Jana S, Mandal G, Mandal PK, Saha N, Malhotra V, Gupta A and Kuprash DV et al.. (2014) CXCL13-CXCR5 co-expression regulates epithelial to mesenchymal transition of breast cancer cells during lymph node metastasis. Breast Cancer Res. Treat. 143: 265-76 [PMID:24337540]

69. Blanchard C, Wang N, Stringer KF, Mishra A, Fulkerson PC, Abonia JP, Jameson SC, Kirby C, Konikoff $\mathrm{MR}$ and Collins $\mathrm{MH}$ et al.. (2006) Eotaxin-3 and a uniquely conserved gene-expression profile in eosinophilic esophagitis. J. Clin. Invest. 116: 536-47 [PMID:16453027]

70. Blanpain C, Migeotte I, Lee B, Vakili J, Doranz BJ, Govaerts C, Vassart G, Doms RW and Parmentier M. (1999) CCR5 binds multiple CC-chemokines: MCP-3 acts as a natural antagonist. Blood 94: 1899-905 [PMID:10477718]

71. Blease K, Mehrad B, Standiford TJ, Lukacs NW, Gosling J, Boring L, Charo IF, Kunkel SL and Hogaboam CM. (2000) Enhanced pulmonary allergic responses to Aspergillus in CCR2-/- mice. J Immuno/ 165: 26032611 [PMID:10946288]

72. Blednov YA, Bergeson SE, Walker D, Ferreira VM, Kuziel WA and Harris RA. (2005) Perturbation of chemokine networks by gene deletion alters the reinforcing actions of ethanol. Behav. Brain Res. 165: 11025 [PMID:16105698]

73. Bleul CC, Farzan M, Choe H, Parolin C, Clark-Lewis I, Sodroski J and Springer TA. (1996) The lymphocyte chemoattractant SDF-1 is a ligand for LESTR/fusin and blocks HIV-1 entry. Nature 382: 829-33 [PMID:8752280]

74. Boislève F, Kerdine-Römer S, Rougier-Larzat N and Pallardy M. (2004) Nickel and DNCB induce CCR7 expression on human dendritic cells through different signalling pathways: role of TNF-alpha and MAPK. J. Invest. Dermatol. 123: 494-502 [PMID:15304089]

75. Boisvert WA, Santiago R, Curtiss LK and Terkeltaub RA. (1998) A leukocyte homologue of the IL-8 receptor CXCR-2 mediates the accumulation of macrophages in atherosclerotic lesions of LDL receptordeficient mice. J. Clin. Invest. 101: 353-63 [PMID:9435307]

76. Bonini JA, Martin SK, Dralyuk F, Roe MW, Philipson LH and Steiner DF. (1997) Cloning, expression, and chromosomal mapping of a novel human CC-chemokine receptor (CCR10) that displays high-affinity binding for MCP-1 and MCP-3. DNA Cell Biol. 16: 1249-56 [PMID:9364936]

77. Boring L, Gosling J, Chensue SW, Kunkel SL, Farese Jr RV, Broxmeyer HE and Charo IF. (1997) Impaired monocyte migration and reduced type 1 (Th1) cytokine responses in C-C chemokine receptor 2 knockout mice. J. Clin. Invest. 100: 2552-61 [PMID:9366570]

78. Boring L, Gosling J, Cleary M and Charo IF. (1998) Decreased lesion formation in CCR2-/- mice reveals a role for chemokines in the initiation of atherosclerosis. Nature 394: 894-7 [PMID:9732872]

79. Bozic CR, Gerard NP, von Uexkull-Guldenband C, Kolakowski Jr LF, Conklyn MJ, Breslow R, Showell HJ and Gerard C. (1994) The murine interleukin 8 type B receptor homologue and its ligands. Expression and biological characterization. J. Biol. Chem. 269: 29355-8 [PMID:7961909]

80. Brand S, Hofbauer K, Dambacher J, Schnitzler F, Staudinger T, Pfennig S, Seiderer J, Tillack C, Konrad A and Göke B et al.. (2006) Increased expression of the chemokine fractalkine in Crohn's disease and association of the fractalkine receptor T280M polymorphism with a fibrostenosing disease Phenotype. Am. J. Gastroenterol. 101: 99-106 [PMID:16405540]

81. Brightling CE, Kaur D, Berger P, Morgan AJ, Wardlaw AJ and Bradding P. (2005) Differential expression of CCR3 and CXCR3 by human lung and bone marrow-derived mast cells: implications for tissue mast cell migration. J. Leukoc. Biol. 77: 759-66 [PMID:15673545]

82. Brodfuehrer J, Rankin A, Edmonds J, Keegan S, Andreyeva T, Lawrence-Henderson R, Ozer J, Gao H, Bloom $L$ and Boisvert A et al.. (2014) Quantitative analysis of target coverage and germinal center response by a CXCL13 neutralizing antibody in a T-dependent mouse immunization model. Pharm. Res. 31: 635-48 [PMID:24190631]

83. Brodmerkel CM, Huber R, Covington M, Diamond S, Hall L, Collins R, Leffet L, Gallagher K, Feldman P and Collier $\mathrm{P}$ et al.. (2005) Discovery and pharmacological characterization of a novel rodent-active CCR2 antagonist, INCB3344. J. Immunol. 175: 5370-8 [PMID:16210643]

84. Brouwer N, Zuurman MW, Wei T, Ransohoff RM, Boddeke HW and Biber K. (2004) Induction of glial LCCR mRNA expression in spinal cord and brain in experimental autoimmune encephalomyelitis. Glia 46: 84-94 [PMID:14999816]

85. Brown MN, Fintushel SR, Lee MH, Jennrich S, Geherin SA, Hay JB, Butcher EC and Debes GF. (2010) Chemoattractant receptors and lymphocyte egress from extralymphoid tissue: changing requirements 
during the course of inflammation. J. Immunol. 185: 4873-82 [PMID:20833836]

86. Broxmeyer HE, Cooper S, Cacalano G, Hague NL, Bailish E and Moore MW. (1996) Involvement of Interleukin (IL) 8 receptor in negative regulation of myeloid progenitor cells in vivo: evidence from mice lacking the murine IL-8 receptor homologue. J. Exp. Med. 184: 1825-32 [PMID:8920870]

87. Brumme ZL, Dong WW, Chan KJ, Hogg RS, Montaner JS, O'Shaughnessy MV and Harrigan PR. (2003) Influence of polymorphisms within the CX3CR1 and MDR-1 genes on initial antiretroviral therapy response. AIDS 17: 201-8 [PMID:12545080]

88. Bryan SA, Jose PJ, Topping JR, Wilhelm R, Soderberg C, Kertesz D, Barnes PJ, Williams TJ, Hansel TT and Sabroe I. (2002) Responses of leukocytes to chemokines in whole blood and their antagonism by novel CC-chemokine receptor 3 antagonists. Am. J. Respir. Crit. Care Med.165: 1602-9 [PMID:12070060]

89. Buanne P, Di Carlo E, Caputi L, Brandolini L, Mosca M, Cattani F, Pellegrini L, Biordi L, Coletti G and Sorrentino $C$ et al.. (2007) Crucial pathophysiological role of CXCR2 in experimental ulcerative colitis in mice. J. Leukoc. Biol. 82: 1239-46 [PMID:17656654]

90. Burger JA and Kipps TJ. (2006) CXCR4: a key receptor in the crosstalk between tumor cells and their microenvironment. Blood 107: 1761-7 [PMID:16269611]

91. Burns JM, Summers BC, Wang Y, Melikian A, Berahovich R, Miao Z, Penfold ME, Sunshine MJ, Littman DR, Kuo CJ, Wei K, McMaster BE, Wright K, Howard MC and Schall TJ. (2006) A novel chemokine receptor for SDF-1 and I-TAC involved in cell survival, cell adhesion, and tumor development. J. Exp. Med. 203: 2201-13 [PMID:16940167]

92. Bäckhed F, Torstensson E, Seguin D, Richter-Dahlfors A and Rokbi B. (2003) Helicobacter pylori infection induces interleukin-8 receptor expression in the human gastric epithelium. Infect. Immun. 71: 3357-60 [PMID:12761119]

93. Bürkle A, Niedermeier M, Schmitt-Gräff A, Wierda WG, Keating MJ and Burger JA. (2007) Overexpression of the CXCR5 chemokine receptor, and its ligand, CXCL13 in B-cell chronic lymphocytic leukemia. Blood 110: 3316-25 [PMID:17652619]

94. Cacalano G, Lee J, Kikly K, Ryan AM, Pitts-Meek S, Hultgren B, Wood WI and Moore MW. (1994) Neutrophil and B cell expansion in mice that lack the murine IL-8 receptor homolog. Science 265: 682-4 [PMID:8036519]

95. Cahn A, Hodgson S, Wilson R, Robertson J, Watson J, Beerahee M, Hughes SC, Young G, Graves R and Hall D et al.. (2013) Safety, tolerability, pharmacokinetics and pharmacodynamics of GSK2239633, a CCchemokine receptor 4 antagonist, in healthy male subjects: results from an open-label and from a randomised study. BMC Pharmacol Toxicol 14: 14 [PMID:23448278]

96. Cairns CM, Gordon JR, Li F, Baca-Estrada ME, Moyana T and Xiang J. (2001) Lymphotactin expression by engineered myeloma cells drives tumor regression: mediation by CD4+ and CD8+ T cells and neutrophils expressing XCR1 receptor. J. Immunol. 167: 57-65 [PMID:11418632]

97. Calderón $L$ and Boehm T. (2011) Three chemokine receptors cooperatively regulate homing of hematopoietic progenitors to the embryonic mouse thymus. Proc. Natl. Acad. Sci. U.S.A. 108: 7517-22 [PMID:21502490]

98. Campbell EM, Charo IF, Kunkel SL, Strieter RM, Boring L, Gosling J and Lukacs NW. (1999) Monocyte chemoattractant protein-1 mediates cockroach allergen-induced bronchial hyperreactivity in normal but not CCR2-/- mice: the role of mast cells. J. Immunol. 163: 2160-7 [PMID:10438957]

99. Campbell JJ, Haraldsen G, Pan J, Rottman J, Qin S, Ponath P, Andrew DP, Warnke R, Ruffing N and Kassam N et al.. (1999) The chemokine receptor CCR4 in vascular recognition by cutaneous but not intestinal memory T cells. Nature 400: 776-80 [PMID:10466728]

100. Campbell JJ, Pan J and Butcher EC. (1999) Cutting edge: developmental switches in chemokine responses during T cell maturation. J. Immunol. 163: 2353-7 [PMID:10452965]

101. Capriotti E, Vonderheid EC, Thoburn CJ, Bright EC and Hess AD. (2007) Chemokine receptor expression by leukemic T cells of cutaneous T-cell lymphoma: clinical and histopathological correlations. J. Invest. Dermatol. 127: 2882-92 [PMID:17597825]

102. Carlsen HS, Baekkevold ES, Johansen FE, Haraldsen G and Brandtzaeg P. (2002) B cell attracting chemokine 1 (CXCL13) and its receptor CXCR5 are expressed in normal and aberrant gut associated lymphoid tissue. Gut 51: 364-71 [PMID:12171958]

103. Carramolino L, Zaballos A, Kremer L, Villares R, Martín P, Ardavín C, Martínez-A C and Márquez G. (2001) Expression of CCR9 beta-chemokine receptor is modulated in thymocyte differentiation and is selectively maintained in CD8(+) T cells from secondary lymphoid organs. Blood 97: 850-7 [PMID:11159507]

104. Carter PH, Brown GD, Cherney RJ, Batt DG, Chen J, Clark CM, Cvijic ME, Duncia JV, Ko SS and Mandlekar S et al.. (2015) Discovery of a Potent and Orally Bioavailable Dual Antagonist of CC 
Chemokine Receptors 2 and 5. ACS Med Chem Lett 6: 439-44 [PMID:25893046]

105. Cartier L, Dubois-Dauphin M, Hartley O, Irminger-Finger I and Krause KH. (2003) Chemokine-induced cell death in CCR5-expressing neuroblastoma cells. J. Neuroimmunol. 145: 27-39 [PMID:14644028]

106. Castellucci L, Jamieson SE, Miller EN, Menezes E, Oliveira J, Magalhães A, Guimarães LH, Lessa M, de Jesus AR and Carvalho EM et al.. (2010) CXCR1 and SLC11A1 polymorphisms affect susceptibility to cutaneous leishmaniasis in Brazil: a case-control and family-based study. BMC Med. Genet. 11: 10 [PMID:20089160]

107. Celis R, Planell N, Fernández-Sueiro JL, Sanmartí R, Ramírez J, González-Álvaro I, Pablos JL and Cañete JD. (2012) Synovial cytokine expression in psoriatic arthritis and associations with lymphoid neogenesis and clinical features. Arthritis Res. Ther. 14: R93 [PMID:22541888]

108. Chan CC, Tuo J, Bojanowski CM, Csaky KG and Green WR. (2005) Detection of CX3CR1 single nucleotide polymorphism and expression on archived eyes with age-related macular degeneration. Histol Histopathol 20: 857-863 [PMID:15944936]

109. Chandrasekar B, Bysani S and Mummidi S. (2004) CXCL16 signals via Gi, phosphatidylinositol 3-kinase, Akt, I kappa B kinase, and nuclear factor-kappa B and induces cell-cell adhesion and aortic smooth muscle cell proliferation. J. Biol. Chem. 279: 3188-96 [PMID:14625285]

110. Chapman DG, Mougey EB, Van der Velden JL, Lahue KG, Aliyeva M, Daphtary N, George KL, Hoffman SM, Schneider RW and Tracy RP et al.. (2017) The Duffy antigen receptor for chemokines regulates asthma pathophysiology. Clin. Exp. Allergy 47: 1214-1222 [PMID:28471517]

111. Charbonneau B, Wang AH, Maurer MJ, Asmann YW, Zent CS, Link BK, Ansell SM, Weiner GJ, Ozsan N and Feldman AL et al.. (2013) CXCR5 polymorphisms in non-Hodgkin lymphoma risk and prognosis. Cancer Immunol. Immunother. 62: 1475-84 [PMID:23812490]

112. Charbonnier AS, Kohrgruber N, Kriehuber E, Stingl G, Rot A and Maurer D. (1999) Macrophage inflammatory protein 3alpha is involved in the constitutive trafficking of epidermal langerhans cells. J. Exp. Med. 190: 1755-68 [PMID:10601351]

113. Charo IF, Myers SJ, Herman A, Franci C, Connolly AJ and Coughlin SR. (1994) Molecular cloning and functional expression of two monocyte chemoattractant protein 1 receptors reveals alternative splicing of the carboxyl-terminal tails. Proc. Natl. Acad. Sci. U.S.A.91: 2752-6 [PMID:8146186]

114. Cheng S, Han L, Guo J, Yang Q, Zhou J and Yang X. (2014) The essential roles of CCR7 in epithelial-tomesenchymal transition induced by hypoxia in epithelial ovarian carcinomas. Tumour Biol. 35: 12293-8 [PMID:25168373]

115. Chensue SW, Lukacs NW, Yang TY, Shang X, Frait KA, Kunkel SL, Kung T, Wiekowski MT, Hedrick JA and Cook DN et al.. (2001) Aberrant in vivo T helper type 2 cell response and impaired eosinophil recruitment in CC chemokine receptor 8 knockout mice. J. Exp. Med. 193: 573-84 [PMID:11238588]

116. Cheong HS, Park CS, Kim LH, Park BL, Uh ST, Kim YH, Lym GI, Lee JY, Lee JK and Kim HTet al.. (2005) CXCR3 polymorphisms associated with risk of asthma. Biochem. Biophys. Res. Commun. 334: 1219-25 [PMID:16043121]

117. Chies JA and Hutz MH. (2003) High frequency of the CCR5delta32 variant among individuals from an admixed Brazilian population with sickle cell anemia. Braz. J. Med. Biol. Res. 36: 71-5 [PMID:12532229]

118. Chiu BC, Freeman CM, Stolberg VR, Hu JS, Zeibecoglou K, Lu B, Gerard C, Charo IF, Lira SA and Chensue SW. (2004) Impaired lung dendritic cell activation in CCR2 knockout mice. Am. J. Pathol. 165: 1199-209 [PMID:15466386]

119. Choe H, Farzan M, Sun Y, Sullivan N, Rollins B, Ponath PD, Wu L, Mackay CR, LaRosa G and Newman W et al.. (1996) The beta-chemokine receptors CCR3 and CCR5 facilitate infection by primary HIV-1 isolates. Cell 85: 1135-48 [PMID:8674119]

120. Chou CC, Fine JS, Pugliese-Sivo C, Gonsiorek W, Davies L, Deno G, Petro M, Schwarz M, Zavodny PJ and Hipkin RW. (2002) Pharmacological characterization of the chemokine receptor, hCCR1 in a stable transfectant and differentiated HL-60 cells: antagonism of hCCR1 activation by MIP-1beta. Br. J. Pharmacol. 137: 663-75 [PMID:12381680]

121. Christensen JE, Nansen A, Moos T, Lu B, Gerard C, Christensen JP and Thomsen AR. (2004) Efficient Tcell surveillance of the CNS requires expression of the CXC chemokine receptor 3. J. Neurosci. 24: 484958 [PMID:15152045]

122. Chuntharapai A, Lee J, Hébert CA and Kim KJ. (1994) Monoclonal antibodies detect different distribution patterns of IL-8 receptor A and IL-8 receptor B on human peripheral blood leukocytes. J. Immunol. 153: 5682-8 [PMID:7527448]

123. Chvatchko Y, Hoogewerf AJ, Meyer A, Alouani S, Juillard P, Buser R, Conquet F, Proudfoot AE, Wells TN and Power CA. (2000) A key role for CC chemokine receptor 4 in lipopolysaccharide-induced endotoxic shock. J. Exp. Med. 191: 1755-64 [PMID:10811868] 
124. Citro A, Cantarelli E, Maffi $P$, Nano R, Melzi R, Mercalli A, Dugnani E, Sordi V, Magistretti $P$ and Daffonchio $L$ et al.. (2012) CXCR1/2 inhibition enhances pancreatic islet survival after transplantation.J. Clin. Invest. 122: 3647-51 [PMID:22996693]

125. Clark VJ and Dean M. (2004) Haplotype structure and linkage disequilibrium in chemokine and chemokine receptor genes. Hum. Genomics 1: 255-73 [PMID:15588486]

126. Clark VJ and Dean M. (2004) Characterisation of SNP haplotype structure in chemokine and chemokine receptor genes using CEPH pedigrees and statistical estimation. Hum. Genomics 1: 195-207 [PMID:15588479]

127. Clemetson KJ, Clemetson JM, Proudfoot AE, Power CA, Baggiolini M and Wells TN. (2000) Functional expression of CCR1, CCR3, CCR4, and CXCR4 chemokine receptors on human platelets. Blood 96: 404654 [PMID:11110672]

128. Coelho A, Matos A, Catarino R, Pinto D, Pereira D, Lopes C and Medeiros R. (2005) Protective role of the polymorphism CCR2-64I in the progression from squamous intraepithelial lesions to invasive cervical carcinoma. Gynecol. Oncol. 96: 760-4 [PMID:15721423]

129. Cohen-Hillel E, Yron I, Meshel T, Soria G, Attal H and Ben-Baruch A. (2006) CXCL8-induced FAK phosphorylation via CXCR1 and CXCR2: cytoskeleton- and integrin-related mechanisms converge with FAK regulatory pathways in a receptor-specific manner. Cytokine 33: 1-16 [PMID:16406804]

130. Colvin RA, Campanella GS, Sun J and Luster AD. (2004) Intracellular domains of CXCR3 that mediate CXCL9, CXCL10, and CXCL11 function. J. Biol. Chem. 279: 30219-27 [PMID:15150261]

131. Combadiere C, Ahuja SK and Murphy PM. (1995) Cloning, chromosomal localization, and RNA expression of a human beta chemokine receptor-like gene. DNA Cell Biol 14: 673-680 [PMID:7646814]

132. Combadiere C, Ahuja SK and Murphy PM. (1995) Cloning and functional expression of a human eosinophil CC chemokine receptor. J. Biol. Chem. 270: 16491-4 [PMID:7622448]

133. Combadiere C, Ahuja SK, Tiffany HL and Murphy PM. (1996) Cloning and functional expression of CC CKR5, a human monocyte CC chemokine receptor selective for MIP-1(alpha), MIP-1(beta), and RANTES. J. Leukoc. Biol. 60: 147-52 [PMID:8699119]

134. Combadiere C, Ahuja SK, Van Damme J, Tiffany HL, Gao JL and Murphy PM. (1995) Monocyte chemoattractant protein-3 is a functional ligand for $\mathrm{CC}$ chemokine receptors 1 and $2 \mathrm{~B}$. J Biol Chem 270: 29671-29675 [PMID:8530354]

135. Combadiere C, Gao J, Tiffany HL and Murphy PM. (1998) Gene cloning, RNA distribution, and functional expression of mCX3CR1, a mouse chemotactic receptor for the CX3C chemokine fractalkine. Biochem. Biophys. Res. Commun. 253: 728-32 [PMID:9918795]

136. Combadiere C, Salzwedel K, Smith ED, Tiffany HL, Berger EA and Murphy PM. (1998) Identification of CX3CR1. A chemotactic receptor for the human CX3C chemokine fractalkine and a fusion coreceptor for HIV-1. J. Biol. Chem. 273: 23799-23804 [PMID:9726990]

137. Combadière C, Potteaux S, Gao JL, Esposito B, Casanova S, Lee EJ, Debré P, Tedgui A, Murphy PM and Mallat Z. (2003) Decreased atherosclerotic lesion formation in CX3CR1/apolipoprotein E double knockout mice. Circulation 107: 1009-16 [PMID:12600915]

138. Corcione A, Tortolina G, Bonecchi R, Battilana N, Taborelli G, Malavasi F, Sozzani S, Ottonello L, Dallegri F and Pistoia V. (2002) Chemotaxis of human tonsil B lymphocytes to CC chemokine receptor (CCR) 1 , CCR2 and CCR4 ligands is restricted to non-germinal center cells. Int Immuno/ 14: 883-892 [PMID:12147625]

139. Coulin F, Power CA, Alouani S, Peitsch MC, Schroeder JM, Moshizuki M, Clark-Lewis I and Wells TN. (1997) Characterisation of macrophage inflammatory protein-5/human CC cytokine-2, a member of the macrophage-inflammatory-protein family of chemokines. Eur. J. Biochem. 248: 507-15 [PMID:9346309]

140. Crozat K, Guiton R, Contreras V, Feuillet V, Dutertre CA, Ventre E, Vu Manh TP, Baranek T, Storset AK and Marvel $\mathrm{J}$ et al.. (2010) The XC chemokine receptor 1 is a conserved selective marker of mammalian cells homologous to mouse CD8alpha+ dendritic cells. J. Exp. Med. 207: 1283-92 [PMID:20479118]

141. Crump MP, Gong JH, Loetscher P, Rajarathnam K, Amara A, Arenzana-Seisdedos F, Virelizier JL, Baggiolini M, Sykes BD and Clark-Lewis I. (1997) Solution structure and basis for functional activity of stromal cell-derived factor-1; dissociation of CXCR4 activation from binding and inhibition of HIV-1. EMBO J. 16: 6996-7007 [PMID:9384579]

142. Cumming JG. Slideset: CCR2 antagonists for the treatment of neuropathic pain. The discovery and development of AZD2423.

143. Cumming JG, Tucker H, Oldfield J, Fielding C, Highton A, Faull A, Wild M, Brown D, Wells S and Shaw J. (2012) Balancing hERG affinity and absorption in the discovery of AZD5672, an orally active CCR5 antagonist for the treatment of rheumatoid arthritis. Bioorg. Med. Chem. Lett. 22: 1655-9 [PMID:22266038]

144. Cyster JG. (1999) Chemokines and cell migration in secondary lymphoid organs. Science 286: 2098-102 
[PMID:10617422]

145. CytoDyn. PRO 140

146. Dairaghi DJ, Fan RA, McMaster BE, Hanley MR and Schall TJ. (1999) HHV8-encoded VMIP-I selectively engages chemokine receptor CCR8. Agonist and antagonist profiles of viral chemokines. J. Biol. Chem. 274: 21569-74 [PMID:10419462]

147. Damon I, Murphy PM and Moss B. (1998) Broad spectrum chemokine antagonistic activity of a human poxvirus chemokine homolog. Proc. Natl. Acad. Sci. U.S.A. 95: 6403-7 [PMID:9600978]

148. Damås JK, Boullier A, Waehre T, Smith C, Sandberg WJ, Green S, Aukrust P and Quehenberger O. (2005) Expression of fractalkine (CX3CL1) and its receptor, CX3CR1, is elevated in coronary artery disease and is reduced during statin therapy. Arterioscler. Thromb. Vasc. Biol. 25: 2567-72 [PMID:16224053]

149. Daoudi M, Lavergne E, Garin A, Tarantino N, Debré P, Pincet F, Combadière C and Deterre P. (2004) Enhanced adhesive capacities of the naturally occurring lle249-Met280 variant of the chemokine receptor CX3CR1. J. Biol. Chem. 279: 19649-57 [PMID:14990582]

150. Dasse OA, Evans JL, Zhai H-X, Zou D, Kintigh JT, Chan F, Hamilton K, Hill E, Eckman JB and Higgins PJ et al.. (2007) Novel, Acidic CCR2 Receptor Antagonists: Lead Optimization Letters in Drug Design \& Discovery 4: 263-271

151. Daugherty BL, Siciliano SJ, DeMartino JA, Malkowitz L, Sirotina A and Springer MS. (1996) Cloning, expression, and characterization of the human eosinophil eotaxin receptor. J. Exp. Med. 183: 2349-54 [PMID:8642344]

152. Davalos-Misslitz AC, Rieckenberg J, Willenzon S, Worbs T, Kremmer E, Bernhardt G and Förster R. (2007) Generalized multi-organ autoimmunity in CCR7-deficient mice. Eur. J. Immunol. 37: 613-22 [PMID:17304629]

153. Davalos-Misslitz AC, Worbs T, Willenzon S, Bernhardt G and Förster R. (2007) Impaired responsiveness to T-cell receptor stimulation and defective negative selection of thymocytes in CCR7-deficient mice. Blood 110: 4351-9 [PMID:17785582]

154. Debes GF, Arnold CN, Young AJ, Krautwald S, Lipp M, Hay JB and Butcher EC. (2005) Chemokine receptor CCR7 required for T lymphocyte exit from peripheral tissues. Nat. Immunol. 6: 889-94 [PMID:16116468]

155. Deichmann M, Kronenwett $R$ and Haas R. (1997) Expression of the human immunodeficiency virus type-1 coreceptors CXCR-4 (fusin, LESTR) and CKR-5 in CD34+ hematopoietic progenitor cells. Blood 89: 35228 [PMID:9160656]

156. Del Rio L, Bennouna S, Salinas J and Denkers EY. (2001) CXCR2 deficiency confers impaired neutrophil recruitment and increased susceptibility during Toxoplasma gondii infection. J. Immunol. 167: 6503-9 [PMID:11714818]

157. Delézay O, Koch N, Yahi N, Hammache D, Tourres C, Tamalet C and Fantini J. (1997) Co-expression of CXCR4/fusin and galactosylceramide in the human intestinal epithelial cell line HT-29. AIDS 11: 1311-8 [PMID:9302439]

158. Deng HK, Unutmaz D, KewalRamani VN and Littman DR. (1997) Expression cloning of new receptors used by simian and human immunodeficiency viruses. Nature 388: 296-300 [PMID:9230441]

159. Devalaraja RM, Nanney LB, Du J, Qian Q, Yu Y, Devalaraja MN and Richmond A. (2000) Delayed wound healing in CXCR2 knockout mice. J. Invest. Dermatol. 115: 234-44 [PMID:10951241]

160. Devitt E, Lawless MW, Sadlier D, A Browne J, Walsh C and Crowe J. (2010) Early viral and peripheral blood mononuclear cell responses to pegylated interferon and ribavirin treatment: the first $24 \mathrm{~h}$. Eur $\mathrm{J}$ Gastroenterol Hepatol 22: 1211-20 [PMID:20631625]

161. Di Salvo J, Koch GE, Johnson KE, Blake AD, Daugherty BL, DeMartino JA, Sirotina-Meisher A, Liu Y, Springer MS and Cascieri MA et al.. (2000) The CXCR4 agonist ligand stromal derived factor-1 maintains high affinity for receptors in both Galpha(i)-coupled and uncoupled states. Eur. J. Pharmacol. 409: 143-54 [PMID:11104827]

162. Diana $J$ and Lehuen A. (2014) Macrophages and $\beta$-cells are responsible for CXCR2-mediated neutrophil infiltration of the pancreas during autoimmune diabetes. EMBO Mol Med 6: 1090-104 [PMID:24968718]

163. Dobner T, Wolf I, Emrich T and Lipp M. (1992) Differentiation-specific expression of a novel G proteincoupled receptor from Burkitt's lymphoma. Eur. J. Immunol. 22: 2795-9 [PMID:1425907]

164. Doroshenko T, Chaly Y, Savitskiy V, Maslakova O, Portyanko A, Gorudko I and Voitenok NN. (2002) Phagocytosing neutrophils down-regulate the expression of chemokine receptors CXCR1 and CXCR2. Blood 100: 2668-71 [PMID:12239185]

165. Drury LJ, Ziarek JJ, Gravel S, Veldkamp CT, Takekoshi T, Hwang ST, Heveker N, Volkman BF and Dwinell MB. (2011) Monomeric and dimeric CXCL12 inhibit metastasis through distinct CXCR4 
interactions and signaling pathways. Proc. Natl. Acad. Sci. U.S.A. 108: 17655-60 [PMID:21990345]

166. Duan Z, Chen X, Liang Z, Zeng Y, Zhu F, Long L, McCrae MA, Zhuang H, Shen T and Lu F. (2014) Genetic polymorphisms of CXCR5 and CXCL13 are associated with non-responsiveness to the hepatitis $B$ vaccine. Vaccine 32: 5316-22 [PMID:25077417]

167. Duggal P, An P, Beaty TH, Strathdee SA, Farzadegan H, Markham RB, Johnson L, O'Brien SJ, Vlahov D and Winkler CA. (2003) Genetic influence of CXCR6 chemokine receptor alleles on PCP-mediated AIDS progression among African Americans. Genes Immun. 4: 245-50 [PMID:12761559]

168. Dunstan CA, Salafranca MN, Adhikari S, Xia Y, Feng L and Harrison JK. (1996) Identification of two rat genes orthologous to the human interleukin-8 receptors. J Biol Chem 271: 32770-32776 [PMID:8955112]

169. Dwyer MP, Yu Y, Chao J, Aki C, Chao J, Biju P, Girijavallabhan V, Rindgen D, Bond R and Mayer-Ezel R et al.. (2006) Discovery of 2-hydroxy-N,N-dimethyl-3-\{2-[[(R)-1-(5- methylfuran-2-yl)propyl]amino]-3,4dioxocyclobut-1-enylamino\}benzamide (SCH 527123): a potent, orally bioavailable CXCR2/CXCR1 receptor antagonist. J. Med. Chem. 49: 7603-6 [PMID:17181143]

170. Eikawa S, Ohue Y, Kitaoka K, Aji T, Uenaka A, Oka M and Nakayama E. (2010) Enrichment of Foxp3+ CD4 regulatory T cells in migrated T cells to IL-6- and IL-8-expressing tumors through predominant induction of CXCR1 by IL-6. J. Immunol. 185: 6734-40 [PMID:21048114]

171. Enjuanes A, Benavente Y, Bosch F, Martín-Guerrero I, Colomer D, Pérez-Alvarez S, Reina O, Ardanaz MT, Jares P and García-Orad A et al.. (2008) Genetic variants in apoptosis and immunoregulation-related genes are associated with risk of chronic lymphocytic leukemia. Cancer Res. 68: 10178-86 [PMID:19074885]

172. Ernst MC, Issa M, Goralski KB and Sinal CJ. (2010) Chemerin exacerbates glucose intolerance in mouse models of obesity and diabetes. Endocrinology 151: 1998-2007 [PMID:20228173]

173. Fan P, Kyaw H, Su K, Zeng Z, Augustus M, Carter KC and Li Y. (1998) Cloning and characterization of a novel human chemokine receptor. Biochem. Biophys. Res. Commun. 243: 264-8 [PMID:9473515]

174. Farkas L, Hahn MC, Schmoczer M, Jentsch N, Krätzel K, Pfeifer M and Schulz C. (2005) Expression of CXC chemokine receptors 1 and 2 in human bronchial epithelial cells. Chest 128: 3724-34 [PMID:16304340]

175. Faure S, Meyer L, Costagliola D, Vaneensberghe C, Genin E, Autran B, Delfraissy JF, McDermott DH, Murphy PM and Debré P et al.. (2000) Rapid progression to AIDS in HIV+ individuals with a structural variant of the chemokine receptor CX3CR1. Science 287: 2274-7 [PMID:10731151]

176. Feng L, Chen S, Garcia GE, Xia Y, Siani MA, Botti P, Wilson CB, Harrison JK and Bacon KB. (1999) Prevention of crescentic glomerulonephritis by immunoneutralization of the fractalkine receptor CX3CR1 rapid communication. Kidney Int. 56: 612-20 [PMID:10432400]

177. Feng Y, Broder CC, Kennedy PE and Berger EA. (1996) HIV-1 entry cofactor: functional cDNA cloning of a seven-transmembrane, G protein-coupled receptor. Science 272: 872-7 [PMID:8629022]

178. Feniger-Barish R, Ran M, Zaslaver A and Ben-Baruch A. (1999) Differential modes of regulation of cxc chemokine-induced internalization and recycling of human CXCR1 and CXCR2. Cytokine 11: 996-1009 [PMID:10623425]

179. Feniger-Barish R, Yron I, Meshel T, Matityahu E and Ben-Baruch A. (2003) IL-8-induced migratory responses through CXCR1 and CXCR2: association with phosphorylation and cellular redistribution of focal adhesion kinase. Biochemistry 42: 2874-2886 [PMID:12627953]

180. Fife BT, Huffnagle GB, Kuziel WA and Karpus WJ. (2000) CC chemokine receptor 2 is critical for induction of experimental autoimmune encephalomyelitis. J. Exp. Med. 192: 899-905 [PMID:10993920]

181. Finke D, Acha-Orbea H, Mattis A, Lipp M and Kraehenbuhl J. (2002) CD4+CD3- cells induce Peyer's patch development: role of alpha4beta1 integrin activation by CXCR5. Immunity 17: 363-73 [PMID:12354388]

182. Flynn G, Maru S, Loughlin J, Romero IA and Male D. (2003) Regulation of chemokine receptor expression in human microglia and astrocytes. J. Neuroimmunol. 136: 84-93 [PMID:12620646]

183. Foley M, Pow A, Griffiths K, Cobb S and Viduka K. (2016) Cxcr4 binding molecules Patent number: WO2016109872.

184. Forssmann U, Uguccioni M, Loetscher P, Dahinden CA, Langen H, Thelen M and Baggiolini M. (1997) Eotaxin-2, a novel CC chemokine that is selective for the chemokine receptor CCR3, and acts like eotaxin on human eosinophil and basophil leukocytes. J. Exp. Med. 185: 2171-6 [PMID:9182688]

185. Fox JC, Nakayama T, Tyler RC, Sander TL, Yoshie O and Volkman BF. (2015) Structural and agonist properties of XCL2, the other member of the C-chemokine subfamily. Cytokine 71: 302-11 [PMID:25497737]

186. Frade JM, Llorente M, Mellado M, Alcamí J, Gutiérrez-Ramos JC, Zaballos A, Real G and Martínez-A C. (1997) The amino-terminal domain of the CCR2 chemokine receptor acts as coreceptor for HIV-1 infection. J. Clin. Invest. 100: 497-502 [PMID:9239395] 
187. Francis JN, Jacobson MR, Lloyd CM, Sabroe I, Durham SR and Till SJ. (2004) CXCR1+CD4+ T cells in human allergic disease. J. Immunol. 172: 268-73 [PMID:14688334]

188. Freeman CM, Chiu BC, Stolberg VR, Hu J, Zeibecoglou K, Lukacs NW, Lira SA, Kunkel SL and Chensue SW. (2005) CCR8 is expressed by antigen-elicited, IL-10-producing CD4+CD25+ T cells, which regulate Th2-mediated granuloma formation in mice. J. Immunol. 174: 1962-70 [PMID:15699124]

189. Frendéus B, Godaly G, Hang L, Karpman D, Lundstedt AC and Svanborg C. (2000) Interleukin 8 receptor deficiency confers susceptibility to acute experimental pyelonephritis and may have a human counterpart. J. Exp. Med. 192: 881-90 [PMID:10993918]

190. Fricker SP, Anastassov V, Cox J, Darkes MC, Grujic O, Idzan SR, Labrecque J, Lau G, Mosi RM and Nelson KL et al.. (2006) Characterization of the molecular pharmacology of AMD3100: a specific antagonist of the G-protein coupled chemokine receptor, CXCR4. Biochem. Pharmacol. 72: 588-96 [PMID:16815309]

191. Fu W, Zhang Y, Zhang J and Chen WF. (2005) Cloning and characterization of mouse homolog of the CXC chemokine receptor CXCR1. Cytokine 31: 9-17 [PMID:15967374]

192. Fujisawa T, Kato Y, Nagase H, Atsuta J, Terada A, Iguchi K, Kamiya H, Morita Y, Kitaura M and Kawasaki $\mathrm{H}$ et al.. (2000) Chemokines induce eosinophil degranulation through CCR-3.J. Allergy Clin. Immunol. 106: 507-13 [PMID:10984371]

193. Fukunaga K, Asano K, Mao XQ, Gao PS, Roberts MH, Oguma T, Shiomi T, Kanazawa M, Adra CN and Shirakawa T et al.. (2001) Genetic polymorphisms of CC chemokine receptor 3 in Japanese and British asthmatics. Eur. Respir. J. 17: 59-63 [PMID:11307756]

194. Förster R, Davalos-Misslitz AC and Rot A. (2008) CCR7 and its ligands: balancing immunity and tolerance. Nat. Rev. Immunol. 8: 362-71 [PMID:18379575]

195. Förster R, Mattis AE, Kremmer E, Wolf E, Brem G and Lipp M. (1996) A putative chemokine receptor, BLR1, directs $B$ cell migration to defined lymphoid organs and specific anatomic compartments of the spleen. Cell 87: 1037-47 [PMID:8978608]

196. Förster R, Schubel A, Breitfeld D, Kremmer E, Renner-Müller I, Wolf E and Lipp M. (1999) CCR7 coordinates the primary immune response by establishing functional microenvironments in secondary lymphoid organs. Cell 99: 23-33 [PMID:10520991]

197. Gade-Andavolu R, Comings DE, MacMurray J, Rostamkhani M, Cheng LS, Tourtellotte WW and Cone LA. (2004) Association of CCR5 delta32 deletion with early death in multiple sclerosis. Genet. Med. 6: 126-31 [PMID:15354329]

198. Galimberti D, Fenoglio C, Lovati C, Gatti A, Guidi I, Venturelli E, Cutter GR, Mariani C, Forloni G and Pettenati $C$ et al.. (2004) CCR2-64I polymorphism and CCR5Delta32 deletion in patients with Alzheimer's disease. J. Neurol. Sci. 225: 79-83 [PMID:15465089]

199. Galligan CL, Matsuyama W, Matsukawa A, Mizuta H, Hodge DR, Howard OM and Yoshimura T. (2004) Up-regulated expression and activation of the orphan chemokine receptor, CCRL2, in rheumatoid arthritis. Arthritis Rheum. 50: 1806-14 [PMID:15188357]

200. Gao JL and Murphy PM. (1995) Cloning and differential tissue-specific expression of three mouse beta chemokine receptor-like genes, including the gene for a functional macrophage inflammatory protein-1 alpha receptor. J Biol Chem 270: 17494-17501 [PMID:7542241]

201. Gao JL, Wynn TA, Chang Y, Lee EJ, Broxmeyer HE, Cooper S, Tiffany HL, Westphal H, Kwon-Chung J and Murphy PM. (1997) Impaired host defense, hematopoiesis, granulomatous inflammation and type 1type 2 cytokine balance in mice lacking CC chemokine receptor 1. J. Exp. Med. 185: 1959-68 [PMID:9166425]

202. Gao W, Topham PS, King JA, Smiley ST, Csizmadia V, Lu B, Gerard CJ and Hancock WW. (2000) Targeting of the chemokine receptor CCR1 suppresses development of acute and chronic cardiac allograft rejection. J. Clin. Invest. 105: 35-44 [PMID:10619859]

203. García-Zepeda EA, Licona-Limón I, Jiménez-Sólomon MF and Soldevila G. (2007) Janus kinase 3deficient T lymphocytes have an intrinsic defect in CCR7-mediated homing to peripheral lymphoid organs. Immunology 122: 247-60 [PMID:17521370]

204. Garin A, Tarantino N, Faure S, Daoudi M, Lécureuil C, Bourdais A, Debré P, Deterre P and Combadiere C. (2003) Two novel fully functional isoforms of CX3CR1 are potent HIV coreceptors. J. Immunol. 171: 530512 [PMID:14607932]

205. Gattorno M, Prigione I, Morandi F, Gregorio A, Chiesa S, Ferlito F, Favre A, Uccelli A, Gambini C and Martini A et al.. (2005) Phenotypic and functional characterisation of CCR7+ and CCR7- CD4+ memory T cells homing to the joints in juvenile idiopathic arthritis. Arthritis Res. Ther. 7: R256-67 [PMID:15743472]

206. Geissmann F, Jung S and Littman DR. (2003) Blood monocytes consist of two principal subsets with distinct migratory properties. Immunity 19: 71-82 [PMID:12871640] 
207. Gerber BO, Zanni MP, Uguccioni M, Loetscher M, Mackay CR, Pichler WJ, Yawalkar N, Baggiolini M and Moser B. (1997) Functional expression of the eotaxin receptor CCR3 in T lymphocytes co-localizing with eosinophils. Curr. Biol. 7: 836-43 [PMID:9480044]

208. Gerrits H, van Ingen Schenau DS, Bakker NE, van Disseldorp AJ, Strik A, Hermens LS, Koenen TB, Krajnc-Franken MA and Gossen JA. (2008) Early postnatal lethality and cardiovascular defects in CXCR7deficient mice. Genesis 46: 235-45 [PMID:18442043]

209. Ghasemzadeh M, Kaplan ZS, Alwis I, Schoenwaelder SM, Ashworth KJ, Westein E, Hosseini E, Salem $\mathrm{HH}$, Slattery R and McColl SR et al.. (2013) The CXCR1/2 ligand NAP-2 promotes directed intravascular leukocyte migration through platelet thrombi. Blood 121: 4555-66 [PMID:23550035]

210. Ghilardi G, Biondi ML, Turri O, Guagnellini E and Scorza R. (2004) Internal carotid artery occlusive disease and polymorphisms of fractalkine receptor CX3CR1: a genetic risk factor. Stroke 35: 1276-9 [PMID:15118174]

211. Ghobrial IM, Bone ND, Stenson MJ, Novak A, Hedin KE, Kay NE and Ansell SM. (2004) Expression of the chemokine receptors CXCR4 and CCR7 and disease progression in B-cell chronic lymphocytic leukemia/ small lymphocytic lymphoma. Mayo Clin. Proc. 79: 318-25 [PMID:15008605]

212. Giagulli C, Caccuri F, Cignarella F, Lougaris V, Martorelli D, Bugatti A, Rusnati M, Dolcetti R, Vitali M and Plebani A et al.. (2014) A CXCR1 haplotype hampers HIV-1 matrix protein p17 biological activity.AIDS 28: 2355-64 [PMID:25121556]

213. Giagulli C, Magiera AK, Bugatti A, Caccuri F, Marsico S, Rusnati M, Vermi W, Fiorentini S and Caruso A. (2012) HIV-1 matrix protein $p 17$ binds to the IL-8 receptor CXCR1 and shows IL-8-like chemokine activity on monocytes through Rho/ROCK activation. Blood 119: 2274-83 [PMID:22262769]

214. Gladue RP, Tylaska LA, Brissette WH, Lira PD, Kath JC, Poss CS, Brown MF, Paradis TJ, Conklyn MJ and Ogborne KT et al.. (2003) CP-481,715, a potent and selective CCR1 antagonist with potential therapeutic implications for inflammatory diseases. J. Biol. Chem. 278: 40473-80 [PMID:12909630]

215. Glass WG, Lim JK, Cholera R, Pletnev AG, Gao JL and Murphy PM. (2005) Chemokine receptor CCR5 promotes leukocyte trafficking to the brain and survival in West Nile virus infection. J. Exp. Med. 202: 108798 [PMID:16230476]

216. Glass WG, Liu MT, Kuziel WA and Lane TE. (2001) Reduced macrophage infiltration and demyelination in mice lacking the chemokine receptor CCR5 following infection with a neurotropic coronavirus. Virology 288: 8-17 [PMID:11543653]

217. Glass WG, McDermott DH, Lim JK, Lekhong S, Yu SF, Frank WA, Pape J, Cheshier RC and Murphy PM. (2006) CCR5 deficiency increases risk of symptomatic West Nile virus infection. J. Exp. Med. 203: 35-40 [PMID:16418398]

218. Godaly G, Hang L, Frendéus B and Svanborg C. (2000) Transepithelial neutrophil migration is CXCR1 dependent in vitro and is defective in IL-8 receptor knockout mice. J. Immunol. 165: 5287-94 [PMID:11046063]

219. Gong X, Gong W, Kuhns DB, Ben-Baruch A, Howard OM and Wang JM. (1997) Monocyte chemotactic protein-2 (MCP-2) uses CCR1 and CCR2B as its functional receptors. J. Biol. Chem. 272: 11682-5 [PMID:9115216]

220. Gonçalves AS and Appelberg R. (2002) The involvement of the chemokine receptor CXCR2 in neutrophil recruitment in LPS-induced inflammation and in Mycobacterium avium infection. Scand. J. Immunol. 55: 585-91 [PMID:12028561]

221. Gosling J, Dairaghi DJ, Wang Y, Hanley M, Talbot D, Miao Z and Schall TJ. (2000) Cutting edge: identification of a novel chemokine receptor that binds dendritic cell- and T cell-active chemokines including ELC, SLC, and TECK. J Immunol 164: 2851-2856 [PMID:10706668]

222. Gouwy M, Struyf S, Catusse J, Proost P and Van Damme J. (2004) Synergy between proinflammatory ligands of $G$ protein-coupled receptors in neutrophil activation and migration. J. Leukoc. Biol. 76: 185-94 [PMID:15075362]

223. Goya I, Gutiérrez J, Varona R, Kremer L, Zaballos A and Márquez G. (1998) Identification of CCR8 as the specific receptor for the human beta-chemokine I-309: cloning and molecular characterization of murine CCR8 as the receptor for TCA-3. J. Immunol. 160: 1975-81 [PMID:9469461]

224. Gravel S, Malouf C, Boulais PE, Berchiche YA, Oishi S, Fujii N, Leduc R, Sinnett D and Heveker N. (2010) The peptidomimetic CXCR4 antagonist TC14012 recruits beta-arrestin to CXCR7: roles of receptor domains. J. Biol. Chem. 285: 37939-43 [PMID:20956518]

225. Greaves DR, Wang W, Dairaghi DJ, Dieu MC, Saint-Vis B, Franz-Bacon K, Rossi D, Caux C, McClanahan T and Gordon S et al.. (1997) CCR6, a CC chemokine receptor that interacts with macrophage inflammatory protein 3alpha and is highly expressed in human dendritic cells. J. Exp. Med. 186: 837-44 [PMID:9294138] 
226. Guo J, Van Eck M, de Waard V, Maeda N, Benson GM, Groot PH and Van Berkel TJ. (2005) The presence of leukocyte CC-chemokine receptor 2 in CCR2 knockout mice promotes atherogenesis. Biochim. Biophys. Acta 1740: 453-9 [PMID:15949714]

227. Gupta SK and Pillarisetti K. (1999) Cutting edge: CXCR4-Lo: molecular cloning and functional expression of a novel human CXCR4 splice variant. J. Immunol. 163: 2368-72 [PMID:10452968]

228. Gustavsson M, Wang L, van Gils N, Stephens BS, Zhang P, Schall TJ, Yang S, Abagyan R, Chance MR and Kufareva I et al.. (2017) Structural basis of ligand interaction with atypical chemokine receptor 3Nat Commun 8: 14135 [PMID:28098154]

229. Habasque C, Aubry F, Jégou B and Samson M. (2002) Study of the HIV-1 receptors CD4, CXCR4, CCR5 and CCR3 in the human and rat testis. Mol. Hum. Reprod. 8: 419-25 [PMID:11994538]

230. Hale SJ, Hale AB, Zhang Y, Sweeney D, Fisher N, van der Garde M, Grabowska R, Pepperell E, Channon $\mathrm{K}$ and Martin-Rendon E et al.. (2015) CXCR2 modulates bone marrow vascular repair and haematopoietic recovery post-transplant. Br. J. Haematol. 169: 552-64 [PMID:25757087]

231. Hall DA, Beresford IJ, Browning C and Giles H. (1999) Signalling by CXC-chemokine receptors 1 and 2 expressed in $\mathrm{CHO}$ cells: a comparison of calcium mobilization, inhibition of adenylyl cyclase and stimulation of GTPgammaS binding induced by IL-8 and GROalpha. Br. J. Pharmacol. 126: 810-8 [PMID:10188995]

232. Hall LR, Diaconu E, Patel R and Pearlman E. (2001) CXC chemokine receptor 2 but not C-C chemokine receptor 1 expression is essential for neutrophil recruitment to the cornea in helminth-mediated keratitis (river blindness). J. Immunol. 166: 4035-41 [PMID:11238651]

233. Hang L, Frendéus B, Godaly G and Svanborg C. (2000) Interleukin-8 receptor knockout mice have subepithelial neutrophil entrapment and renal scarring following acute pyelonephritis. J Infect Dis 182: 1738-1748 [PMID:11069247]

234. Hansen A, Lipsky PE and Dörner T. (2007) B cells in Sjögren's syndrome: indications for disturbed selection and differentiation in ectopic lymphoid tissue. Arthritis Res. Ther. 9: 218 [PMID:17697366]

235. Hardison JL, Wrightsman RA, Carpenter PM, Kuziel WA, Lane TE and Manning JE. (2006) The CC chemokine receptor 5 is important in control of parasite replication and acute cardiac inflammation following infection with Trypanosoma cruzi. Infect. Immun. 74: 135-43 [PMID:16368966]

236. Hardtke S, Ohl L and Förster R. (2005) Balanced expression of CXCR5 and CCR7 on follicular T helper cells determines their transient positioning to lymph node follicles and is essential for efficient B-cell help. Blood 106: 1924-31 [PMID:15899919]

237. Hartmann TN, Leick M, Ewers S, Diefenbacher A, Schraufstatter I, Honczarenko M and Burger M. (2008) Human $B$ cells express the orphan chemokine receptor CRAM-A/B in a maturation-stage-dependent and CCL5-modulated manner. Immunology 125: 252-62 [PMID:18397265]

238. Haskell CA, Horuk R, Liang M, Rosser M, Dunning L, Islam I, Kremer L, Gutiérrez J, Marquez G and Martinez-A C et al.. (2006) Identification and characterization of a potent, selective nonpeptide agonist of the CC chemokine receptor CCR8. Mol. Pharmacol. 69: 309-16 [PMID:16221874]

239. Hayes IM, Jordan NJ, Towers S, Smith G, Paterson JR, Earnshaw JJ, Roach AG, Westwick J and Williams RJ. (1998) Human vascular smooth muscle cells express receptors for CC chemokines. Arterioscler. Thromb. Vasc. Biol. 18: 397-403 [PMID:9514408]

240. Heesen M, Berman MA, Benson JD, Gerard C and Dorf ME. (1996) Cloning of the mouse fusin gene, homologue to a human HIV-1 co-factor. J. Immunol. 157: 5455-60 [PMID:8955194]

241. Heesen M, Berman MA, Höpken UE, Gerard NP and Dorf ME. (1997) Alternate splicing of mouse fusin/CXC chemokine receptor-4: stromal cell-derived factor-1alpha is a ligand for both CXC chemokine receptor-4 isoforms. J. Immunol. 158: 3561-4 [PMID:9103415]

242. Heiber M, Docherty JM, Shah G, Nguyen T, Cheng R, Heng HH, Marchese A, Tsui LC, Shi X and George $\mathrm{SR}$ et al.. (1995) Isolation of three novel human genes encoding $\mathrm{G}$ protein-coupled receptors.DNA Cell Biol. 14: 25-35 [PMID:7832990]

243. Heinemann A, Hartnell A, Stubbs VE, Murakami K, Soler D, LaRosa G, Askenase PW, Williams TJ and Sabroe I. (2000) Basophil responses to chemokines are regulated by both sequential and cooperative receptor signaling. J. Immunol. 165: 7224-33 [PMID:11120855]

244. Heise CE, Pahuja A, Hudson SC, Mistry MS, Putnam AL, Gross MM, Gottlieb PA, Wade WS, Kiankarimi $M$ and Schwarz D et al.. (2005) Pharmacological characterization of CXC chemokine receptor 3 ligands and a small molecule antagonist. J. Pharmacol. Exp. Ther.313: 1263-71 [PMID:15761110]

245. Held KS, Chen BP, Kuziel WA, Rollins BJ and Lane TE. (2004) Differential roles of CCL2 and CCR2 in host defense to coronavirus infection. Virology 329: 251-60 [PMID:15518805]

246. Herlea-Pana O, Yao L, Heuser-Baker J, Wang Q, Wang Q, Georgescu C, Zou MH and Barlic-Dicen J. (2015) Chemokine receptors CXCR2 and CX3CR1 differentially regulate functional responses of bone- 
marrow endothelial progenitors during atherosclerotic plaque regression. Cardiovasc. Res. 106: 324-37 [PMID:25765938]

247. Hernandez PA, Gorlin RJ, Lukens JN, Taniuchi S, Bohinjec J, Francois F, Klotman ME and Diaz GA. (2003) Mutations in the chemokine receptor gene CXCR4 are associated with WHIM syndrome, a combined immunodeficiency disease. Nat. Genet. 34: 70-4 [PMID:12692554]

248. Hesselgesser J, Liang M, Hoxie J, Greenberg M, Brass LF, Orsini MJ, Taub D and Horuk R. (1998) Identification and characterization of the CXCR4 chemokine receptor in human T cell lines: ligand binding, biological activity, and HIV-1 infectivity. J. Immunol. 160: 877-83 [PMID:9551924]

249. Hesselgesser J, Ng HP, Liang M, Zheng W, May K, Bauman JG, Monahan S, Islam I, Wei GP and Ghannam A et al.. (1998) Identification and characterization of small molecule functional antagonists of the CCR1 chemokine receptor. J. Biol. Chem. 273: 15687-92 [PMID:9624164]

250. Hesselgesser J, Taub D, Baskar P, Greenberg M, Hoxie J, Kolson DL and Horuk R. (1998) Neuronal apoptosis induced by HIV-1 gp120 and the chemokine SDF-1 alpha is mediated by the chemokine receptor CXCR4. Curr. Biol. 8: 595-8 [PMID:9601645]

251. Hizawa N, Yamaguchi E, Furuya K, Jinushi E, Ito A and Kawakami Y. (1999) The role of the C-C chemokine receptor 2 gene polymorphism V64I (CCR2-64I) in sarcoidosis in a Japanese population. Am. J. Respir. Crit. Care Med. 159: 2021-3 [PMID:10351956]

252. Hokeness KL, Kuziel WA, Biron CA and Salazar-Mather TP. (2005) Monocyte chemoattractant protein-1 and CCR2 interactions are required for IFN-alpha/beta-induced inflammatory responses and antiviral defense in liver. J. Immunol. 174: 1549-56 [PMID:15661915]

253. Holmes WE, Lee J, Kuang WJ, Rice GC and Wood WI. (1991) Structure and functional expression of a human interleukin-8 receptor. Science 253: 1278-80 [PMID:1840701]

254. Homey B, Alenius H, Müller A, Soto H, Bowman EP, Yuan W, McEvoy L, Lauerma Al, Assmann T and Bünemann E et al.. (2002) CCL27-CCR10 interactions regulate T cell-mediated skin inflammation.Nat. Med. 8: 157-65 [PMID:11821900]

255. Homey B, Dieu-Nosjean MC, Wiesenborn A, Massacrier C, Pin JJ, Oldham E, Catron D, Buchanan ME, Müller $A$ and deWaal Malefyt $R$ et al.. (2000) Up-regulation of macrophage inflammatory protein-3 alpha/CCL20 and CC chemokine receptor 6 in psoriasis. J. Immunol. 164: 6621-32 [PMID:10843722]

256. Homey B, Wang W, Soto H, Buchanan ME, Wiesenborn A, Catron D, Muller A, McClanahan TK, DieuNosjean MC, Orozco R, Ruzicka T, Lehmann P, Oldham E and Zlotnik A. (2000) Cutting edge: the orphan chemokine receptor $\mathrm{G}$ protein-coupled receptor-2 (GPR-2, CCR10) binds the skin-associated chemokine CCL27 (CTACK/ALP/ILC). J. Immunol. 164: 3465-3470 [PMID:10725697]

257. Honczarenko M, Le Y, Swierkowski M, Ghiran I, Glodek AM and Silberstein LE. (2006) Human bone marrow stromal cells express a distinct set of biologically functional chemokine receptors. Stem Cells 24: 1030-41 [PMID:16253981]

258. Horuk R, Martin AW, Wang Z, Schweitzer L, Gerassimides A, Guo H, Lu Z, Hesselgesser J, Perez HD and Kim J et al.. (1997) Expression of chemokine receptors by subsets of neurons in the central nervous system. J. Immunol. 158: 2882-90 [PMID:9058825]

259. Hosoe N, Miura S, Watanabe C, Tsuzuki Y, Hokari R, Oyama T, Fujiyama Y, Nagata H and Ishii H. (2004) Demonstration of functional role of TECK/CCL25 in T lymphocyte-endothelium interaction in inflamed and uninflamed intestinal mucosa. Am. J. Physiol. Gastrointest. Liver Physiol.286: G458-66 [PMID:14592943]

260. Hou Y, Wu Y, Farooq SM, Guan X, Wang S, Liu Y, Oblak JJ, Holcomb J, Jiang Y and Strieter RNet al.. (2015) A critical role of CXCR2 PDZ-mediated interactions in endothelial progenitor cell homing and angiogenesis. Stem Cell Res 14: 133-43 [PMID:25622052]

261. Hsieh CY, Chen CL, Lin YS, Yeh TM, Tsai TT, Hong MY and Lin CF. (2014) Macrophage migration inhibitory factor triggers chemotaxis of CD74+CXCR2+ NKT cells in chemically induced IFN-y-mediated skin inflammation. J. Immunol. 193: 3693-703 [PMID:25172501]

262. Huang H, Li F, Cairns CM, Gordon JR and Xiang J. (2001) Neutrophils and B cells express XCR1 receptor and chemotactically respond to lymphotactin. Biochem. Biophys. Res. Commun. 281: 378-82 [PMID:11181058]

263. Huber TB, Reinhardt HC, Exner M, Burger JA, Kerjaschki D, Saleem MA and Pavenstädt H. (2002) Expression of functional CCR and CXCR chemokine receptors in podocytes. J. Immunol. 168: 6244-52 [PMID:12055238]

264. Huffnagle GB, McNeil LK, McDonald RA, Murphy JW, Toews GB, Maeda N and Kuziel WA. (1999) Cutting edge: Role of $\mathrm{C}-\mathrm{C}$ chemokine receptor 5 in organ-specific and innate immunity to Cryptococcus neoformans. J. Immunol. 163: 4642-6 [PMID:10528159]

265. Hughes RO, Devraj RV, Rogier DJ, Trujillo JI, Turner SR and Huang W. (2012) 3aminocyclopentanecarboxamides as chemokine receptor agonists. Patent number: US8293903B2. 
266. Humbles AA, Lu B, Friend DS, Okinaga S, Lora J, Al-Garawi A, Martin TR, Gerard NP and Gerard C. (2002) The murine CCR3 receptor regulates both the role of eosinophils and mast cells in allergen-induced airway inflammation and hyperresponsiveness. Proc Natl Acad Sci U S A99: 1479-1484 [PMID:11830666]

267. Humpert ML, Tzouros M, Thelen S, Bignon A, Levoye A, Arenzana-Seisdedos F, Balabanian K, Bachelerie $\mathrm{F}$, Langen $\mathrm{H}$ and Thelen M. (2012) Complementary methods provide evidence for the expression of CXCR7 on human B cells. Proteomics 12: 1938-48 [PMID:22623068]

268. Hunter ZR, Xu L, Yang G, Zhou Y, Liu X, Cao Y, Manning RJ, Tripsas C, Patterson CJ and Sheehy Pet al.. (2014) The genomic landscape of Waldenstrom macroglobulinemia is characterized by highly recurring MYD88 and WHIM-like CXCR4 mutations, and small somatic deletions associated with B-cell lymphomagenesis. Blood 123: 1637-46 [PMID:24366360]

269. Hutchings CJ, Koglin M, Olson WC and Marshall FH. (2017) Opportunities for therapeutic antibodies directed at G-protein-coupled receptors. Nat Rev Drug Discov 16: 787-810 [PMID:28706220]

270. Hyde CL, Macinnes A, Sanders FA, Thompson JF, Mazzarella RA, Faergeman O, van Wijk DF, Wood L, Lira M and Paciga SA. (2010) Genetic association of the CCR5 region with lipid levels in at-risk cardiovascular patients. Circ Cardiovasc Genet 3: 162-8 [PMID:20130232]

271. Höpken UE, Achtman AH, Krüger K and Lipp M. (2004) Distinct and overlapping roles of CXCR5 and CCR7 in B-1 cell homing and early immunity against bacterial pathogens. J. Leukoc. Biol. 76: 709-18 [PMID:15197239]

272. Iellem A, Mariani M, Lang R, Recalde H, Panina-Bordignon P, Sinigaglia F and D'Ambrosio D. (2001) Unique chemotactic response profile and specific expression of chemokine receptors CCR4 and CCR8 by CD4(+)CD25(+) regulatory T cells. J. Exp. Med. 194: 847-53 [PMID:11560999]

273. likura M, Miyamasu M, Yamaguchi M, Kawasaki H, Matsushima K, Kitaura M, Morita Y, Yoshie O, Yamamoto K and Hirai K. (2001) Chemokine receptors in human basophils: inducible expression of functional CXCR4. J Leukoc Biol 70: 113-120 [PMID:11435493]

274. Imai T, Chantry D, Raport CJ, Wood CL, Nishimura M, Godiska R, Yoshie O and Gray PW. (1998) Macrophage-derived chemokine is a functional ligand for the CC chemokine receptor 4. J. Biol. Chem. 273: 1764-8 [PMID:9430724]

275. Imai T, Hieshima K, Haskell C, Baba M, Nagira M, Nishimura M, Kakizaki M, Takagi S, Nomiyama H and Schall TJ et al.. (1997) Identification and molecular characterization of fractalkine receptor CX3CR1, which mediates both leukocyte migration and adhesion. Cell 91: 521-30 [PMID:9390561]

276. Imamura S, Ichikawa T, Nishikawa Y, Kanzaki N, Takashima K, Niwa S, lizawa Y, Baba M and Sugihara Y. (2006) Discovery of a piperidine-4-carboxamide CCR5 antagonist (TAK-220) with highly potent AntiHIV-1 activity. J. Med. Chem. 49: 2784-93 [PMID:16640339]

277. Inngjerdingen M, Damaj B and Maghazachi AA. (2001) Expression and regulation of chemokine receptors in human natural killer cells. Blood 97: 367-75 [PMID:11154210]

278. Ishida K, Iwahashi M, Nakamori M, Nakamura M, Yokoyama S, lida T, Naka T, Nakamura Y and Yamaue H. (2009) High CCR7 mRNA expression of cancer cells is associated with lymph node involvement in patients with esophageal squamous cell carcinoma. Int. J. Oncol. 34: 915-22 [PMID:19287948]

279. Ishida T and Ueda R. (2006) CCR4 as a novel molecular target for immunotherapy of cancer.Cancer Sci. 97: 1139-46 [PMID:16952304]

280. Izikson L, Klein RS, Charo IF, Weiner HL and Luster AD. (2000) Resistance to experimental autoimmune encephalomyelitis in mice lacking the CC chemokine receptor (CCR)2. J. Exp. Med. 192: 1075-80 [PMID:11015448]

281. Jackson JJ, Ketcham JM, Younai A, Abraham B, Biannic B, Beck HP, Bui MHT, Chian D, Cutler G and Diokno $R$ et al.. (2019) Discovery of a Potent and Selective CCR4 Antagonist That Inhibits Treg Trafficking into the Tumor Microenvironment. J. Med. Chem. 62: 6190-6213 [PMID:31259550]

282. Jarmin DI, Rits M, Bota D, Gerard NP, Graham GJ, Clark-Lewis I and Gerard C. (2000) Cutting edge: Identification of the orphan receptor $\mathrm{G}$ protein-coupled receptor 2 as CCR10, a specific receptor for the chemokine ESkine. J. Immunol. 164: 3460-3464 [PMID:10725696]

283. Jarnagin K, Grunberger D, Mulkins M, Wong B, Hemmerich S, Paavola C, Bloom A, Bhakta S, Diehl F and Freedman $R$ et al.. (1999) Identification of surface residues of the monocyte chemotactic protein 1 that affect signaling through the receptor CCR2. Biochemistry 38: 16167-77 [PMID:10587439]

284. Javor J, Bucova M, Cervenova O, Kralinsky K, Sadova E, Suchankova M and Liptakova A. (2012) Genetic variations of interleukin-8, CXCR1 and CXCR2 genes and risk of acute pyelonephritis in children. Int. J. Immunogenet. 39: 338-45 [PMID:22325052]

285. Jenh $\mathrm{CH}$, Cox MA, Kaminski H, Zhang M, Byrnes H, Fine J, Lundell D, Chou CC, Narula SK and Zavodny PJ. (1999) Cutting edge: species specificity of the CC chemokine 6Ckine signaling through the CXC chemokine receptor CXCR3: human 6Ckine is not a ligand for the human or mouse CXCR3 receptors. J. 
Immunol. 162: 3765-9 [PMID:10201891]

286. Jiang Y, Salafranca MN, Adhikari S, Xia Y, Feng L, Sonntag MK, deFiebre CM, Pennell NA, Streit WJ and Harrison JK. (1998) Chemokine receptor expression in cultured glia and rat experimental allergic encephalomyelitis. J. Neuroimmunol. 86: 1-12 [PMID:9655467]

287. Jiménez-Sainz MC, Fast B, Mayor Jr F and Aragay AM. (2003) Signaling pathways for monocyte chemoattractant protein 1-mediated extracellular signal-regulated kinase activation. Mol. Pharmacol. 64: 773-82 [PMID:12920215]

288. Jinno A, Shimizu N, Soda Y, Haraguchi Y, Kitamura T and Hoshino H. (1998) Identification of the chemokine receptor TER1/CCR8 expressed in brain-derived cells and T cells as a new coreceptor for HIV1 infection. Biochem. Biophys. Res. Commun. 243: 497-502 [PMID:9480837]

289. Jinquan T, Jing C, Jacobi HH, Reimert CM, Millner A, Quan S, Hansen JB, Dissing S, Malling HJ and Skov PS et al.. (2000) CXCR3 expression and activation of eosinophils: role of IFN-gamma-inducible protein-10 and monokine induced by IFN-gamma. J. Immunol. 165: 1548-56 [PMID:10903763]

290. Johnston RA, Mizgerd JP and Shore SA. (2005) CXCR2 is essential for maximal neutrophil recruitment and methacholine responsiveness after ozone exposure. Am. J. Physiol. Lung Cell Mol. Physiol.288: L617 [PMID:15361358]

291. Jones SA, Dewald B, Clark-Lewis I and Baggiolini M. (1997) Chemokine antagonists that discriminate between interleukin-8 receptors. Selective blockers of CXCR2. J. Biol. Chem. 272: 16166-9 [PMID:9195914]

292. Jones SA, Wolf M, Qin S, Mackay CR and Baggiolini M. (1996) Different functions for the interleukin 8 receptors (IL-8R) of human neutrophil leukocytes: NADPH oxidase and phospholipase D are activated through IL-8R1 but not IL-8R2. Proc. Natl. Acad. Sci. U.S.A. 93: 6682-6 [PMID:8692878]

293. Jordan NJ, Kolios G, Abbot SE, Sinai MA, Thompson DA, Petraki K and Westwick J. (1999) Expression of functional CXCR4 chemokine receptors on human colonic epithelial cells. J. Clin. Invest. 104: 1061-9 [PMID:10525044]

294. Junt T, Fink K, Förster R, Senn B, Lipp M, Muramatsu M, Zinkernagel RM, Ludewig B and Hengartner H. (2005) CXCR5-dependent seeding of follicular niches by $B$ and Th cells augments antiviral B cell responses. J. Immunol. 175: 7109-16 [PMID:16301613]

295. Jurcevic S, Humfrey C, Uddin M, Warrington S, Larsson B and Keen C. (2015) The effect of a selective CXCR2 antagonist (AZD5069) on human blood neutrophil count and innate immune functions. Br J Clin Pharmacol 80: 1324-36 [PMID:26182832]

296. Juremalm M, Olsson N and Nilsson G. (2002) Selective CCL5/RANTES-induced mast cell migration through interactions with chemokine receptors CCR1 and CCR4. Biochem. Biophys. Res. Commun. 297: 480-5 [PMID:12270118]

297. Jülg B and Goebel FD. (2005) CCR5 antagonists: a new tool in fighting HIV.J HIV Ther 10: 68-71 [PMID:16519245]

298. Jülg B and Goebel FD. (2005) What's New in HIV/AIDS? Chemokine receptor antagonists: a new era of HIV therapy? Infection 33: 408-410 [PMID:16258879]

299. Kaiser E, Förster R, Wolf I, Ebensperger C, KuehI WM and Lipp M. (1993) The G protein-coupled receptor BLR1 is involved in murine B cell differentiation and is also expressed in neuronal tissues. Eur. J. Immunol. 23: 2532-9 [PMID:8405054]

300. Kalatskaya I, Berchiche YA, Gravel S, Limberg BJ, Rosenbaum JS and Heveker N. (2009) AMD3100 is a CXCR7 ligand with allosteric agonist properties. Mol. Pharmacol. 75: 1240-7 [PMID:19255243]

301. Kalindjian SB, Kadnur SV, Hewson CA, Venkateshappa C, Juluri S, Kristam R, Kulkarni B, Mohammed Z, Saxena R and Viswanadhan VN et al.. (2016) A New Series of Orally Bioavailable Chemokine Receptor 9 (CCR9) Antagonists; Possible Agents for the Treatment of Inflammatory Bowel Disease. J. Med. Chem. 59: 3098-111 [PMID:26987013]

302. Kampen GT, Stafford S, Adachi T, Jinquan T, Quan S, Grant JA, Skov PS, Poulsen LK and Alam R. (2000) Eotaxin induces degranulation and chemotaxis of eosinophils through the activation of ERK2 and p38 mitogen-activated protein kinases. Blood 95: 1911-7 [PMID:10706854]

303. Kanbe K, Shimizu N, Soda Y, Takagishi K and Hoshino H. (1999) A CXC chemokine receptor, CXCR5/BLR1, is a novel and specific coreceptor for human immunodeficiency virus type 2. Virology 265: 264-73 [PMID:10600598]

304. Kapas S and Clark AJ. (1995) Identification of an orphan receptor gene as a type 1 calcitonin gene-related peptide receptor. Biochem. Biophys. Res. Commun. 217: 832-8 [PMID:8554605]

305. Kaser A, Ludwiczek O, Holzmann S, Moschen AR, Weiss G, Enrich B, Graziadei I, Dunzendorfer S, Wiedermann CJ and Mürzl E et al.. (2004) Increased expression of CCL20 in human inflammatory bowel disease. J. Clin. Immunol. 24: 74-85 [PMID:14997037] 
306. Kato H, Tsuchiya N, Izumi S, Miyamasu M, Nakajima T, Kawasaki H, Hirai K and Tokunaga K. (1999) New variations of human CC-chemokine receptors CCR3 and CCR4. Genes Immun. 1: 97-104 [PMID:11196669]

307. Katoh H, Wang D, Daikoku T, Sun H, Dey SK and Dubois RN. (2013) CXCR2-expressing myeloid-derived suppressor cells are essential to promote colitis-associated tumorigenesis. Cancer Cell 24: 631-44 [PMID:24229710]

308. Kelsen SG, Aksoy MO, Yang Y, Shahabuddin S, Litvin J, Safadi F and Rogers TJ. (2004) The chemokine receptor CXCR3 and its splice variant are expressed in human airway epithelial cells. Am J Physiol Lung Cell Mol Physiol 287: L584-L591 [PMID:15155273]

309. Kemp DM, Pidich A, Larijani M, Jonas R, Lash E, Sato T, Terai M, De Pizzol M, Allegretti M and Igoucheva O et al.. (2017) Ladarixin, a dual CXCR1/2 inhibitor, attenuates experimental melanomas harboring different molecular defects by affecting malignant cells and tumor microenvironment. Oncotarget 8: 1442814442 [PMID:28129639]

310. Kielian T, Barry B and Hickey WF. (2001) CXC chemokine receptor-2 ligands are required for neutrophilmediated host defense in experimental brain abscesses. J. Immunol. 166: 4634-43 [PMID:11254722]

311. Kim CH, Kunkel EJ, Boisvert J, Johnston B, Campbell JJ, Genovese MC, Greenberg HB and Butcher EC. (2001) Bonzo/CXCR6 expression defines type 1-polarized T-cell subsets with extralymphoid tissue homing potential. J. Clin. Invest. 107: 595-601 [PMID:11238560]

312. Kim IS, Jang SW, Sung HJ, Lee JS and Ko J. (2005) Differential CCR1-mediated chemotaxis signaling induced by human CC chemokine HCC-4/CCL16 in HOS cells. FEBS Lett. 579: 6044-8 [PMID:16226254]

313. Kim JW, Ferris RL and Whiteside TL. (2005) Chemokine C receptor 7 expression and protection of circulating CD8+ T lymphocytes from apoptosis. Clin. Cancer Res. 11: 7901-10 [PMID:16278415]

314. Kim SJ, Shin JY, Lee KD, Bae YK, Sung KW, Nam SJ and Chun KH. (2012) MicroRNA let-7a suppresses breast cancer cell migration and invasion through downregulation of $\mathrm{C}-\mathrm{C}$ chemokine receptor type 7. Breast Cancer Res. 14: R14 [PMID:22251626]

315. Kindon N, Andrews G, Baxter A, Cheshire D, Hemsley P, Johnson T, Liu YZ, McGinnity D, McHale M and Mete A et al.. (2017) Discovery of AZD-2098 and AZD-1678, Two Potent and Bioavailable CCR4 Receptor Antagonists. ACS Med Chem Lett 8: 981-986 [PMID:28947948]

316. Kiss H, Darai E, Kiss C, Kost-Alimova M, Klein G, Dumanski JP and Imreh S. (2002) Comparative human/murine sequence analysis of the common eliminated region 1 from human 3p21.3. Mamm. Genome 13: 646-55 [PMID:12461651]

317. Kitagawa K, Wada T, Furuichi K, Hashimoto H, Ishiwata Y, Asano M, Takeya M, Kuziel WA, Matsushima $\mathrm{K}$ and Mukaida $\mathrm{N}$ et al.. (2004) Blockade of CCR2 ameliorates progressive fibrosis in kidney. Am. J. Pathol. 165: 237-46 [PMID:15215179]

318. Kitaura M, Suzuki N, Imai T, Takagi S, Suzuki R, Nakajima T, Hirai K, Nomiyama H and Yoshie O. (1999) Molecular cloning of a novel human CC chemokine (Eotaxin-3) that is a functional ligand of CC chemokine receptor 3. J. Biol. Chem. 274: 27975-80 [PMID:10488147]

319. Kitchen SG and Zack JA. (1997) CXCR4 expression during lymphopoiesis: implications for human immunodeficiency virus type 1 infection of the thymus. J. Virol.71: 6928-34 [PMID:9261420]

320. Kivisäkk P, Trebst C, Lee JC, Tucky BH, Rudick RA, Campbell JJ and Ransohoff RM. (2003) Expression of CCR2, CCR5, and CXCR3 by CD4+ T cells is stable during a 2-year longitudinal study but varies widely between individuals. J. Neurovirol. 9: 291-9 [PMID:12775413]

321. Kledal TN, Rosenkilde MM, Coulin F, Simmons G, Johnsen AH, Alouani S, Power CA, Lüttichau HR, Gerstoft J and Clapham PR et al.. (1997) A broad-spectrum chemokine antagonist encoded by Kaposi's sarcoma-associated herpesvirus. Science 277: 1656-9 [PMID:9287217]

322. Klein KR, Karpinich NO, Espenschied ST, Willcockson HH, Dunworth WP, Hoopes SL, Kushner EJ, Bautch VL and Caron KM. (2014) Decoy receptor CXCR7 modulates adrenomedullin-mediated cardiac and lymphatic vascular development. Dev. Cell 30: 528-40 [PMID:25203207]

323. Kleinewietfeld M, Puentes F, Borsellino G, Battistini L, Rötzschke O and Falk K. (2005) CCR6 expression defines regulatory effector/memory-like cells within the CD25(+)CD4+ T-cell subset. Blood 105: 2877-86 [PMID:15613550]

324. Ko J, Kim IS, Jang SW, Lee YH, Shin SY, Min DS and Na DS. (2002) Leukotactin-1/CCL15-induced chemotaxis signaling through CCR1 in HOS cells. FEBS Lett. 515: 159-64 [PMID:11943214]

325. Kohout TA, Nicholas SL, Perry SJ, Reinhart G, Junger S and Struthers RS. (2004) Differential desensitization, receptor phosphorylation, beta-arrestin recruitment, and ERK1/2 activation by the two endogenous ligands for the CC chemokine receptor 7. J Biol Chem 279: 23214-23222 [PMID:15054093]

326. Kormann MS, Hector A, Marcos V, Mays LE, Kappler M, Illig T, Klopp N, Zeilinger S, Carevic M and Rieber $\mathrm{N}$ et al.. (2012) CXCR1 and CXCR2 haplotypes synergistically modulate cystic fibrosis lung 
disease. Eur. Respir. J. 39: 1385-90 [PMID:22088968]

327. Kouba M, Vanetti M, Wang X, Schäfer M and Höllt V. (1993) Cloning of a novel putative G-protein-coupled receptor (NLR) which is expressed in neuronal and lymphatic tissue. FEBS Lett. 321: 173-8 [PMID:8386678]

328. Kouroumalis A, Nibbs RJ, Aptel H, Wright KL, Kolios G and Ward SG. (2005) The chemokines CXCL9, CXCL10, and CXCL11 differentially stimulate $G$ alpha i-independent signaling and actin responses in human intestinal myofibroblasts. J. Immunol. 175: 5403-11 [PMID:16210647]

329. Kowalska MA, Ratajczak J, Hoxie J, Brass LF, Gewirtz A, Poncz M and Ratajczak MZ. (1999) Megakaryocyte precursors, megakaryocytes and platelets express the HIV co-receptor CXCR4 on their surface: determination of response to stromal-derived factor- 1 by megakaryocytes and platelets. Br. J. Haematol. 104: 220-9 [PMID:10050701]

330. Krohn SC, Bonvin P and Proudfoot AE. (2013) CCL18 exhibits a regulatory role through inhibition of receptor and glycosaminoglycan binding. PLoS ONE 8: e72321 [PMID:23951310]

331. Krueger A, Willenzon S, Lyszkiewicz M, Kremmer E and Förster R. (2010) CC chemokine receptor 7 and 9 double-deficient hematopoietic progenitors are severely impaired in seeding the adult thymus. Blood 115: 1906-12 [PMID:20040757]

332. Krug A, Towarowski A, Britsch S, Rothenfusser S, Hornung V, Bals R, Giese T, Engelmann H, Endres S and Krieg AM et al.. (2001) Toll-like receptor expression reveals CpG DNA as a unique microbial stimulus for plasmacytoid dendritic cells which synergizes with CD40 ligand to induce high amounts of IL-12. Eur. J. Immunol. 31: 3026-37 [PMID:11592079]

333. Krzysiek R, Lefevre EA, Bernard J, Foussat A, Galanaud P, Louache F and Richard Y. (2000) Regulation of CCR6 chemokine receptor expression and responsiveness to macrophage inflammatory protein3alpha/CCL20 in human B cells. Blood 96: 2338-45 [PMID:11001880]

334. Kuhne M, Brams P, Tanamachi DM, Korman AJ and Cardarelli JM. (2013) Human monoclonal antibodies that bind CXCR4 Patent number: US8450464 B2.

335. Kumar S, Kwei GY, Poon GK, lliff SA, Wang Y, Chen Q, Franklin RB, Didolkar V, Wang RW and Yamazaki $M$ et al.. (2003) Pharmacokinetics and interactions of a novel antagonist of chemokine receptor 5 (CCR5) with ritonavir in rats and monkeys: role of CYP3A and P-glycoprotein. J. Pharmacol. Exp. Ther. 304: 116171 [PMID:12604693]

336. Kurihara T and Bravo R. (1996) Cloning and functional expression of mCCR2, a murine receptor for the CC chemokines JE and FIC. J. Biol. Chem. 271: 11603-7 [PMID:8662823]

337. Kurihara T, Warr G, Loy J and Bravo R. (1997) Defects in macrophage recruitment and host defense in mice lacking the CCR2 chemokine receptor. J. Exp. Med. 186: 1757-62 [PMID:9362535]

338. Kurobe H, Liu C, Ueno T, Saito F, Ohigashi I, Seach N, Arakaki R, Hayashi Y, Kitagawa T and Lipp Net al.. (2006) CCR7-dependent cortex-to-medulla migration of positively selected thymocytes is essential for establishing central tolerance. Immunity 24: 165-77 [PMID:16473829]

339. Kuziel WA, Morgan SJ, Dawson TC, Griffin S, Smithies O, Ley K and Maeda N. (1997) Severe reduction in leukocyte adhesion and monocyte extravasation in mice deficient in $\mathrm{CC}$ chemokine receptor 2. Proc. Natl. Acad. Sci. U.S.A. 94: 12053-8 [PMID:9342361]

340. Köhler A, De Filippo K, Hasenberg M, van den Brandt C, Nye E, Hosking MP, Lane TE, Männ L, Ransohoff RM and Hauser AE et al.. (2011) G-CSF-mediated thrombopoietin release triggers neutrophil motility and mobilization from bone marrow via induction of Cxcr2 ligands. Blood 117: 4349-57 [PMID:21224471]

341. Lagane B, Chow KY, Balabanian K, Levoye A, Harriague J, Planchenault T, Baleux F, Gunera-Saad N, Arenzana-Seisdedos F and Bachelerie F. (2008) CXCR4 dimerization and beta-arrestin-mediated signaling account for the enhanced chemotaxis to CXCL12 in WHIM syndrome. Blood 112: 34-44 [PMID:18436740]

342. Lalani AS and McFadden G. (1999) Evasion and exploitation of chemokines by viruses. Cytokine Growth Factor Rev. 10: 219-233 [PMID:10647778]

343. Lamkhioued B, Abdelilah SG, Hamid Q, Mansour N, Delespesse G and Renzi PM. (2003) The CCR3 receptor is involved in eosinophil differentiation and is up-regulated by Th2 cytokines in CD34+ progenitor cells. J. Immunol. 170: 537-47 [PMID:12496441]

344. Larochelle A, Krouse A, Metzger M, Orlic D, Donahue RE, Fricker S, Bridger G, Dunbar CE and Hematti P. (2006) AMD3100 mobilizes hematopoietic stem cells with long-term repopulating capacity in nonhuman primates. Blood 107: 3772-8 [PMID:16439684]

345. LaRosa GJ, Horvath C, Newman W, Jones T, O'Brien SH and O'Keefe T. (2004) Humanized anti-CCR2 antibodies and methods of use therefor. Patent number: US6696550 B2.

346. Lasagni L, Francalanci M, Annunziato F, Lazzeri E, Giannini S, Cosmi L, Sagrinati C, Mazzinghi B, 
Orlando C and Maggi E et al.. (2003) An alternatively spliced variant of CXCR3 mediates the inhibition of endothelial cell growth induced by IP-10, Mig, and I-TAC, and acts as functional receptor for platelet factor 4. J. Exp. Med. 197: 1537-49 [PMID:12782716]

347. Lavergne E, Labreuche J, Daoudi M, Debré $P$, Cambien F, Deterre $P$, Amarenco $P$, Combadière $C$ and GENIC Investigators. (2005) Adverse associations between CX3CR1 polymorphisms and risk of cardiovascular or cerebrovascular disease. Arterioscler. Thromb. Vasc. Biol. 25: 847-53 [PMID:15681302]

348. Lee B, Doranz BJ, Rana S, Yi Y, Mellado M, Frade JM, Martinez-A C, O'Brien SJ, Dean M and Collman $R G$ et al.. (1998) Influence of the CCR2-V64I polymorphism on human immunodeficiency virus type 1 coreceptor activity and on chemokine receptor function of CCR2b, CCR3, CCR5, and CXCR4. J. Virol. 72: 7450-8 [PMID:9696841]

349. Lee HT, Shiao YM, Wu TH, Chen WS, Hsu YH, Tsai SF and Tsai CY. (2010) Serum BLC/CXCL13 concentrations and renal expression of CXCL13/CXCR5 in patients with systemic lupus erythematosus and lupus nephritis. J. Rheumatol. 37: 45-52 [PMID:19955043]

350. Lee J, Horuk R, Rice GC, Bennett GL, Camerato T and Wood WI. (1992) Characterization of two high affinity human interleukin-8 receptors. J. Biol. Chem. 267: 16283-7 [PMID:1379593]

351. Legler DF, Loetscher M, Roos RS, Clark-Lewis I, Baggiolini M and Moser B. (1998) B cell-attracting chemokine 1, a human CXC chemokine expressed in lymphoid tissues, selectively attracts $B$ lymphocytes via BLR1/CXCR5. J. Exp. Med. 187: 655-60 [PMID:9463416]

352. Lei $Y$ and Takahama Y. (2012) XCL1 and XCR1 in the immune system.Microbes Infect. 14: 262-7 [PMID:22100876]

353. Leick M, Catusse J, Follo M, Nibbs RJ, Hartmann TN, Veelken H and Burger M. (2010) CCL19 is a specific ligand of the constitutively recycling atypical human chemokine receptor CRAM-B. Immunology 129: 53646 [PMID:20002784]

354. Lesnik P, Haskell CA and Charo IF. (2003) Decreased atherosclerosis in CX3CR1-/- mice reveals a role for fractalkine in atherogenesis. J. Clin. Invest. 111: 333-40 [PMID:12569158]

355. Levoye A, Balabanian K, Baleux F, Bachelerie F and Lagane B. (2009) CXCR7 heterodimerizes with CXCR4 and regulates CXCL12-mediated G protein signaling. Blood 113: 6085-93 [PMID:19380869]

356. Li A, Dubey S, Varney ML and Singh RK. (2002) Interleukin-8-induced proliferation, survival, and MMP production in CXCR1 and CXCR2 expressing human umbilical vein endothelial cells. Microvasc. Res. 64: 476-81 [PMID:12453441]

357. Li A, Varney ML, Valasek J, Godfrey M, Dave BJ and Singh RK. (2005) Autocrine role of interleukin-8 in induction of endothelial cell proliferation, survival, migration and MMP-2 production and angiogenesis. Angiogenesis 8: 63-71 [PMID:16132619]

358. Li L, Pennell AMK and Zhang P. (2008) 3-(imidazolyl)-pyrazolo[3,4-b]pyridines Patent number: WO2008147815A1.

359. Liang M, Mallari C, Rosser M, Ng HP, May K, Monahan S, Bauman JG, Islam I, Ghannam A and Buckman B et al.. (2000) Identification and characterization of a potent, selective, and orally active antagonist of the CC chemokine receptor-1. J. Biol. Chem. 275: 19000-8 [PMID:10748002]

360. Liao F, Alkhatib G, Peden KW, Sharma G, Berger EA and Farber JM. (1997) STRL33, A novel chemokine receptor-like protein, functions as a fusion cofactor for both macrophage-tropic and T cell line-tropic HIV-1. J. Exp. Med. 185: 2015-23 [PMID:9166430]

361. Liao F, Lee HH and Farber JM. (1997) Cloning of STRL22, a new human gene encoding a G-proteincoupled receptor related to chemokine receptors and located on chromosome 6q27. Genomics 40: 175-80 [PMID:9070937]

362. Liao F, Rabin RL, Smith CS, Sharma G, Nutman TB and Farber JM. (1999) CC-chemokine receptor 6 is expressed on diverse memory subsets of $T$ cells and determines responsiveness to macrophage inflammatory protein 3 alpha. J. Immunol. 162: 186-94 [PMID:9886385]

363. Lisignoli G, Toneguzzi S, Piacentini A, Cattini L, Lenti A, Tschon M, Cristino S, Grassi F and Facchini A. (2003) Human osteoblasts express functional CXC chemokine receptors 3 and 5: activation by their ligands, CXCL10 and CXCL13, significantly induces alkaline phosphatase and beta-Nacetylhexosaminidase release. J. Cell. Physiol. 194: 71-9 [PMID:12447991]

364. Lisignoli G, Toneguzzi S, Piacentini A, Cristino S, Cattini L, Grassi F and Facchini A. (2004) Recruitment and proliferation of T lymphocytes is supported by IFNgamma- and TNFalpha-activated human osteoblasts: Involvement of CD54 (ICAM-1) and CD106 (VCAM-1) adhesion molecules and CXCR3 chemokine receptor. J. Cell. Physiol. 198: 388-98 [PMID:14755544]

365. Liu FY, Safdar J, Li ZN, Fang QG, Zhang X, Xu ZF and Sun CF. (2014) CCR7 regulates cell migration and invasion through MAPKs in metastatic squamous cell carcinoma of head and neck. Int. J. Oncol. 45: 250210 [PMID:25270024] 
366. Liu JX, Cao X, Tang YC, Liu Y and Tang FR. (2007) CCR7, CCR8, CCR9 and CCR10 in the mouse hippocampal CA1 area and the dentate gyrus during and after pilocarpine-induced status epilepticus. $J$. Neurochem. 100: 1072-88 [PMID:17181556]

367. Liu Q, Chen T, Chen G, Shu X, Sun A, Ma P, Lu L and Cao X. (2007) Triptolide impairs dendritic cell migration by inhibiting CCR7 and COX-2 expression through PI3-K/Akt and NF-kappaB pathways. Mol. Immunol. 44: 2686-96 [PMID:17223196]

368. Liu X, Mao J, Han C, Peng S, Li C, Jin T, Fan C, Shan Z and Teng W. (2016) CXCR4 antagonist AMD3100 ameliorates thyroid damage in autoimmune thyroiditis in NOD.H-2h4 mice. Mol Med Rep 13: 3604-12 [PMID:26935473]

369. Loetscher M, Amara A, Oberlin E, Brass N, Legler D, Loetscher P, D'Apuzzo M, Meese E, Rousset D and Virelizier JL et al.. (1997) TYMSTR, a putative chemokine receptor selectively expressed in activated T cells, exhibits HIV-1 coreceptor function. Curr. Biol. 7: 652-60 [PMID:9285716]

370. Loetscher M, Geiser T, O'Reilly T, Zwahlen R, Baggiolini M and Moser B. (1994) Cloning of a human seven-transmembrane domain receptor, LESTR, that is highly expressed in leukocytes. J. Biol. Chem. 269: 232-7 [PMID:8276799]

371. Loetscher M, Loetscher P, Brass N, Meese E and Moser B. (1998) Lymphocyte-specific chemokine receptor CXCR3: regulation, chemokine binding and gene localization. Eur. J. Immunol. 28: 3696-705 [PMID:9842912]

372. Loetscher P, Gong JH, Dewald B, Baggiolini M and Clark-Lewis I. (1998) N-terminal peptides of stromal cell-derived factor-1 with CXC chemokine receptor 4 agonist and antagonist activities. J. Biol. Chem. 273: 22279-83 [PMID:9712844]

373. Lu M, Grove EA and Miller RJ. (2002) Abnormal development of the hippocampal dentate gyrus in mice lacking the CXCR4 chemokine receptor. Proc. Natl. Acad. Sci. U.S.A. 99: 7090-5 [PMID:11983855]

374. Luchtefeld M, Grothusen C, Gagalick A, Jagavelu K, Schuett H, Tietge UJ, Pabst O, Grote K, Drexler H and Förster $\mathrm{R}$ et al.. (2010) Chemokine receptor 7 knockout attenuates atherosclerotic plaque development. Circulation 122: 1621-8 [PMID:20921438]

375. Ludwig A, Ehlert JE, Flad HD and Brandt E. (2000) Identification of distinct surface-expressed and intracellular CXC-chemokine receptor 2 glycoforms in neutrophils: $\mathrm{N}$-glycosylation is essential for maintenance of receptor surface expression. J. Immunol. 165: 1044-52 [PMID:10878382]

376. Lukacs NW, Prosser DM, Wiekowski M, Lira SA and Cook DN. (2001) Requirement for the chemokine receptor CCR6 in allergic pulmonary inflammation. J. Exp. Med. 194: 551-5 [PMID:11514610]

377. López-Giral S, Quintana NE, Cabrerizo M, Alfonso-Pérez M, Sala-Valdés M, De Soria VG, FernándezRañada JM, Fernández-Ruiz E and Muñoz C. (2004) Chemokine receptors that mediate B cell homing to secondary lymphoid tissues are highly expressed in B cell chronic lymphocytic leukemia and non-Hodgkin lymphomas with widespread nodular dissemination. J. Leukoc. Biol. 76: 462-71 [PMID:15155773]

378. Lügering A, Floer M, Westphal S, Maaser C, Spahn TW, Schmidt MA, Domschke W, Williams IR and Kucharzik T. (2005) Absence of CCR6 inhibits CD4+ regulatory T-cell development and M-cell formation inside Peyer's patches. Am. J. Pathol. 166: 1647-54 [PMID:15920150]

379. Lüttichau HR. (2010) The cytomegalovirus UL146 gene product vCXCL1 targets both CXCR1 and CXCR2 as an agonist. J. Biol. Chem. 285: 9137-46 [PMID:20044480]

380. Lüttichau HR, Clark-Lewis I, Jensen PØ, Moser C, Gerstoft J and Schwartz TW. (2003) A highly selective CCR2 chemokine agonist encoded by human herpesvirus 6. J. Biol. Chem. 278: 10928-33 [PMID:12554737]

381. Lüttichau HR, Lewis IC, Gerstoft J and Schwartz TW. (2001) The herpesvirus 8-encoded chemokine vMIPII, but not the poxvirus-encoded chemokine MC148, inhibits the CCR10 receptor. Eur. J. Immunol. 31: 1217-20 [PMID:11298347]

382. Ma H, Gao L, Li S, Qin J, Chen L, Liu X, Xu P, Wang F, Xiao H and Zhou \&et al.. (2015) CCR7 enhances TGF- $\beta 1$-induced epithelial-mesenchymal transition and is associated with lymph node metastasis and poor overall survival in gastric cancer. Oncotarget 6: 24348-60 [PMID:26176983]

383. Ma M, Wei T, Boring L, Charo IF, Ransohoff RM and Jakeman LB. (2002) Monocyte recruitment and myelin removal are delayed following spinal cord injury in mice with CCR2 chemokine receptor deletion. $J$. Neurosci. Res. 68: 691-702 [PMID:12111830]

384. Ma W, Bryce PJ, Humbles AA, Laouini D, Yalcindag A, Alenius H, Friend DS, Oettgen HC, Gerard C and Geha RS. (2002) CCR3 is essential for skin eosinophilia and airway hyperresponsiveness in a murine model of allergic skin inflammation. J. Clin. Invest. 109: 621-8 [PMID:11877470]

385. Machado FS, Koyama NS, Carregaro V, Ferreira BR, Milanezi CM, Teixeira MM, Rossi MA and Silva JS. (2005) CCR5 plays a critical role in the development of myocarditis and host protection in mice infected with Trypanosoma cruzi. J. Infect. Dis. 191: 627-36 [PMID:15655788] 
386. Mack M, Cihak J, Simonis C, Luckow B, Proudfoot AE, Plachý J, Brühl H, Frink M, Anders HJ and Vielhauer $V$ et al.. (2001) Expression and characterization of the chemokine receptors CCR2 and CCR5 in mice. J. Immunol. 166: 4697-704 [PMID:11254730]

387. Maeda DY, Peck AM, Schuler AD, Quinn MT, Kirpotina LN, Wicomb WN, Fan GH and Zebala JA. (2014) Discovery of 2-[5-(4-Fluorophenylcarbamoyl)pyridin-2-ylsulfanylmethyl]phenylboronic Acid (SX-517): Noncompetitive Boronic Acid Antagonist of CXCR1 and CXCR2. J. Med. Chem. 57: 8378-97 [PMID:25254640]

388. Maeda K, Das D, Ogata-Aoki H, Nakata H, Miyakawa T, Tojo Y, Norman R, Takaoka Y, Ding J, Arnold GF, Arnold E and Mitsuya H. (2006) Structural and molecular interactions of CCR5 inhibitors with CCR5. J Biol Chem 281: 12688-12698 [PMID:16476734]

389. Maeda K, Yoshimura K, Shibayama S, Habashita H, Tada H, Sagawa K, Miyakawa T, Aoki M, Fukushima D and Mitsuya H. (2001) Novel low molecular weight spirodiketopiperazine derivatives potently inhibit R5 HIV-1 infection through their antagonistic effects on CCR5. J. Biol. Chem. 276: 35194-200 [PMID:11454872]

390. Mangano A, Kopka J, Batalla M, Bologna R and Sen L. (2000) Protective effect of CCR2-64I and not of CCR5-delta32 and SDF1-3'A in pediatric HIV-1 infection. J. Acquir. Immune Defic. Syndr. 23: 52-7 [PMID:10708056]

391. Marchese A, Docherty JM, Nguyen T, Heiber M, Cheng R, Heng HH, Tsui LC, Shi X, George SR and O'Dowd BF. (1994) Cloning of human genes encoding novel G protein-coupled receptors. Genomics 23: 609-18 [PMID:7851889]

392. Matheson MC, Ellis JA, Raven J, Walters EH and Abramson MJ. (2006) Association of IL8, CXCR2 and TNF-alpha polymorphisms and airway disease. J. Hum. Genet. 51: 196-203 [PMID:16429233]

393. Matloubian M, David A, Engel S, Ryan JE and Cyster JG. (2000) A transmembrane CXC chemokine is a ligand for HIV-coreceptor Bonzo. Nat. Immunol. 1: 298-304 [PMID:11017100]

394. McDermott DH, Fong AM, Yang Q, Sechler JM, Cupples LA, Merrell MN, Wilson PW, D'Agostino RB, O'Donnell CJ, Patel DD and Murphy PM. (2003) Chemokine receptor mutant CX3CR1-M280 has impaired adhesive function and correlates with protection from cardiovascular disease in humans. J Clin Invest 111: 1241-1250 [PMID:12697743]

395. McDermott DH, Gao JL, Liu Q, Siwicki M, Martens C, Jacobs P, Velez D, Yim E, Bryke CR and Hsu Net al.. (2015) Chromothriptic cure of WHIM syndrome. Cell 160: 686-99 [PMID:25662009]

396. McDermott DH, Halcox JP, Schenke WH, Waclawiw MA, Merrell MN, Epstein N, Quyyumi AA and Murphy PM. (2001) Association between polymorphism in the chemokine receptor CX3CR1 and coronary vascular endothelial dysfunction and atherosclerosis. Circ. Res. 89: 401-7 [PMID:11532900]

397. McDermott DH, Zimmerman PA, Guignard F, Kleeberger CA, Leitman SF and Murphy PM. (1998) CCR5 promoter polymorphism and HIV-1 disease progression. Multicenter AIDS Cohort Study (MACS). Lancet 352: 866-70 [PMID:9742978]

398. Meijer J, Zeelenberg IS, Sipos B and Roos E. (2006) The CXCR5 chemokine receptor is expressed by carcinoma cells and promotes growth of colon carcinoma in the liver. Cancer Res. 66: 9576-82 [PMID:17018614]

399. Mells GF, Floyd JA, Morley KI, Cordell HJ, Franklin CS, Shin SY, Heneghan MA, Neuberger JM, Donaldson PT and Day DB et al.. (2011) Genome-wide association study identifies 12 new susceptibility loci for primary biliary cirrhosis. Nat. Genet. 43: 329-32 [PMID:21399635]

400. Melo RCC, Longhini AL, Bigarella CL, Baratti MO, Traina F, Favaro P, de Melo Campos P and Saad ST. (2014) CXCR7 is highly expressed in acute lymphoblastic leukemia and potentiates CXCR4 response to CXCL12. PLOS ONE 9: e85926 [PMID:24497931]

401. Merfeld DM, Young LR, Tomko DL and Paige GD. (1991) Spatial orientation of VOR to combined vestibular stimuli in squirrel monkeys. Acta Otolaryngol Supp/ 481: 287-92 [PMID:1927397]

402. Merz D, Liu R, Johnson K and Terkeltaub R. (2003) IL-8/CXCL8 and growth-related oncogene alpha/CXCL1 induce chondrocyte hypertrophic differentiation. J. Immunol. 171: 4406-15 [PMID:14530367]

403. Meucci O, Fatatis A, Simen AA, Bushell TJ, Gray PW and Miller RJ. (1998) Chemokines regulate hippocampal neuronal signaling and gp120 neurotoxicity. Proc. Natl. Acad. Sci. U.S.A. 95: 14500-5 [PMID:9826729]

404. Michel G, Kemény L, Peter RU, Beetz A, Ried C, Arenberger P and Ruzicka T. (1992) Interleukin-8 receptor-mediated chemotaxis of normal human epidermal cells. FEBS Lett. 305: 241-3 [PMID:1299623]

405. Mihara K, Smit MJ, Krajnc-Franken M, Gossen J, Rooseboom M and Dokter W. (2005) Human CXCR2 (hCXCR2) takes over functionalities of its murine homolog in hCXCR2 knockin mice. Eur. J. Immunol. 35: 2573-82 [PMID:16094689]

406. Milatovic S, Nanney LB, Yu Y, White JR and Richmond A. (2003) Impaired healing of nitrogen mustard 
wounds in CXCR2 null mice. Wound Repair Regen 11: 213-9 [PMID:12753603]

407. Miller AL, Strieter RM, Gruber AD, Ho SB and Lukacs NW. (2003) CXCR2 regulates respiratory syncytial virus-induced airway hyperreactivity and mucus overproduction. J. Immunol. 170: 3348-56

[PMID:12626595]

408. Miller BE, Mistry S, Smart K, Connolly P, Carpenter DC, Cooray H, Bloomer JC, Tal-Singer R and Lazaar AL. (2015) The pharmacokinetics and pharmacodynamics of danirixin (GSK1325756) - a selective CXCR2 antagonist - in healthy adult subjects. BMC Pharmacol Toxicol 16: 18 [PMID:26092545]

409. Miller EJ, Jecs E, Truax VM, Katzman BM, Tahirovic YA, Wilson RJ, Kuo KM, Kim MB, Nguyen HH and Saindane MT et al.. (2018) Discovery of Tetrahydroisoquinoline-Containing CXCR4 Antagonists with Improved in Vitro ADMET Properties. J. Med. Chem. 61: 946-979 [PMID:29350534]

410. Mirzadegan T, Diehl F, Ebi B, Bhakta S, Polsky I, McCarley D, Mulkins M, Weatherhead GS, Lapierre JM and Dankwardt J et al.. (2000) Identification of the binding site for a novel class of CCR2b chemokine receptor antagonists: binding to a common chemokine receptor motif within the helical bundle. J. Biol. Chem. 275: 25562-71 [PMID:10770925]

411. Misrahi M, Teglas JP, N'Go N, Burgard M, Mayaux MJ, Rouzioux C, Delfraissy JF and Blanche S. (1998) CCR5 chemokine receptor variant in HIV-1 mother-to-child transmission and disease progression in children. French Pediatric HIV Infection Study Group. JAMA 279: 277-80 [PMID:9450710]

412. Misslitz A, Pabst O, Hintzen G, Ohl L, Kremmer E, Petrie HT and Förster R. (2004) Thymic T cell development and progenitor localization depend on CCR7. J. Exp. Med. 200: 481-91 [PMID:15302903]

413. Mo R, Chen J, Han Y, Bueno-Cannizares C, Misek DE, Lescure PA, Hanash S and Yung RL. (2003) T cell chemokine receptor expression in aging. J. Immunol. 170: 895-904 [PMID:12517955]

414. Moatti D, Faure S, Fumeron F, Amara Mel-W, Seknadji P, McDermott DH, Debré P, Aumont MC, Murphy PM and de Prost $D$ et al.. (2001) Polymorphism in the fractalkine receptor CX3CR1 as a genetic risk factor for coronary artery disease. Blood 97: 1925-8 [PMID:11264153]

415. Moepps B, Frodl R, Rodewald HR, Baggiolini M and Gierschik P. (1997) Two murine homologues of the human chemokine receptor CXCR4 mediating stromal cell-derived factor 1alpha activation of Gi2 are differentially expressed in vivo. Eur. J. Immunol. 27: 2102-12 [PMID:9295051]

416. Molyneaux KA, Zinszner H, Kunwar PS, Schaible K, Stebler J, Sunshine MJ, O'Brien W, Raz E, Littman D and Wylie $C$ et al.. (2003) The chemokine SDF1/CXCL12 and its receptor CXCR4 regulate mouse germ cell migration and survival. Development 130: 4279-86 [PMID:12900445]

417. Monnier J, Lewén S, O'Hara E, Huang K, Tu H, Butcher EC and Zabel BA. (2012) Expression, regulation, and function of atypical chemerin receptor CCRL2 on endothelial cells. J. Immunol. 189: 956-67 [PMID:22696441]

418. Mori S, Nakano H, Aritomi K, Wang CR, Gunn MD and Kakiuchi T. (2001) Mice lacking expression of the chemokines CCL21-ser and CCL19 (plt mice) demonstrate delayed but enhanced T cell immune responses. J. Exp. Med. 193: 207-18 [PMID:11148224]

419. Moriconi A, Cesta MC, Cervellera MN, Aramini A, Coniglio S, Colagioia S, Beccari AR, Bizzarri C, Cavicchia MR and Locati $M$ et al.. (2007) Design of noncompetitive interleukin-8 inhibitors acting on CXCR1 and CXCR2. J. Med. Chem. 50: 3984-4002 [PMID:17665889]

420. Morokata T, Suzuki K, Masunaga Y, Taguchi K, Morihira K, Sato I, Fujii M, Takizawa S, Torii $Y$ and Yamamoto $\mathrm{N}$ et al.. (2006) A novel, selective, and orally available antagonist for CC chemokine receptor 3. J. Pharmacol. Exp. Ther. 317: 244-50 [PMID:16339911]

421. Moschovakis GL, Bubke A, Dittrich-Breiholz O, Braun A, Prinz I, Kremmer E and Förster R. (2012) Deficient CCR7 signaling promotes TH2 polarization and B-cell activation in vivo. Eur. J. Immunol. 42: 4857 [PMID:21969271]

422. Mueller SG, White JR, Schraw WP, Lam V and Richmond A. (1997) Ligand-induced desensitization of the human CXC chemokine receptor-2 is modulated by multiple serine residues in the carboxyl-terminal domain of the receptor. J. Biol. Chem. 272: 8207-14 [PMID:9079638]

423. Mulherin SA, O'Brien TR, loannidis JP, Goedert JJ, Buchbinder SP, Coutinho RA, Jamieson BD, Meyer L, Michael NL and Pantaleo G et al.. (2003) Effects of CCR5-Delta32 and CCR2-64I alleles on HIV-1 disease progression: the protection varies with duration of infection. AIDS 17: 377-87 [PMID:12556692]

424. Murakami T, Cardones AR, Finkelstein SE, Restifo NP, Klaunberg BA, Nestle FO, Castillo SS, Dennis PA and Hwang ST. (2003) Immune evasion by murine melanoma mediated through CC chemokine receptor10. J. Exp. Med. 198: 1337-47 [PMID:14581607]

425. Murphy PM. (2002) International Union of Pharmacology. XXX. Update on chemokine receptor nomenclature. Pharmacol. Rev. 54: 227-9 [PMID:12037138]

426. Murphy PM, Baggiolini M, Charo IF, Hébert CA, Horuk R, Matsushima K, Miller LH, Oppenheim JJ and Power CA. (2000) International union of pharmacology. XXII. Nomenclature for chemokine receptors. 
Pharmacol. Rev. 52: 145-76 [PMID:10699158]

427. Murphy PM and Tiffany HL. (1991) Cloning of complementary DNA encoding a functional human interleukin-8 receptor. Science 253: 1280-3 [PMID:1891716]

428. Muruganandan S, Roman AA and Sinal CJ. (2010) Role of chemerin/CMKLR1 signaling in adipogenesis and osteoblastogenesis of bone marrow stem cells. J. Bone Miner. Res.25: 222-34 [PMID:19929432]

429. Müller $G$ and Lipp M. (2001) Signal transduction by the chemokine receptor CXCR5: structural requirements for $G$ protein activation analyzed by chimeric CXCR1/CXCR5 molecules. Biol. Chem. 382: 1387-97 [PMID:11688722]

430. Nakayama EE, Tanaka Y, Nagai Y, Iwamoto A and Shioda T. (2004) A CCR2-V64I polymorphism affects stability of CCR2A isoform. AIDS 18: 729-38 [PMID:15075507]

431. Nakayama T, Hieshima K, Izawa D, Tatsumi Y, Kanamaru A and Yoshie O. (2003) Cutting edge: profile of chemokine receptor expression on human plasma cells accounts for their efficient recruitment to target tissues. J. Immunol. 170: 1136-40 [PMID:12538668]

432. Nanki T and Lipsky PE. (2000) Lack of correlation between chemokine receptor and $T(h) 1 / T(h) 2$ cytokine expression by individual memory T cells. Int. Immunol. 12: 1659-67 [PMID:11099305]

433. Napier C, Sale H, Mosley M, Rickett G, Dorr P, Mansfield R and Holbrook M. (2005) Molecular cloning and radioligand binding characterization of the chemokine receptor CCR5 from rhesus macaque and human. Biochem. Pharmacol. 71: 163-72 [PMID:16298345]

434. Napolitano M, Zingoni A, Bernardini G, Spinetti G, Nista A, Storlazzi CT, Rocchi M and Santoni A. (1996) Molecular cloning of TER1, a chemokine receptor-like gene expressed by lymphoid tissues. J Immunol 157: 2759-2763 [PMID:8816377]

435. Naya A, Ishikawa M, Matsuda K, Ohwaki K, Saeki T, Noguchi K and Ohtake N. (2003) Structure-activity relationships of xanthene carboxamides, novel CCR1 receptor antagonists. Bioorg. Med. Chem. 11: 87584 [PMID:12614873]

436. Neighbour H, Boulet LP, Lemiere C, Sehmi R, Leigh R, Sousa AR, Martin J, Dallow N, Gilbert J and Allen A et al.. (2014) Safety and efficacy of an oral CCR3 antagonist in patients with asthma and eosinophilic bronchitis: a randomized, placebo-controlled clinical trial. Clin. Exp. Allergy 44: 508-16 [PMID:24286456]

437. Neptune ER and Bourne HR. (1997) Receptors induce chemotaxis by releasing the betagamma subunit of Gi, not by activating Gq or Gs. Proc. Natl. Acad. Sci. U.S.A. 94: 14489-94 [PMID:9405640]

438. Neptune ER, liri T and Bourne HR. (1999) Galphai is not required for chemotaxis mediated by Gi-coupled receptors. J. Biol. Chem. 274: 2824-8 [PMID:9915816]

439. Neusser MA, Kraus AK, Regele H, Cohen CD, Fehr T, Kerjaschki D, Wüthrich RP, Penfold ME, Schall T and Segerer S. (2010) The chemokine receptor CXCR7 is expressed on lymphatic endothelial cells during renal allograft rejection. Kidney Int. 77: 801-8 [PMID:20164826]

440. Ng-Cashin J, Kuhns JJ, Burkett SE, Powderly JD, Craven RR, van Deventer HW, Kirby SL and Serody JS. (2003) Host absence of CCR5 potentiates dendritic cell vaccination. J. Immunol. 170: 4201-8 [PMID:12682253]

441. Nibbs RJ and Graham GJ. (2013) Immune regulation by atypical chemokine receptors. Nat. Rev. Immunol. 13: 815-29 [PMID:24319779]

442. Nibbs RJ, Salcedo TW, Campbell JD, Yao XT, Li Y, Nardelli B, Olsen HS, Morris TS, Proudfoot AE and Patel VP et al.. (2000) C-C chemokine receptor 3 antagonism by the beta-chemokine macrophage inflammatory protein 4 , a property strongly enhanced by an amino-terminal alanine-methionine swap. $\mathrm{J}$. Immunol. 164: 1488-97 [PMID:10640766]

443. Nicholls DJ, Wiley K, Dainty I, MacIntosh F, Phillips C, Gaw A and Mårdh CK. (2015) Pharmacological characterization of AZD5069, a slowly reversible CXC chemokine receptor 2 antagonist. J. Pharmacol. Exp. Ther. 353: 340-50 [PMID:25736418]

444. Niessner A, Marculescu R, Haschemi A, Endler G, Zorn G, Weyand CM, Maurer G, Mannhalter C, Wojta J and Wagner $O$ et al.. (2005) Opposite effects of CX3CR1 receptor polymorphisms V249I and T280M on the development of acute coronary syndrome. A possible implication of fractalkine in inflammatory activation. Thromb. Haemost. 93: 949-54 [PMID:15886814]

445. Nilsson G, Mikovits JA, Metcalfe DD and Taub DD. (1999) Mast cell migratory response to interleukin-8 is mediated through interaction with chemokine receptor CXCR2/Interleukin-8RB. Blood 93: 2791-7 [PMID:10216072]

446. Nishiyori A, Minami M, Ohtani Y, Takami S, Yamamoto J, Kawaguchi N, Kume T, Akaike A and Satoh M. (1998) Localization of fractalkine and CX3CR1 mRNAs in rat brain: does fractalkine play a role in signaling from neuron to microglia? FEBS Lett. 429: 167-72 [PMID:9650583]

447. Noor S, Habashy AS, Nance JP, Clark RT, Nemati K, Carson MJ and Wilson EH. (2010) CCR7-dependent immunity during acute Toxoplasma gondii infection. Infect. Immun. 78: 2257-63 [PMID:20194594] 
448. O'Byrne PM, Metev H, Puu M, Richter K, Keen C, Uddin M, Larsson B, Cullberg M and Nair P. (2016) Efficacy and safety of a CXCR2 antagonist, AZD5069, in patients with uncontrolled persistent asthma: a randomised, double-blind, placebo-controlled trial. Lancet Respir Med 4: 797-806 [PMID:27574788]

449. Oberlin E, Amara A, Bachelerie F, Bessia C, Virelizier JL, Arenzana-Seisdedos F, Schwartz O, Heard JM, Clark-Lewis I and Legler DF et al.. (1996) The CXC chemokine SDF-1 is the ligand for LESTR/fusin and prevents infection by T-cell-line-adapted HIV-1. Nature 382: 833-5 [PMID:8752281]

450. Ochensberger B, Tassera L, Bifrare D, Rihs S and Dahinden CA. (1999) Regulation of cytokine expression and leukotriene formation in human basophils by growth factors, chemokines and chemotactic agonists. Eur. J. Immunol. 29: 11-22 [PMID:9933081]

451. Oh SB, Endoh T, Simen AA, Ren D and Miller RJ. (2002) Regulation of calcium currents by chemokines and their receptors. J. Neuroimmunol. 123: 66-75 [PMID:11880151]

452. Ohl L, Henning G, Krautwald S, Lipp M, Hardtke S, Bernhardt G, Pabst O and Förster R. (2003) Cooperating mechanisms of CXCR5 and CCR7 in development and organization of secondary lymphoid organs. J. Exp. Med. 197: 1199-204 [PMID:12732661]

453. Ohl L, Mohaupt M, Czeloth N, Hintzen G, Kiafard Z, Zwirner J, Blankenstein T, Henning G and Förster R. (2004) CCR7 governs skin dendritic cell migration under inflammatory and steady-state conditions. Immunity 21: 279-88 [PMID:15308107]

454. Okada T and Cyster JG. (2007) CC chemokine receptor 7 contributes to Gi-dependent T cell motility in the lymph node. J. Immunol. 178: 2973-8 [PMID:17312142]

455. Olszyna DP, Florquin S, Sewnath M, Branger J, Speelman P, van Deventer SJ, Strieter RM and van der Poll T. (2001) CXC chemokine receptor 2 contributes to host defense in murine urinary tract infection. $J$. Infect. Dis. 184: 301-7 [PMID:11443555]

456. Ometto L, Zanchetta M, Cabrelle A, Esposito G, Mainardi M, Chieco-Bianchi L and De Rossi A. (1999) Restriction of HIV type 1 infection in macrophages heterozygous for a deletion in the CC-chemokine receptor 5 gene. AIDS Res Hum Retroviruses 15: 1441-1452 [PMID:10555107]

457. Onai N, Kitabatake M, Zhang YY, Ishikawa H, Ishikawa S and Matsushima K. (2002) Pivotal role of CCL25 (TECK)-CCR9 in the formation of gut cryptopatches and consequent appearance of intestinal intraepithelial T lymphocytes. Int. Immunol. 14: 687-94 [PMID:12096027]

458. Ondeykal JG, Herath KB, Jayasuriya H, Polishook JD, Bills GF, Dombrowski AW, Mojena M, Koch G, DiSalvo J and DeMartino J et al.. (2005) Discovery of structurally diverse natural product antagonists of chemokine receptor CXCR3. Mol. Divers. 9: 123-9 [PMID:15789559]

459. Oostendorp J, Hylkema MN, Luinge M, Geerlings M, Meurs H, Timens W, Zaagsma J, Postma DS, Boddeke HW and Biber K. (2004) Localization and enhanced mRNA expression of the orphan chemokine receptor L-CCR in the lung in a murine model of ovalbumin-induced airway inflammation. J. Histochem. Cytochem. 52: 401-10 [PMID:14966207]

460. Opfermann P, Derhaschnig U, Felli A, Wenisch J, Santer D, Zuckermann A, Dworschak M, Jilma B and Steinlechner B. (2015) A pilot study on reparixin, a CXCR1/2 antagonist, to assess safety and efficacy in attenuating ischaemia-reperfusion injury and inflammation after on-pump coronary artery bypass graft surgery. Clin. Exp. Immunol. 180: 131-42 [PMID:25402332]

461. Ortlepp JR, Vesper K, Mevissen V, Schmitz F, Janssens U, Franke A, Hanrath P, Weber C, Zerres K and Hoffmann R. (2003) Chemokine receptor (CCR2) genotype is associated with myocardial infarction and heart failure in patients under 65 years of age. J. Mol. Med. 81: 363-7 [PMID:12719858]

462. Oswald C, Rappas M, Kean J, Doré AS, Errey JC, Bennett K, Deflorian F, Christopher JA, Jazayeri A and Mason JS et al.. (2016) Intracellular allosteric antagonism of the CCR9 receptor. Nature 540: 462-465 [PMID:27926729]

463. Otero K, Vecchi A, Hirsch E, Kearley J, Vermi W, Del Prete A, Gonzalvo-Feo S, Garlanda C, Azzolino O, Salogni L, Lloyd CM, Facchetti F, Mantovani A and Sozzani S. (2010) Nonredundant role of CCRL2 in lung dendritic cell trafficking. Blood 116: 2942-9 [PMID:20606167]

464. Ott TR, Lio FM, Olshefski D, Liu XJ, Ling N and Struthers RS. (2006) The N-terminal domain of CCL21 reconstitutes high affinity binding, $\mathrm{G}$ protein activation, and chemotactic activity, to the C-terminal domain of CCL19. Biochem. Biophys. Res. Commun. 348: 1089-93 [PMID:16904643]

465. Ottaviani C, Nasorri F, Bedini C, de Pità O, Girolomoni G and Cavani A. (2006) CD56brightCD16(-) NK cells accumulate in psoriatic skin in response to CXCL10 and CCL5 and exacerbate skin inflammation. Eur. J. Immunol. 36: 118-28 [PMID:16323244]

466. Pabst O, Ohl L, Wendland M, Wurbel MA, Kremmer E, Malissen B and Förster R. (2004) Chemokine receptor CCR9 contributes to the localization of plasma cells to the small intestine. J. Exp. Med.199: 4116 [PMID:14744993]

467. Palani A, Shapiro S, Clader JW, Greenlee WJ, Cox K, Strizki J, Endres M and Baroudy BM. (2001) 
Discovery of 4-[(Z)-(4-bromophenyl)- (ethoxyimino)methyl]-1'-[(2,4-dimethyl-3- pyridinyl)carbonyl]-4'methyl-1,4'- bipiperidine $\mathrm{N}$-oxide (SCH 351125): an orally bioavailable human CCR5 antagonist for the treatment of HIV infection. J. Med. Chem. 44: 3339-42 [PMID:11585437]

468. Papadakis KA, Prehn J, Nelson V, Cheng L, Binder SW, Ponath PD, Andrew DP and Targan SR. (2000) The role of thymus-expressed chemokine and its receptor CCR9 on lymphocytes in the regional specialization of the mucosal immune system. J. Immunol. 165: 5069-76 [PMID:11046037]

469. Park SH, Das BB, Casagrande F, Tian Y, Nothnagel HJ, Chu M, Kiefer H, Maier K, De Angelis AA and Marassi FM et al.. (2012) Structure of the chemokine receptor CXCR1 in phospholipid bilayers.Nature 491: 779-83 [PMID:23086146]

470. Parody TR and Stone MJ. (2004) High level expression, activation, and antagonism of CC chemokine receptors CCR2 and CCR3 in Chinese hamster ovary cells. Cytokine 27: 38-46 [PMID:15207250]

471. Pease J and Horuk R. (2012) Chemokine receptor antagonists. J. Med. Chem. 55: 9363-92 [PMID:22931505]

472. Pedersen F, Waschki B, Marwitz S, Goldmann T, Kirsten A, Malmgren A, Rabe KF, Uddin M and Watz H. (2018) Neutrophil extracellular trap formation is regulated by CXCR2 in COPD neutrophils. Eur. Respir. J. 51: [PMID:29449427]

473. Peng P, Chen H, Zhu Y, Wang Z, Li J, Luo RH, Wang J, Chen L, Yang LM and Jiang Het al.. (2018) Structure-Based Design of 1-Heteroaryl-1,3-propanediamine Derivatives as a Novel Series of CCChemokine Receptor 5 Antagonists. J. Med. Chem. 61: 9621-9636 [PMID:30234300]

474. Peters W, Dupuis M and Charo IF. (2000) A mechanism for the impaired IFN-gamma production in C-C chemokine receptor 2 (CCR2) knockout mice: role of CCR2 in linking the innate and adaptive immune responses. J. Immunol. 165: 7072-7 [PMID:11120836]

475. Petersen DC, Laten A, Zeier MD, Grimwood A, Rensburg EJ and Hayes VM. (2002) Novel mutations and SNPs identified in CCR2 using a new comprehensive denaturing gradient gel electrophoresis assay. Hum. Mutat. 20: 253-9 [PMID:12325020]

476. Petrek M, Drábek J, Kolek V, Zlámal J, Welsh KI, Bunce M, Weigl E and Du Bois R. (2000) CC chemokine receptor gene polymorphisms in Czech patients with pulmonary sarcoidosis. Am. J. Respir. Crit. Care Med. 162: 1000-3 [PMID:10988120]

477. Petrkova J, Cermakova Z, Drabek J, Lukl J and Petrek M. (2003) CC chemokine receptor (CCR)2 polymorphism in Czech patients with myocardial infarction. Immunol. Lett. 88: 53-5 [PMID:12853162]

478. Pope SM, Zimmermann N, Stringer KF, Karow ML and Rothenberg ME. (2005) The eotaxin chemokines and CCR3 are fundamental regulators of allergen-induced pulmonary eosinophilia. J. Immunol. 175: 534150 [PMID:16210640]

479. Power CA, Church DJ, Meyer A, Alouani S, Proudfoot AE, Clark-Lewis I, Sozzani S, Mantovani A and Wells TN. (1997) Cloning and characterization of a specific receptor for the novel CC chemokine MIP3alpha from lung dendritic cells. J. Exp. Med. 186: 825-35 [PMID:9294137]

480. Pozzobon T, Goldoni G, Viola A and Molon B. (2016) CXCR4 signaling in health and disease.Immunol. Lett. 177: 6-15 [PMID:27363619]

481. Pranzatelli MR, Tate ED, McGee NR, Travelstead AL, Ransohoff RM, Ness JM and Colliver JA. (2012) Key role of CXCL13/CXCR5 axis for cerebrospinal fluid B cell recruitment in pediatric OMS. J. Neuroimmunol. 243: 81-8 [PMID:22264765]

482. Prinz M, Heikenwalder M, Junt T, Schwarz P, Glatzel M, Heppner FL, Fu YX, Lipp M and Aguzzi A. (2003) Positioning of follicular dendritic cells within the spleen controls prion neuroinvasion. Nature 425: 957-62 [PMID:14562059]

483. Procopiou PA, Barrett JW, Barton NP, Begg M, Clapham D, Copley RC, Ford AJ, Graves RH, Hall DA and Hancock AP et al.. (2013) Synthesis and structure-activity relationships of indazole arylsulfonamides as allosteric CC-chemokine receptor 4 (CCR4) antagonists. J. Med. Chem. 56: 1946-60 [PMID:23409871]

484. Qi XW, Xia SH, Yin Y, Jin LF, Pu Y, Hua D and Wu HR. (2014) Expression features of CXCR5 and its ligand, CXCL13 associated with poor prognosis of advanced colorectal cancer. Eur Rev Med Pharmacol Sci 18: 1916-24 [PMID:25010623]

485. Qin S, Rottman JB, Myers P, Kassam N, Weinblatt M, Loetscher M, Koch AE, Moser B and Mackay CR. (1998) The chemokine receptors CXCR3 and CCR5 mark subsets of T cells associated with certain inflammatory reactions. J. Clin. Invest. 101: 746-54 [PMID:9466968]

486. Qu C, Edwards EW, Tacke F, Angeli V, Llodrá J, Sanchez-Schmitz G, Garin A, Haque NS, Peters W and van Rooijen N et al.. (2004) Role of CCR8 and other chemokine pathways in the migration of monocytederived dendritic cells to lymph nodes. J. Exp. Med. 200: 1231-41 [PMID:15534368]

487. Raghuwanshi SK, Su Y, Singh V, Haynes K, Richmond A and Richardson RM. (2012) The chemokine receptors CXCR1 and CXCR2 couple to distinct $G$ protein-coupled receptor kinases to mediate and 
regulate leukocyte functions. J. Immunol. 189: 2824-32 [PMID:22869904]

488. Randhawa S, Cho BS, Ghosh D, Sivina M, Koehrer S, Müschen M, Peled A, Davis RE, Konopleva M and Burger JA. (2016) Effects of pharmacological and genetic disruption of CXCR4 chemokine receptor function in B-cell acute lymphoblastic leukaemia. Br. J. Haematol. 174: 425-36 [PMID:27071778]

489. Raport CJ, Gosling J, Schweickart VL, Gray PW and Charo IF. (1996) Molecular cloning and functional characterization of a novel human CC chemokine receptor (CCR5) for RANTES, MIP-1beta, and MIP1alpha. J. Biol. Chem. 271: 17161-6 [PMID:8663314]

490. Raport CJ, Schweickart VL, Eddy RL, Shows TB and Gray PW. (1995) The orphan G-protein-coupled receptor-encoding gene V28 is closely related to genes for chemokine receptors and is expressed in lymphoid and neural tissues. Gene 163: 295-299 [PMID:7590284]

491. Rappert A, Biber K, Nolte C, Lipp M, Schubel A, Lu B, Gerard NP, Gerard C, Boddeke HW and Kettenmann H. (2002) Secondary lymphoid tissue chemokine (CCL21) activates CXCR3 to trigger a $\mathrm{Cl}$ current and chemotaxis in murine microglia. J. Immunol. 168: 3221-6 [PMID:11907075]

492. Rees S, Martin DP, Scott SV, Brown SH, Fraser N, O'Shaughnessy C and Beresford IJ. (2001) Development of a homogeneous MAP kinase reporter gene screen for the identification of agonists and antagonists at the CXCR1 chemokine receptor. J Biomol Screen 6: 19-27 [PMID:11679162]

493. Reid S, Ritchie A, Boring L, Gosling J, Cooper S, Hangoc G, Charo IF and Broxmeyer HE. (1999) Enhanced myeloid progenitor cell cycling and apoptosis in mice lacking the chemokine receptor, CCR2. Blood 93: 1524-33 [PMID:10029580]

494. Reif K, Ekland EH, Ohl L, Nakano H, Lipp M, Förster R and Cyster JG. (2002) Balanced responsiveness to chemoattractants from adjacent zones determines B-cell position. Nature 416: 94-9 [PMID:11882900]

495. Richardson RM, Marjoram RJ, Barak LS and Snyderman R. (2003) Role of the cytoplasmic tails of CXCR1 and CXCR2 in mediating leukocyte migration, activation, and regulation. $J$ Immuno/ 170: 2904-2911 [PMID:12626541]

496. Riol-Blanco L, Sánchez-Sánchez N, Torres A, Tejedor A, Narumiya S, Corbí AL, Sánchez-Mateos P and Rodríguez-Fernández JL. (2005) The chemokine receptor CCR7 activates in dendritic cells two signaling modules that independently regulate chemotaxis and migratory speed. J. Immunol. 174: 4070-80 [PMID:15778365]

497. Robben PM, LaRegina M, Kuziel WA and Sibley LD. (2005) Recruitment of Gr-1+ monocytes is essential for control of acute toxoplasmosis. J. Exp. Med. 201: 1761-9 [PMID:15928200]

498. Roos RS, Loetscher M, Legler DF, Clark-Lewis I, Baggiolini M and Moser B. (1997) Identification of CCR8, the receptor for the human CC chemokine I-309. J. Biol. Chem. 272: 17251-4 [PMID:9211859]

499. Rueda P, Balabanian K, Lagane B, Staropoli I, Chow K, Levoye A, Laguri C, Sadir R, Delaunay T and Izquierdo E et al.. (2008) The CXCL12gamma chemokine displays unprecedented structural and functional properties that make it a paradigm of chemoattractant proteins. PLoS ONE 3: e2543 [PMID:18648536]

500. Ruffing N, Sullivan N, Sharmeen L, Sodroski J and Wu L. (1998) CCR5 has an expanded ligand-binding repertoire and is the primary receptor used by MCP-2 on activated T cells. Cell. Immunol. 189: 160-8 [PMID:9790730]

501. Ryan BM, Robles AI, McClary AC, Haznadar M, Bowman ED, Pine SR, Brown D, Khan M, Shiraishi K and Kohno T et al.. (2015) Identification of a functional SNP in the 3'UTR of CXCR2 that is associated with reduced risk of lung cancer. Cancer Res. 75: 566-75 [PMID:25480945]

502. Sabroe I, Peck MJ, Van Keulen BJ, Jorritsma A, Simmons G, Clapham PR, Williams TJ and Pease JE. (2000) A small molecule antagonist of chemokine receptors CCR1 and CCR3. Potent inhibition of eosinophil function and CCR3-mediated HIV-1 entry. J. Biol. Chem. 275: 25985-92 [PMID:10854442]

503. Saito R, Onodera H, Tago H, Suzuki Y, Shimizu M, Matsumura Y, Kondo T and Itoyama Y. (2005) Altered expression of chemokine receptor CXCR5 on T cells of myasthenia gravis patients. J. Neuroimmunol. 170: 172-8 [PMID:16214223]

504. Salcedo R, Ponce ML, Young HA, Wasserman K, Ward JM, Kleinman HK, Oppenheim JJ and Murphy WJ. (2000) Human endothelial cells express CCR2 and respond to MCP-1: direct role of MCP-1 in angiogenesis and tumor progression. Blood 96: 34-40 [PMID:10891427]

505. Salcedo R, Wasserman K, Young HA, Grimm MC, Howard OM, Anver MR, Kleinman HK, Murphy WJ and Oppenheim JJ. (1999) Vascular endothelial growth factor and basic fibroblast growth factor induce expression of CXCR4 on human endothelial cells: In vivo neovascularization induced by stromal-derived factor-1alpha. Am. J. Pathol. 154: 1125-35 [PMID:10233851]

506. Salcedo R, Young HA, Ponce ML, Ward JM, Kleinman HK, Murphy WJ and Oppenheim JJ. (2001) Eotaxin (CCL11) induces in vivo angiogenic responses by human CCR3+ endothelial cells. J. Immunol. 166: 75718 [PMID:11390513]

507. Sallusto F, Lenig D, Förster R, Lipp M and Lanzavecchia A. (1999) Two subsets of memory T lymphocytes 
with distinct homing potentials and effector functions. Nature 401: 708-12 [PMID:10537110]

508. Sallusto F, Lenig D, Mackay CR and Lanzavecchia A. (1998) Flexible programs of chemokine receptor expression on human polarized T helper 1 and 2 lymphocytes. J. Exp. Med. 187: 875-83 [PMID:9500790]

509. Sallusto F, Palermo B, Lenig D, Miettinen M, Matikainen S, Julkunen I, Forster R, Burgstahler R, Lipp M and Lanzavecchia A. (1999) Distinct patterns and kinetics of chemokine production regulate dendritic cell function. Eur. J. Immunol. 29: 1617-25 [PMID:10359116]

510. Samson M, Labbe O, Mollereau C, Vassart G and Parmentier M. (1996) Molecular cloning and functional expression of a new human CC-chemokine receptor gene. Biochemistry 35: 3362-7 [PMID:8639485]

511. Samson M, Soularue P, Vassart $G$ and Parmentier M. (1996) The genes encoding the human CCchemokine receptors CC-CKR1 to CC-CKR5 (CMKBR1-CMKBR5) are clustered in the p21.3-p24 region of chromosome 3. Genomics 36: 522-526 [PMID:8884276]

512. Samson M, Stordeur P, Labbé O, Soularue P, Vassart G and Parmentier M. (1996) Molecular cloning and chromosomal mapping of a novel human gene, ChemR1, expressed in T lymphocytes and polymorphonuclear cells and encoding a putative chemokine receptor. Eur. J. Immunol. 26: 3021-8 [PMID:8977299]

513. Sanders SK, Crean SM, Boxer PA, Kellner D, LaRosa GJ and Hunt SW. (2000) Functional differences between monocyte chemotactic protein-1 receptor $A$ and monocyte chemotactic protein-1 receptor $B$ expressed in a Jurkat T cell. J Immunol 165: 4877-4883 [PMID:11046012]

514. Santella 3rd JB, Gardner DS, Duncia JV, Wu H, Dhar M, Cavallaro C, Tebben AJ, Carter PH, Barrish JC and Yarde $\mathrm{M}$ et al.. (2014) Discovery of the CCR1 antagonist, BMS-817399, for the treatment of rheumatoid arthritis. J. Med. Chem. 57: 7550-64 [PMID:25101488]

515. Sarafi MN, Garcia-Zepeda EA, MacLean JA, Charo IF and Luster AD. (1997) Murine monocyte chemoattractant protein (MCP)-5: a novel CC chemokine that is a structural and functional homologue of human MCP-1. J. Exp. Med. 185: 99-109 [PMID:8996246]

516. Sarau HM, Rush JA, Foley JJ, Brawner ME, Schmidt DB, White JR and Barnette MS. (1997) Characterization of functional chemokine receptors (CCR1 and CCR2) on EoL-3 cells: a model system to examine the role of chemokines in cell function. J. Pharmacol. Exp. Ther. 283: 411-8 [PMID:9336350]

517. Sato N, Ahuja SK, Quinones M, Kostecki V, Reddick RL, Melby PC, Kuziel WA and Ahuja SS. (2000) CC chemokine receptor (CCR)2 is required for langerhans cell migration and localization of T helper cell type 1 (Th1)-inducing dendritic cells. Absence of CCR2 shifts the Leishmania major-resistant phenotype to a susceptible state dominated by Th2 cytokines, b cell outgrowth, and sustained neutrophilic inflammation. J. Exp. Med. 192: 205-18 [PMID:10899907]

518. Sato N, Kuziel WA, Melby PC, Reddick RL, Kostecki V, Zhao W, Maeda N, Ahuja SK and Ahuja SS. (1999) Defects in the generation of IFN-gamma are overcome to control infection with Leishmania donovani in CC chemokine receptor (CCR) 5-, macrophage inflammatory protein-1 alpha-, or CCR2deficient mice. J. Immunol. 163: 5519-25 [PMID:10553079]

519. Sbrana S, Bevilacqua S, Buffa M, Spiller D, Parri MS, Gianetti J, De Filippis R and Clerico A. (2005) Postreperfusion changes of monocyte function in coronary blood after extracorporeal circulation. Cytometry $B$ Clin Cytom 65: 14-21 [PMID:15786508]

520. Scala S. (2015) Molecular Pathways: Targeting the CXCR4-CXCL12 Axis--Untapped Potential in the Tumor Microenvironment. Clin. Cancer Res. 21: 4278-85 [PMID:26199389]

521. Schaerli P, Willimann K, Lang AB, Lipp M, Loetscher P and Moser B. (2000) CXC chemokine receptor 5 expression defines follicular homing T cells with B cell helper function. J. Exp. Med. 192: 1553-62 [PMID:11104798]

522. Schmutz C, Hulme A, Burman A, Salmon M, Ashton B, Buckley C and Middleton J. (2005) Chemokine receptors in the rheumatoid synovium: upregulation of CXCR5. Arthritis Res. Ther. 7: R217-29 [PMID:15743468]

523. Schneider MA, Meingassner JG, Lipp M, Moore HD and Rot A. (2007) CCR7 is required for the in vivo function of CD4+ CD25+ regulatory T cells. J. Exp. Med. 204: 735-45 [PMID:17371928]

524. Schuh JM, Blease K and Hogaboam CM. (2002) The role of CC chemokine receptor 5 (CCR5) and RANTES/CCL5 during chronic fungal asthma in mice. FASEB J. 16: 228-30 [PMID:11744622]

525. Schuh JM, Power C, Proudfoot AE, Kunkel SL, Lukacs NW and Hogaboam CM. (2002) Airway hyperresponsiveness, but not airway remodeling, is attenuated during chronic pulmonary allergic responses to Aspergillus in CCR4-/- mice. FASEB J. 16: 1313-5 [PMID:12154006]

526. Schwarz MK and Wells TN. (1999) Interfering with chemokine networks--the hope for new therapeutics. Curr Opin Chem Bio/3: 407-17 [PMID:10419853]

527. Schweickart VL, Epp A, Raport CJ and Gray PW. (2000) CCR11 is a functional receptor for the monocyte chemoattractant protein family of chemokines. J. Biol. Chem. 75: 9550-9556 [PMID:10734104] 
528. Schweickart VL, Raport CJ, Godiska R, Byers MG, Eddy Jr RL, Shows TB and Gray PW. (1994) Cloning of human and mouse EBI1, a lymphoid-specific G-protein-coupled receptor encoded on human chromosome 17q12-q21.2. Genomics 23: 643-50 [PMID:7851893]

529. Scott HM and Flynn JL. (2002) Mycobacterium tuberculosis in chemokine receptor 2-deficient mice: influence of dose on disease progression. Infect. Immun. 70: 5946-54 [PMID:12379669]

530. Sehgal A, Ricks S, Boynton AL, Warrick J and Murphy GP. (1998) Molecular characterization of CXCR-4: a potential brain tumor-associated gene. J Surg Oncol69: 239-48 [PMID:9881942]

531. Semple BD, Kossmann T and Morganti-Kossmann MC. (2010) Role of chemokines in CNS health and pathology: a focus on the CCL2/CCR2 and CXCL8/CXCR2 networks. J. Cereb. Blood Flow Metab. 30: 459-73 [PMID:19904283]

532. Seth S, Oberdörfer L, Hyde R, Hoff K, Thies V, Worbs T, Schmitz S and Förster R. (2011) CCR7 essentially contributes to the homing of plasmacytoid dendritic cells to lymph nodes under steady-state as well as inflammatory conditions. J. Immunol. 186: 3364-72 [PMID:21296980]

533. Shan L, Qiao X, Oldham E, Catron D, Kaminski H, Lundell D, Zlotnik A, Gustafson E and Hedrick JA. (2000) Identification of viral macrophage inflammatory protein (vMIP)-II as a ligand for GPR5/XCR1. Biochem Biophys Res Commun268: 938-941 [PMID:10679309]

534. Shen F, Zhang Y, Jernigan DL, Feng X, Yan J, Garcia FU, Meucci O, Salvino JM and Fatatis A. (2016) Novel Small-Molecule CX3CR1 Antagonist Impairs Metastatic Seeding and Colonization of Breast Cancer Cells. Mol. Cancer Res. 14: 518-27 [PMID:27001765]

535. Shimada T, Matsumoto M, Tatsumi Y, Kanamaru A and Akira S. (1998) A novel lipopolysaccharide inducible C-C chemokine receptor related gene in murine macrophages. FEBS Lett. 425: 490-4 [PMID:9563519]

536. Shimaoka T, Nakayama T, Fukumoto N, Kume N, Takahashi S, Yamaguchi J, Minami M, Hayashida K, Kita T and Ohsumi J et al.. (2004) Cell surface-anchored SR-PSOX/CXC chemokine ligand 16 mediates firm adhesion of CXC chemokine receptor 6-expressing cells. J. Leukoc. Biol.75: 267-74 [PMID:14634054]

537. Shitara K, Nakamura K, Hosaka E, Tanaka A and Koike M. (2009) Monoclonal antibodies which preferentially bind to chemokine receptors, used for immunotherapy, as antiinflammatory, aniticarcinogenic agents and for prophylaxis of respiratory system disorders or antiallergens. Patent number: US7504104.

538. Siebert H, Sachse A, Kuziel WA, Maeda N and Brück W. (2000) The chemokine receptor CCR2 is involved in macrophage recruitment to the injured peripheral nervous system. J. Neuroimmunol.110: 17785 [PMID:11024548]

539. Sierro F, Biben C, Martínez-Muñoz L, Mellado M, Ransohoff RM, Li M, Woehl B, Leung H, Groom J, Batten M, Harvey RP, Martínez-A C, Mackay CR and Mackay F. (2007) Disrupted cardiac development but normal hematopoiesis in mice deficient in the second CXCL12/SDF-1 receptor, CXCR7. Proc. Natl. Acad. Sci. U.S.A. 104: 14759-64 [PMID:17804806]

540. Singh KK, Hughes MD, Chen J and Spector SA. (2005) Genetic polymorphisms in CX3CR1 predict HIV-1 disease progression in children independently of CD4+ lymphocyte count and HIV-1 RNA load. J. Infect. Dis. 191: 1971-80 [PMID:15871132]

541. Singh S, Singh R, Singh UP, Rai SN, Novakovic KR, Chung LW, Didier PJ, Grizzle WE and Lillard Jr JW. (2009) Clinical and biological significance of CXCR5 expressed by prostate cancer specimens and cell lines. Int. J. Cancer 125: 2288-95 [PMID:19610059]

542. Skerlj RT, Bridger GJ, Kaller A, McEachern EJ, Crawford JB, Zhou Y, Atsma B, Langille J, Nan S and Veale $D$ et al.. (2010) Discovery of novel small molecule orally bioavailable C-X-C chemokine receptor 4 antagonists that are potent inhibitors of T-tropic (X4) HIV-1 replication. J. Med. Chem. 53: 3376-88 [PMID:20297846]

543. Smith MW, Dean M, Carrington M, Winkler C, Huttley GA, Lomb DA, Goedert JJ, O'Brien TR, Jacobson LP and Kaslow $R$ et al.. (1997) Contrasting genetic influence of CCR2 and CCR5 variants on HIV-1 infection and disease progression. Hemophilia Growth and Development Study (HGDS), Multicenter AIDS Cohort Study (MACS), Multicenter Hemophilia Cohort Study (MHCS), San Francisco City Cohort (SFCC), ALIVE Study. Science 277: 959-65 [PMID:9252328]

544. Solari R and Pease JE. (2015) Targeting chemokine receptors in disease--a case study of CCR4.Eur. J. Pharmacol. 763: 169-77 [PMID:25981299]

545. Soler D, Humphreys TL, Spinola SM and Campbell JJ. (2003) CCR4 versus CCR10 in human cutaneous TH lymphocyte trafficking. Blood 101: 1677-82 [PMID:12406880]

546. Somovilla-Crespo B, Alfonso-Pérez M, Cuesta-Mateos C, Carballo-de Dios C, Beltrán AE, Terrón F, Pérez-Villar JJ, Gamallo-Amat C, Pérez-Chacón G and Fernández-Ruiz E et al.. (2013) Anti-CCR7 therapy exerts a potent anti-tumor activity in a xenograft model of human mantle cell lymphoma. $J$ Hematol Oncol 6: 89 [PMID:24305507] 
547. Song H, Tong D, Cha Z and Bai J. (2012) C-X-C chemokine receptor type 5 gene polymorphisms are associated with non-Hodgkin lymphoma. Mol. Biol. Rep. 39: 8629-35 [PMID:22707196]

548. Sordi V, Bianchi G, Buracchi C, Mercalli A, Marchesi F, D'Amico G, Yang CH, Luini W, Vecchi A and Mantovani A et al.. (2006) Differential effects of immunosuppressive drugs on chemokine receptor CCR7 in human monocyte-derived dendritic cells: selective upregulation by rapamycin. Transplantation 82: 82634 [PMID:17006331]

549. Soto H, Wang W, Strieter RM, Copeland NG, Gilbert DJ, Jenkins NA, Hedrick J and Zlotnik A. (1998) The CC chemokine 6Ckine binds the CXC chemokine receptor CXCR3. Proc. Natl. Acad. Sci. U.S.A.95: 820510 [PMID:9653165]

550. Southern C, Cook JM, Neetoo-Isseljee Z, Taylor DL, Kettleborough CA, Merritt A, Bassoni DL, Raab WJ, Quinn E and Wehrman TS et al.. (2013) Screening $\beta$-Arrestin Recruitment for the Identification of Natural Ligands for Orphan G-Protein-Coupled Receptors. J Biomol Screen 18: 599-609 [PMID:23396314]

551. Sperveslage J, Frank S, Heneweer C, Egberts J, Schniewind B, Buchholz M, Bergmann F, Giese N, Munding J and Hahn SA et al.. (2012) Lack of CCR7 expression is rate limiting for lymphatic spread of pancreatic ductal adenocarcinoma. Int. J. Cancer 131: E371-81 [PMID:22020953]

552. Spinetti G, Bernardini G, Camarda G, Mangoni A, Santoni A, Capogrossi MC and Napolitano M. (2003) The chemokine receptor CCR8 mediates rescue from dexamethasone-induced apoptosis via an ERKdependent pathway. J Leukoc Biol 73: 201-207 [PMID:12525579]

553. Steele CW, Karim SA, Foth M, Rishi L, Leach JD, Porter RJ, Nixon C, Jeffry Evans TR, Carter CR and Nibbs RJ et al.. (2015) CXCR2 inhibition suppresses acute and chronic pancreatic inflammation.J. Pathol. 237: 85-97 [PMID:25950520]

554. Stein JV, Soriano SF, M'rini C, Nombela-Arrieta C, de Buitrago GG, Rodríguez-Frade JM, Mellado M, Girard JP and Martínez-A C. (2003) CCR7-mediated physiological lymphocyte homing involves activation of a tyrosine kinase pathway. Blood 101: 38-44 [PMID:12393730]

555. Stein O, Dabach Y, Ben-Naim M, Halperin G, Charo IF and Stein Y. (2003) In CCR2-/- mice monocyte recruitment and egress of LDL cholesterol in vivo is impaired. Biochem Biophys Res Commun300: 477481 [PMID:12504109]

556. Stemmler S, Arinir U, Klein W, Rohde G, Hoffjan S, Wirkus N, Reinitz-Rademacher K, Bufe A, SchultzeWerninghaus $G$ and Epplen JT. (2005) Association of interleukin-8 receptor alpha polymorphisms with chronic obstructive pulmonary disease and asthma. Genes Immun 6: 225-230 [PMID:15772681]

557. Stock AT, Smith JM and Carbone FR. (2014) Type I IFN suppresses Cxcr2 driven neutrophil recruitment into the sensory ganglia during viral infection. J. Exp. Med. 211: 751-9 [PMID:24752295]

558. Strizki JM, Tremblay C, Xu S, Wojcik L, Wagner N, Gonsiorek W, Hipkin RW, Chou CC, Pugliese-Sivo C and Xiao $Y$ et al.. (2005) Discovery and characterization of vicriviroc (SCH 417690), a CCR5 antagonist with potent activity against human immunodeficiency virus type 1. Antimicrob. Agents Chemother. 49: 4911-9 [PMID:16304152]

559. Stuart MJ, Corrigan F and Baune BT. (2014) Knockout of CXCR5 increases the population of immature neural cells and decreases proliferation in the hippocampal dentate gyrus. $J$ Neuroinflammation 11: 31 [PMID:24528805]

560. Stumm RK, Zhou C, Ara T, Lazarini F, Dubois-Dalcq M, Nagasawa T, Höllt V and Schulz S. (2003) CXCR4 regulates interneuron migration in the developing neocortex. J. Neurosci. 23: 5123-30 [PMID:12832536]

561. Sturm A, Baumgart DC, d'Heureuse JH, Hotz A, Wiedenmann B and Dignass AU. (2005) CXCL8 modulates human intestinal epithelial cells through a CXCR1 dependent pathway. Cytokine 29: 42-8 [PMID:15579377]

562. Su B, Sun G, Lu D, Xiao J, Hu F, Chakraborty R, Deka R and Jin L. (2000) Distribution of three HIV-1 resistance-conferring polymorphisms (SDF1-3'A, CCR2-641, and CCR5-delta32) in global populations. Eur. J. Hum. Genet. 8: 975-9 [PMID:11175286]

563. Su SB, Mukaida N, Wang J, Nomura H and Matsushima K. (1996) Preparation of specific polyclonal antibodies to a C-C chemokine receptor, CCR1, and determination of CCR1 expression on various types of leukocytes. J Leukoc Biol 60: 658-666 [PMID:8929558]

564. Sullivan SK, McGrath DA, Grigoriadis D and Bacon KB. (1999) Pharmacological and signaling analysis of human chemokine receptor CCR-7 stably expressed in HEK-293 cells: high-affinity binding of recombinant ligands MIP-3beta and SLC stimulates multiple signaling cascades. Biochem Biophys Res Commun263: 685-690 [PMID:10512740]

565. Sun Y, Cheng Z, Ma L and Pei G. (2002) Beta-arrestin2 is critically involved in CXCR4-mediated chemotaxis, and this is mediated by its enhancement of p38 MAPK activation. J. Biol. Chem. 277: 49212-9 [PMID:12370187] 
566. Svensson M, Marsal J, Ericsson A, Carramolino L, Brodén T, Márquez G and Agace WW. (2002) CCL25 mediates the localization of recently activated CD8alphabeta(+) lymphocytes to the small-intestinal mucosa. J. Clin. Invest. 110: 1113-21 [PMID:12393847]

567. Szalai C, Duba J, Prohászka Z, Kalina A, Szabó T, Nagy B, Horváth L and Császár A. (2001) Involvement of polymorphisms in the chemokine system in the susceptibility for coronary artery disease (CAD). Coincidence of elevated $L p(a)$ and MCP-1 -2518 G/G genotype in CAD patients. Atherosclerosis 158: 2339 [PMID:11500196]

568. Szpakowska M, Meyrath M, Reynders N, Counson M, Hanson J, Steyaert J and Chevigné A. (2018) Mutational analysis of the extracellular disulphide bridges of the atypical chemokine receptor ACKR3/CXCR7 uncovers multiple binding and activation modes for its chemokine and endogenous nonchemokine agonists. Biochem. Pharmacol. 153: 299-309 [PMID:29530506]

569. Sáez de Guinoa J, Barrio L, Mellado M and Carrasco YR. (2011) CXCL13/CXCR5 signaling enhances BCR-triggered B-cell activation by shaping cell dynamics. Blood 118: 1560-9 [PMID:21659539]

570. Sánchez-Sánchez N, Riol-Blanco L, de la Rosa G, Puig-Kröger A, García-Bordas J, Martín D, Longo N, Cuadrado A, Cabañas C and Corbí AL et al.. (2004) Chemokine receptor CCR7 induces intracellular signaling that inhibits apoptosis of mature dendritic cells. Blood 104: 619-25 [PMID:15059845]

571. Sørensen TL, Roed H and Sellebjerg F. (2002) Chemokine receptor expression on B cells and effect of interferon-beta in multiple sclerosis. J. Neuroimmunol. 122: 125-31 [PMID:11777551]

572. Takata H, Tomiyama H, Fujiwara M, Kobayashi N and Takiguchi M. (2004) Cutting edge: expression of chemokine receptor CXCR1 on human effector CD8+ T cells. J. Immunol. 173: 2231-5 [PMID:15294933]

573. Tamamura H, Xu Y, Hattori T, Zhang X, Arakaki R, Kanbara K, Omagari A, Otaka A, Ibuka T and Yamamoto $\mathrm{N}$ et al.. (1998) A low-molecular-weight inhibitor against the chemokine receptor CXCR4: a strong anti-HIV peptide T140. Biochem. Biophys. Res. Commun. 253: 877-82 [PMID:9918823]

574. Tan Q, Zhu Y, Li J, Chen Z, Han GW, Kufareva I, Li T, Ma L, Fenalti G and Li æt al.. (2013) Structure of the CCR5 chemokine receptor-HIV entry inhibitor maraviroc complex. Science 341: 1387-90 [PMID:24030490]

575. Tanaka S, Green SR and Quehenberger O. (2002) Differential expression of the isoforms for the monocyte chemoattractant protein-1 receptor, CCR2, in monocytes. Biochem. Biophys. Res. Commun. 290: 73-80 [PMID:11779135]

576. Tancevski I, Nairz M, Duwensee K, Auer K, Schroll A, Heim C, Feistritzer C, Hoefer J, Gerner RR and Moschen AR et al.. (2014) Fibrates ameliorate the course of bacterial sepsis by promoting neutrophil recruitment via CXCR2. EMBO Mol Med6: 810-20 [PMID:24755316]

577. Tarzami ST, Miao W, Mani K, Lopez L, Factor SM, Berman JW and Kitsis RN. (2003) Opposing effects mediated by the chemokine receptor CXCR2 on myocardial ischemia-reperfusion injury: recruitment of potentially damaging neutrophils and direct myocardial protection. Circulation 108: 2387-2392 [PMID:14568904]

578. Teupser D, Pavlides S, Tan M, Gutierrez-Ramos JC, Kolbeck R and Breslow JL. (2004) Major reduction of atherosclerosis in fractalkine (CX3CL1)-deficient mice is at the brachiocephalic artery, not the aortic root. Proc. Natl. Acad. Sci. U.S.A. 101: 17795-800 [PMID:15596719]

579. Thoma G, Streiff MB, Kovarik J, Glickman F, Wagner T, Beerli C and Zerwes HG. (2008) Orally bioavailable isothioureas block function of the chemokine receptor CXCR4 in vitro and in vivo. J. Med. Chem. 51: 7915-20 [PMID:19053768]

580. Thomas SY, Hou R, Boyson JE, Means TK, Hess C, Olson DP, Strominger JL, Brenner MB, Gumperz JE and Wilson SB et al.. (2003) CD1d-restricted NKT cells express a chemokine receptor profile indicative of Th1-type inflammatory homing cells. J. Immunol. 171: 2571-80 [PMID:12928408]

581. Tiffany HL, Lautens LL, Gao JL, Pease J, Locati M, Combadiere C, Modi W, Bonner TI and Murphy PM. (1997) Identification of CCR8: a human monocyte and thymus receptor for the CC chemokine I-309. J. Exp. Med. 186: 165-70 [PMID:9207005]

582. Topham PS, Csizmadia V, Soler D, Hines D, Gerard CJ, Salant DJ and Hancock WW. (1999) Lack of chemokine receptor CCR1 enhances Th1 responses and glomerular injury during nephrotoxic nephritis. $J$. Clin. Invest. 104: 1549-57 [PMID:10587518]

583. Townson JR and Nibbs RJ. (2002) Characterization of mouse CCX-CKR, a receptor for the lymphocyteattracting chemokines TECK/mCCL25, SLC/mCCL21 and MIP-3beta/mCCL19: comparison to human CCX-CKR. Eur. J. Immunol. 32: 1230-41 [PMID:11981810]

584. Traynor TR, Kuziel WA, Toews GB and Huffnagle GB. (2000) CCR2 expression determines T1 versus T2 polarization during pulmonary Cryptococcus neoformans infection. J. Immunol. 164: 2021-7 [PMID:10657654]

585. Troyer JL, Nelson GW, Lautenberger JA, Chinn L, McIntosh C, Johnson RC, Sezgin E, Kessing B, 
Malasky M and Hendrickson SL et al.. (2011) Genome-wide association study implicates PARD3B-based AIDS restriction. J. Infect. Dis. 203: 1491-502 [PMID:21502085]

586. Uddin M, Betts C, Robinson I, Malmgren A and Humfrey C. (2017) The chemokine CXCR2 antagonist (AZD5069) preserves neutrophil-mediated host immunity in non-human primates. Haematologica 102: e65-e68 [PMID:27742769]

587. Uddin M, Watz H, Malmgren A and Pedersen F. (2019) NETopathic Inflammation in Chronic Obstructive Pulmonary Disease and Severe Asthma. Front Immunol 10: 47 [PMID:30804927]

588. Uehara S, Grinberg A, Farber JM and Love PE. (2002) A role for CCR9 in T lymphocyte development and migration. J. Immunol. 168: 2811-9 [PMID:11884450]

589. Ueno T, Saito F, Gray DH, Kuse S, Hieshima K, Nakano H, Kakiuchi T, Lipp M, Boyd RL and Takahama Y. (2004) CCR7 signals are essential for cortex-medulla migration of developing thymocytes. J. Exp. Med. 200: 493-505 [PMID:15302902]

590. Uguccioni M, Mackay CR, Ochensberger B, Loetscher P, Rhis S, LaRosa GJ, Rao P, Ponath PD, Baggiolini M and Dahinden CA. (1997) High expression of the chemokine receptor CCR3 in human blood basophils. Role in activation by eotaxin, MCP-4, and other chemokines. J. Clin. Invest. 100: 1137-43 [PMID:9276730]

591. Unutmaz D, Xiang W, Sunshine MJ, Campbell J, Butcher E and Littman DR. (2000) The primate lentiviral receptor Bonzo/STRL33 is coordinately regulated with CCR5 and its expression pattern is conserved between human and mouse. J. Immunol. 165: 3284-92 [PMID:10975845]

592. Valdes AM, Wolfe ML, O'Brien EJ, Spurr NK, Gefter W, Rut A, Groot PH and Rader DJ. (2002) Val64lle polymorphism in the $\mathrm{C}-\mathrm{C}$ chemokine receptor 2 is associated with reduced coronary artery calcification. Arterioscler. Thromb. Vasc. Biol. 22: 1924-8 [PMID:12426226]

593. van Deventer HW, O'Connor Jr W, Brickey WJ, Aris RM, Ting JP and Serody JS. (2005) C-C chemokine receptor 5 on stromal cells promotes pulmonary metastasis. Cancer Res. 65: 3374-9 [PMID:15833871]

594. Vargas AE, da Silva MA, Silla $L$ and Chies JA. (2005) Polymorphisms of chemokine receptors and eNOS in Brazilian patients with sickle cell disease. Tissue Antigens 66: 683-90 [PMID:16305685]

595. Varona R, Villares R, Carramolino L, Goya I, Zaballos A, Gutiérrez J, Torres M, Martínez-A C and Márquez G. (2001) CCR6-deficient mice have impaired leukocyte homeostasis and altered contact hypersensitivity and delayed-type hypersensitivity responses. J. Clin. Invest. 107: R37-45 [PMID:11254677]

596. Varona R, Zaballos A, Gutierrez J, Martín P, Roncal F, Albar JP, Ardavin C and Marquez G. (1998) Molecular cloning, functional characterization and mRNA expression analysis of the murine chemokine receptor CCR6 and its specific ligand MIP-3alpha. FEBS Lett 440: 188-194 [PMID:9862452]

597. Vasilescu A, Terashima Y, Enomoto M, Heath S, Poonpiriya V, Gatanaga H, Do H, Diop G, Hirtzig T and Auewarakul $\mathrm{P}$ et al.. (2007) A haplotype of the human CXCR1 gene protective against rapid disease progression in HIV-1+ patients. Proc. Natl. Acad. Sci. U.S.A. 104: 3354-9 [PMID:17360650]

598. Voigt I, Camacho SA, de Boer BA, Lipp M, Förster R and Berek C. (2000) CXCR5-deficient mice develop functional germinal centers in the splenic T cell zone. Eur. J. Immunol. 30: 560-7 [PMID:10671212]

599. Wacker DA, Santella 3rd JB, Gardner DS, Varnes JG, Estrella M, DeLucca GV, Ko SS, Tanabe K, Watson PS and Welch PK et al.. (2002) CCR3 antagonists: a potential new therapy for the treatment of asthma. Discovery and structure-activity relationships. Bioorg. Med. Chem. Lett. 12: 1785-9 [PMID:12067561]

600. Waeckel L, Mallat Z, Potteaux S, Combadière C, Clergue M, Duriez M, Bao L, Gerard C, Rollins BJ and Tedgui A et al.. (2005) Impairment in postischemic neovascularization in mice lacking the CXC chemokine receptor 3. Circ. Res. 96: 576-82 [PMID:15718500]

601. Wakasugi K and Schimmel P. (1999) Two distinct cytokines released from a human aminoacyl-tRNA synthetase. Science 284: 147-51 [PMID:10102815]

602. Walenkamp AME, Lapa C, Herrmann K and Wester HJ. (2017) CXCR4 Ligands: The Next Big Hit?J. Nucl. Med. 58: 77S-82S [PMID:28864616]

603. Walker SR, Aboka A, Ogagan PD and Barksdale Jr EM. (2005) Murine neuroblastoma attenuates dendritic cell cysteine cysteine receptor 7 (CCR7) expression. J. Pediatr. Surg. 40: 983-7 [PMID:15991182]

604. Walters MJ, Wang Y, Lai N, Baumgart T, Zhao BN, Dairaghi DJ, Bekker P, Ertl LS, Penfold ME and Jaen JC et al.. (2010) Characterization of CCX282-B, an orally bioavailable antagonist of the CCR9 chemokine receptor, for treatment of inflammatory bowel disease. J. Pharmacol. Exp. Ther. 335: 61-9 [PMID:20660125]

605. Wan Y, Jakway JP, Qiu H, Shah H, Garlisi CG, Tian F, Ting P, Hesk D, Egan RW and Billah MNet al.. (2002) Identification of full, partial and inverse CC chemokine receptor 3 agonists using [35S]GTPgammaS binding. Eur. J. Pharmacol. 456: 1-10 [PMID:12450563]

606. Wang W, Soto H, Oldham ER, Buchanan ME, Homey B, Catron D, Jenkins N, Copeland NG, Gilbert DJ and Nguyen $\mathrm{N}$ et al.. (2000) Identification of a novel chemokine (CCL28), which binds CCR10 (GPR2).J. 
Biol. Chem. 275: 22313-23 [PMID:10781587]

607. Wang X, Li X, Schmidt DB, Foley JJ, Barone FC, Ames RS and Sarau HM. (2000) Identification and molecular characterization of rat CXCR3: receptor expression and interferon-inducible protein-10 binding are increased in focal stroke. Mol. Pharmacol. 57: 1190-8 [PMID:10825390]

608. Wang Y, Zhang Y, Yang X, Han W, Liu Y, Xu Q, Zhao R, Di C, Song Q and Ma D. (2006) Chemokine-like factor 1 is a functional ligand for CC chemokine receptor 4 (CCR4). Life Sci. 78: 614-21 [PMID:16137713]

609. Wang Z, Sun J, Feng Y, Tian X, Wang B and Zhou Y. (2016) Oncogenic roles and drug target of CXCR4/CXCL12 axis in lung cancer and cancer stem cell. Tumour Biol. 37: 8515-28 [PMID:27079871]

610. Warmington KS, Boring L, Ruth JH, Sonstein J, Hogaboam CM, Curtis JL, Kunkel SL, Charo IR and Chensue SW. (1999) Effect of C-C chemokine receptor 2 (CCR2) knockout on type-2 (schistosomal antigen-elicited) pulmonary granuloma formation: analysis of cellular recruitment and cytokine responses. Am. J. Pathol. 154: 1407-16 [PMID:10329593]

611. Watts AO, Verkaar F, van der Lee MM, Timmerman CA, Kuijer M, van Offenbeek J, van Lith LH, Smit MJ, Leurs R and Zaman GJ et al.. (2013) $\beta$-Arrestin recruitment and $G$ protein signaling by the atypical human chemokine decoy receptor CCX-CKR. J. Biol. Chem. 288: 7169-81 [PMID:23341447]

612. Watz H, Uddin M, Pedersen F, Kirsten A, Goldmann T, Stellmacher F, Groth E, Larsson B, Böttcher G and Malmgren A et al.. (2017) Effects of the CXCR2 antagonist AZD5069 on lung neutrophil recruitment in asthma. Pulm Pharmacol Ther 45: 121-123 [PMID:28549850]

613. Waugh DJ and Wilson C. (2008) The interleukin-8 pathway in cancer.Clin. Cancer Res. 14: 6735-41 [PMID:18980965]

614. Weisberg SP, Hunter D, Huber R, Lemieux J, Slaymaker S, Vaddi K, Charo I, Leibel RL and Ferrante Jr AW. (2006) CCR2 modulates inflammatory and metabolic effects of high-fat feeding. J. Clin. Invest.116: 115-24 [PMID:16341265]

615. Weissman D, Rabin RL, Arthos J, Rubbert A, Dybul M, Swofford R, Venkatesan S, Farber JM and Fauci AS. (1997) Macrophage-tropic HIV and SIV envelope proteins induce a signal through the CCR5 chemokine receptor. Nature 389: $981-5$ [PMID:9353123]

616. Wendland M, Willenzon S, Kocks J, Davalos-Misslitz AC, Hammerschmidt SI, Schumann K, Kremmer E, Sixt M, Hoffmeyer A and Pabst $O$ et al.. (2011) Lymph node T cell homeostasis relies on steady state homing of dendritic cells. Immunity 35: 945-57 [PMID:22195748]

617. Wendt E and Keshav S. (2015) CCR9 antagonism: potential in the treatment of Inflammatory Bowel Disease. Clin Exp Gastroenterol 8: 119-30 [PMID:25897254]

618. Weng Y, Siciliano SJ, Waldburger KE, Sirotina-Meisher A, Staruch MJ, Daugherty BL, Gould SL, Springer MS and DeMartino JA. (1998) Binding and functional properties of recombinant and endogenous CXCR3 chemokine receptors. J. Biol. Chem. 273: 18288-91 [PMID:9660793]

619. Westby M and van der Ryst E. (2005) CCR5 antagonists: host-targeted antivirals for the treatment of HIV infection. Antivir. Chem. Chemother. 16: 339-54 [PMID:16329283]

620. White JR, Lee JM, Young PR, Hertzberg RP, Jurewicz AJ, Chaikin MA, Widdowson K, Foley JJ, Martin LD and Griswold DE et al.. (1998) Identification of a potent, selective non-peptide CXCR2 antagonist that inhibits interleukin-8-induced neutrophil migration. J. Biol. Chem. 273: 10095-8 [PMID:9553055]

621. Widney DP, Hu Y, Foreman-Wykert AK, Bui KC, Nguyen TT, Lu B, Gerard C, Miller JF and Smith JB. (2005) CXCR3 and its ligands participate in the host response to Bordetella bronchiseptica infection of the mouse respiratory tract but are not required for clearance of bacteria from the lung. Infect Immun 73: 485493 [PMID:15618188]

622. Wieser F, Dogan S, Klingel K, Diedrich K, Taylor RN and Hornung D. (2005) Expression and regulation of CCR1 in peritoneal macrophages from women with and without endometriosis. Fertil. Steril. 83: 1878-81 [PMID:15950672]

623. Wilbanks A, Zondlo SC, Murphy K, Mak S, Soler D, Langdon P, Andrew DP, Wu L and Briskin M. (2001) Expression cloning of the STRL33/BONZO/TYMSTRligand reveals elements of CC, CXC, and CX3C chemokines. J. Immunol. 166: 5145-54 [PMID:11290797]

624. Williams IR. (2004) Chemokine receptors and leukocyte trafficking in the mucosal immune system. Immunol. Res. 29: 283-92 [PMID:15181289]

625. Wilson RJ, Jecs E, Miller EJ, Nguyen HH, Tahirovic YA, Truax VM, Kim MB, Kuo KM, Wang T and Sum CS et al.. (2018) Synthesis and SAR of 1,2,3,4-Tetrahydroisoquinoline-Based CXCR4 Antagonists.ACS Med Chem Lett 9: 17-22 [PMID:29348805]

626. Wilson S, Wilkinson $G$ and Milligan G. (2005) The CXCR1 and CXCR2 receptors form constitutive homoand heterodimers selectively and with equal apparent affinities. J. Biol. Chem. 280: 28663-74 [PMID:15946947]

627. Wisniewski T, Bayne E, Flanagan J, Shao Q, Wnek R, Matheravidathu S, Fischer P, Forrest MJ, Peterson 
$L$ and Song $X$ et al.. (2010) Assessment of chemokine receptor function on monocytes in whole blood: In vitro and ex vivo evaluations of a CCR2 antagonist. J. Immunol. Methods 352: 101-10 [PMID:19913021]

628. Wolf M, Delgado MB, Jones SA, Dewald B, Clark-Lewis I and Baggiolini M. (1998) Granulocyte chemotactic protein 2 acts via both IL-8 receptors, CXCR1 and CXCR2. Eur. J. Immunol. 28: 164-70 [PMID:9485196]

629. Wong LM, Myers SJ, Tsou CL, Gosling J, Arai H and Charo IF. (1997) Organization and differential expression of the human monocyte chemoattractant protein 1 receptor gene. Evidence for the role of the carboxyl-terminal tail in receptor trafficking. J. Biol. Chem. 272: 1038-45 [PMID:8995400]

630. Wong ML, Xin WW and Duman RS. (1996) Rat LCR1: cloning and cellular distribution of a putative chemokine receptor in brain. Mol. Psychiatry 1: 133-40 [PMID:9118323]

631. Wong RS, Bodart V, Metz M, Labrecque J, Bridger G and Fricker SP. (2008) Comparison of the potential multiple binding modes of bicyclam, monocylam, and noncyclam small-molecule CXC chemokine receptor 4 inhibitors. Mol. Pharmacol. 74: 1485-95 [PMID:18768385]

632. Worbs T, Mempel TR, Bölter J, von Andrian UH and Förster R. (2007) CCR7 ligands stimulate the intranodal motility of T lymphocytes in vivo. J. Exp. Med. 204: 489-95 [PMID:17325198]

633. Wu B, Chien EY, Mol CD, Fenalti G, Liu W, Katritch V, Abagyan R, Brooun A, Wells P and Bi FCet al.. (2010) Structures of the CXCR4 chemokine GPCR with small-molecule and cyclic peptide antagonists. Science 330: 1066-71 [PMID:20929726]

634. Wu F, Zhao Y, Jiao T, Shi D, Zhu X, Zhang M, Shi M and Zhou H. (2015) CXCR2 is essential for cerebral endothelial activation and leukocyte recruitment during neuroinflammation. $J$ Neuroinflammation 12: 98 [PMID:25990934]

635. Wu KJ, Yu SJ, Shia KS, Wu CH, Song JS, Kuan HH, Yeh KC, Chen CT, Bae E and Wang Y. (2017) A Novel CXCR4 Antagonist CX549 Induces Neuroprotection in Stroke Brain. Cell Transplant 26: 571-583 [PMID:27938478]

636. Wu L, Ruffing N, Shi X, Newman W, Soler D, Mackay CR and Qin S. (1996) Discrete steps in binding and signaling of interleukin-8 with its receptor. J. Biol. Chem. 271: 31202-9 [PMID:8940121]

637. Wu MT and Hwang ST. (2002) CXCR5-transduced bone marrow-derived dendritic cells traffic to B cell zones of lymph nodes and modify antigen-specific immune responses. J. Immunol. 168: 5096-102 [PMID:11994462]

638. Wurbel MA, Malissen M, Guy-Grand D, Meffre E, Nussenzweig MC, Richelme M, Carrier A and Malissen B. (2001) Mice lacking the CCR9 CC-chemokine receptor show a mild impairment of early T-and B-cell development and a reduction in T-cell receptor gammadelta(+) gut intraepithelial lymphocytes. Blood 98 : 2626-32 [PMID:11675330]

639. Wurth R, Tarn K, Jernigan D, Fernandez SV, Cristofanilli M, Fatatis A and Meucci O. (2015) A Preclinical Model of Inflammatory Breast Cancer to Study the Involvement of CXCR4 and ACKR3 in the Metastatic Process. Trans/ Oncol 8: 358-67 [PMID:26500026]

640. Wuyts A, Proost P, Lenaerts JP, Ben-Baruch A, Van Damme J and Wang JM. (1998) Differential usage of the CXC chemokine receptors 1 and 2 by interleukin-8, granulocyte chemotactic protein-2 and epithelialcell-derived neutrophil attractant-78. Eur. J. Biochem. 255: 67-73 [PMID:9692902]

641. Wuyts A, Van Osselaer N, Haelens A, Samson I, Herdewijn P, Ben-Baruch A, Oppenheim JJ, Proost P and Van Damme J. (1997) Characterization of synthetic human granulocyte chemotactic protein 2: usage of chemokine receptors CXCR1 and CXCR2 and in vivo inflammatory properties. Biochemistry 36: 271623 [PMID:9054580]

642. Xanthou G, Duchesnes CE, Williams TJ and Pease JE. (2003) CCR3 functional responses are regulated by both CXCR3 and its ligands CXCL9, CXCL10 and CXCL11. Eur. J. Immunol. 33: 2241-50 [PMID:12884299]

643. Xing J, Li X, Sui J, Cao G and Fu C. (2014) C-X-C chemokine receptor type 5 gene polymorphism affects gene expression in CD4+ T cells and is associated with increased risk of colorectal cancer. Tumour Biol. 35: 7929-34 [PMID:24833093]

644. Xue CB, Feng H, Cao G, Huang T, Glenn J, Anand R, Meloni D, Zhang K, Kong L and Wang Set al.. (2011) Discovery of INCB3284, a Potent, Selective, and Orally Bioavailable hCCR2 Antagonist. ACS Med Chem Lett 2: 450-4 [PMID:24900329]

645. Xue CB, Wang A, Han Q, Zhang Y, Cao G, Feng H, Huang T, Zheng C, Xia M and Zhang Yet al.. (2011) Discovery of INCB8761/PF-4136309, a Potent, Selective, and Orally Bioavailable CCR2 Antagonist. ACS Med Chem Lett 2: 913-8 [PMID:24900280]

646. Yamada $\mathrm{Y}$, Ando F, Niino N and Shimokata H. (2002) Association of a polymorphism of the CC chemokine receptor-2 gene with bone mineral density. Genomics 80: 8-12 [PMID:12079277]

647. Yang D, Chertov O, Bykovskaia SN, Chen Q, Buffo MJ, Shogan J, Anderson M, Schröder JM, Wang JM 
and Howard OM et al.. (1999) Beta-defensins: linking innate and adaptive immunity through dendritic and T cell CCR6. Science 286: 525-8 [PMID:10521347]

648. Yang X, Lu P, Ishida Y, Kuziel WA, Fujii C and Mukaida N. (2006) Attenuated liver tumor formation in the absence of CCR2 with a concomitant reduction in the accumulation of hepatic stellate cells, macrophages and neovascularization. Int. J. Cancer 118: 335-45 [PMID:16052523]

649. Yano S, Mentaverri R, Kanuparthi D, Bandyopadhyay S, Rivera A, Brown EM and Chattopadhyay N. (2005) Functional expression of beta-chemokine receptors in osteoblasts: role of regulated upon activation, normal T cell expressed and secreted (RANTES) in osteoblasts and regulation of its secretion by osteoblasts and osteoclasts. Endocrinology 146: 2324-35 [PMID:15718270]

650. Yokoyama K, Ishikawa N, Igarashi S, Kawano N, Masuda N, Hamaguchi W, Yamasaki S, Koganemaru Y, Hattori K and Miyazaki T et al.. (2009) Potent and orally bioavailable CCR4 antagonists: Synthesis and structure-activity relationship study of 2-aminoquinazolines. Bioorg. Med. Chem. 17: 64-73 [PMID:19081254]

651. Yoshida R, Imai T, Hieshima K, Kusuda J, Baba M, Kitaura M, Nishimura M, Kakizaki M, Nomiyama H and Yoshie O. (1997) Molecular cloning of a novel human CC chemokine EBI1-ligand chemokine that is a specific functional ligand for EBI1, CCR7. J. Biol. Chem. 272: 13803-9 [PMID:9153236]

652. Yoshida R, Nagira M, Kitaura M, Imagawa N, Imai T and Yoshie O. (1998) Secondary lymphoid-tissue chemokine is a functional ligand for the CC chemokine receptor CCR7. J Biol Chem 273: 7118-7122 [PMID:9507024]

653. Yoshida T, Imai T, Kakizaki M, Nishimura M, Takagi S and Yoshie O. (1998) Identification of single C motif-1/lymphotactin receptor XCR1. J. Biol. Chem. 273: 16551-4 [PMID:9632725]

654. Yoshida T, Izawa D, Nakayama T, Nakahara K, Kakizaki M, Imai T, Suzuki R, Miyasaka M and Yoshie O. (1999) Molecular cloning of $m X C R 1$, the murine SCM-1/lymphotactin receptor. FEBS Lett. 458: 37-40 [PMID:10518929]

655. Yoshimura T and Oppenheim JJ. (2008) Chemerin reveals its chimeric nature.J. Exp. Med. 205: 2187-90 [PMID:18809717]

656. Youn BS, Kim CH, Smith FO and Broxmeyer HE. (1999) TECK, an efficacious chemoattractant for human thymocytes, uses GPR-9-6/CCR9 as a specific receptor. Blood 94: 2533-6 [PMID:10498628]

657. Yu CR, Peden KW, Zaitseva MB, Golding H and Farber JM. (2000) CCR9A and CCR9B: two receptors for the chemokine CCL25/TECK/Ck beta-15 that differ in their sensitivities to ligand. J. Immunol. 164: 1293305 [PMID:10640743]

658. Yu L, Cecil J, Peng SB, Schrementi J, Kovacevic S, Paul D, Su EW and Wang J. (2006) Identification and expression of novel isoforms of human stromal cell-derived factor 1. Gene 374: 174-9 [PMID:16626895]

659. Zaballos A, Gutiérrez J, Varona R, Ardavín C and Márquez G. (1999) Cutting edge: identification of the orphan chemokine receptor GPR-9-6 as CCR9, the receptor for the chemokine TECK. J. Immunol. 162: 5671-5 [PMID:10229797]

660. Zaballos A, Varona R, Gutierrez J, Lind P and Marquez G. (1996) Molecular cloning and RNA expression of two new human chemokine receptor-like genes. Biochem Biophys Res Commun227: 846-853 [PMID:8886020]

661. Zabel BA, Agace WW, Campbell JJ, Heath HM, Parent D, Roberts Al, Ebert EC, Kassam N, Qin S, Zovko M, LaRosa GJ, Yang LL, Soler D, Butcher EC, Ponath PD, Parker CM and Andrew DP. (1999) Human G protein-coupled receptor GPR-9-6/CC chemokine receptor 9 is selectively expressed on intestinal homing T lymphocytes, mucosal lymphocytes, and thymocytes and is required for thymus-expressed chemokinemediated chemotaxis. J. Exp. Med. 190: 1241-1256 [PMID:10544196]

662. Zabel BA, Allen SJ, Kulig P, Allen JA, Cichy J, Handel TM and Butcher EC. (2005) Chemerin activation by serine proteases of the coagulation, fibrinolytic, and inflammatory cascades. J. Biol. Chem. 280: 34661-6 [PMID:16096270]

663. Zabel BA, Nakae S, Zúñiga L, Kim JY, Ohyama T, Alt C, Pan J, Suto H, Soler D, Allen SJ, Handel TM, Song CH, Galli SJ and Butcher EC. (2008) Mast cell-expressed orphan receptor CCRL2 binds chemerin and is required for optimal induction of IgE-mediated passive cutaneous anaphylaxis. J. Exp. Med. 205: 2207-20 [PMID:18794339]

664. Zabel BA, Wang Y, Lewén S, Berahovich RD, Penfold ME, Zhang P, Powers J, Summers BC, Miao Z, Zhao B, Jalili A, Janowska-Wieczorek A, Jaen JC and Schall TJ. (2009) Elucidation of CXCR7-mediated signaling events and inhibition of CXCR4-mediated tumor cell transendothelial migration by CXCR7 ligands. J. Immunol. 183: 3204-11 [PMID:19641136]

665. Zafiropoulos A, Crikas N, Passam AM and Spandidos DA. (2004) Significant involvement of CCR2-64I and CXCL12-3a in the development of sporadic breast cancer. J. Med. Genet. 41: e59 [PMID:15121787]

666. Zamarchi R, Allavena P, Borsetti A, Stievano L, Tosello V, Marcato N, Esposito G, Roni V, Paganin C and 
Bianchi G et al.. (2002) Expression and functional activity of CXCR-4 and CCR-5 chemokine receptors in human thymocytes. Clin. Exp. Immunol. 127: 321-30 [PMID:11876757]

667. Zernecke A, Weber KS, Erwig LP, Kluth DC, Schröppel B, Rees AJ and Weber C. (2001) Combinatorial model of chemokine involvement in glomerular monocyte recruitment: role of CXC chemokine receptor 2 in infiltration during nephrotoxic nephritis. J. Immunol. 166: 5755-62 [PMID:11313419]

668. Zhang H, Kang D, Huang B, Liu N, Zhao F, Zhan P and Liu X. (2016) Discovery of non-peptide small molecular CXCR4 antagonists as anti-HIV agents: Recent advances and future opportunities. Eur $\mathrm{J}$ Med Chem 114: 65-78 [PMID:26974376]

669. Zhang WB, Navenot JM, Haribabu B, Tamamura H, Hiramatu K, Omagari A, Pei G, Manfredi JP, Fujii N, Broach JR and Peiper SC. (2002) A point mutation that confers constitutive activity to CXCR4 reveals that T140 is an inverse agonist and that AMD3100 and ALX40-4C are weak partial agonists. J Biol Chem 277: 24515-24521 [PMID:11923301]

670. Zhang Z, Cherryholmes G, Chang F, Rose DM, Schraufstatter I and Shively JE. (2009) Evidence that cathelicidin peptide LL-37 may act as a functional ligand for CXCR2 on human neutrophils. Eur. J. Immunol. 39: 3181-94 [PMID:19750480]

671. Zhao J, Ma L, Wu YL, Wang P, Hu W and Pei G. (1998) Chemokine receptor CCR5 functionally couples to inhibitory $G$ proteins and undergoes desensitization. J Cell Biochem 71: 36-45 [PMID:9736452]

672. Zheng Y, Qin L, Zacarías NV, de Vries H, Han GW, Gustavsson M, Dabros M, Zhao C, Cherney RJ and Carter P et al.. (2016) Structure of CC chemokine receptor 2 with orthosteric and allosteric antagonists. Nature 540: 458-461 [PMID:27926736]

673. Zhou Y, Kurihara T, Ryseck RP, Yang Y, Ryan C, Loy J, Warr G and Bravo R. (1998) Impaired macrophage function and enhanced $T$ cell-dependent immune response in mice lacking CCR5, the mouse homologue of the major HIV-1 coreceptor. J. Immunol. 160: 4018-25 [PMID:9558111]

674. Zlotnik A, Morales J and Hedrick JA. (1999) Recent advances in chemokines and chemokine receptors. Crit. Rev. Immunol. 19: 1-47 [PMID:9987599]

675. Zlotnik A and Yoshie O. (2000) Chemokines: a new classification system and their role in immunity. Immunity 12: 121-7 [PMID:10714678]

676. Zoffmann S, Turcatti G, Galzi J, Dahl M and Chollet A. (2001) Synthesis and characterization of fluorescent and photoactivatable MIP-1alpha ligands and interactions with chemokine receptors CCR1 and CCR5. J. Med. Chem. 44: 215-22 [PMID:11170631]

677. Zou D, Dasse O, Evans J, Higgins P, Kintigh J, Kondru R, Schwartz E, Knerr L and Zhai H-X. (2005) Pyrrolidinone derivatives Patent number: US6936633.

678. Zou YR, Kottmann AH, Kuroda M, Taniuchi I and Littman DR. (1998) Function of the chemokine receptor CXCR4 in haematopoiesis and in cerebellar development. Nature 393: 595-9 [PMID:9634238]

679. Zuurman MW, Heeroma J, Brouwer N, Boddeke HW and Biber K. (2003) LPS-induced expression of a novel chemokine receptor (L-CCR) in mouse glial cells in vitro and in vivo. Glia 41: 327-36 [PMID:12555200] 